EISSN: 2706-7939 ISSN: 2077-4508

DOI: 10.36632/ije/2021.10.3.11

Journal homepage: www.curresweb.com

Pages: 109-172

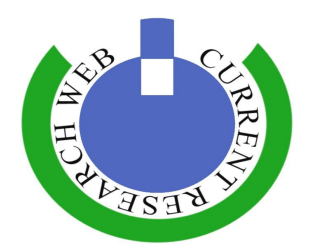

\title{
The Environmental Applicability of Vermicompost for Developing and composting organic wastes to control the risk of adverse impacts on the Environment
}

\author{
${ }^{1}$ Abou Seeda M.A., ${ }^{2}$ Abou El-Nour E.A.A, ${ }^{1}$ Yassen A.A. and ${ }^{1}$ Sahar M. Zaghloul
}

${ }^{1}$ Plant Nutrition Dept., ${ }^{2}$ Fertilization Tech. Dept., National Research Centre, 33 El Buhouth St., 12622 Dokki, Giza, Egypt.

Received: 15 June $2021 \quad$ Accepted: 10 July $2021 \quad$ Published: 20 July 2021

ABSTRACT

Environmental contamination due to solid waste mismanagement is a global issue. Open dumping and open burning are the main implemented waste treatment and final disposal systems, mainly visible in low-income countries. The environmental impacts are pervasive worldwide: marine litter, air, soil and water contamination, and the direct interaction of waste pickers with hazardous waste are the most important issues. This narrative literature review assessed global issues due to different waste fractions showing how several sources of pollution are affecting the environment, population health, and sustainable development. Urbanization and industrialization resulted in rapid increase in volume of solid waste; its management has become one of the biggest problems today. Solid wastes can be disposed of by methods like land filling, incineration, conversion into biogas, recycling, and composting, but its overproduction has led to in appropriate disposal practices such as their indiscriminate and in appropriately timed application to agricultural fields that ultimately leads to water and soil pollution. However, organic wastes can be used for vermicomposting; it is an effective recycling technology that improves the quality of the products that is disinfected, detoxified, and highly nutritive. Because of non-thermophilic, boioxidative process that involves earthworms and associated microbes. This biological organic waste decomposition process yields the biofertilizer namely the vermicompost. It enhances soil biodiversity by promoting the beneficial microbes that in turn enhances plant growth directly by production of plant growth-regulating hormones and enzymes and indirectly by controlling plant pathogens, nematodes and other pests, thereby enhancing plant health and minimizing the yield loss. It is a low cost, eco-biotechnological process in which earthworms are used to cooperate with microorganisms in order to convert biodegradable wastes into organic fertilizer.

Vermicompost is beneficial for sustainable organic agriculture and maintaining balanced ecosystem.

Keywords: Environmental Applicability, Organic waste, Vermicompost, Bacterial Communities, Earthworms, Plant Growth Promoters, Biocontrol, Microbial Diversity

\section{Introduction}

Solid waste (SW) mismanagement is a global issue in terms of environmental contamination, social inclusion, and economic sustainability Gupta, et al., (2015) Vitorino de Souza Melaré et al., (2017), which requires integrated assessments and holistic approaches for its solution Bing, et al., (2016). Attention should be paid in developing and transition countries, where the unsustainable management of SW is common The World Bank (2012). Differences should be highlighted between developing big cities and rural areas, where management issues are different, specifically regarding the amount of waste generated and the SW management (SWM) facilities available Ferronato, et al., (2019) Fig. (1). However, both suffer negative economic legislatives, political, technical and operational limitations Imam, et al., (2008). Uncontrolled disposal generates serious heavy metals pollution occurring in the water, soil, and plants Vongdala, et al., (2019),open burning is cause of CO, CO2, SO, NO, PM10 and other pollutant emissions that affect the atmosphere Wiedinmyer, et al., (2014) Fig. (2). Therefore, SW mismanagement is cause of sever and various environmental and social impacts, which do not allow improvements in sustainable development Fig. (3).

Corresponding Author: Abou Seeda M.A., Plant Nutrition Dept., National Research Centre, 33 El Buhouth St., 12622 Dokki, Giza, Egypt. E-mail: mabouseeda@gmail.com 

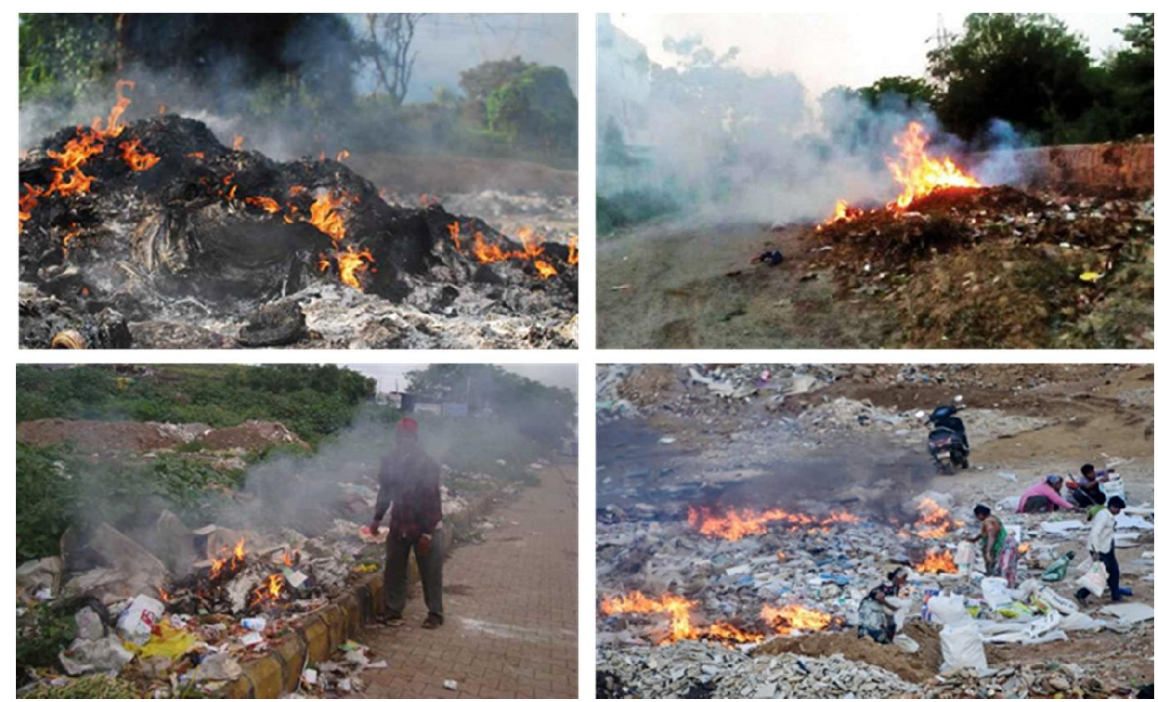

Fig. 1: Represents Open burning of solid wastes causing emissions of $\mathrm{CO}, \mathrm{CO}_{2}, \mathrm{SO}, \mathrm{NO}, \mathrm{PM} 10$ and Other pollutant
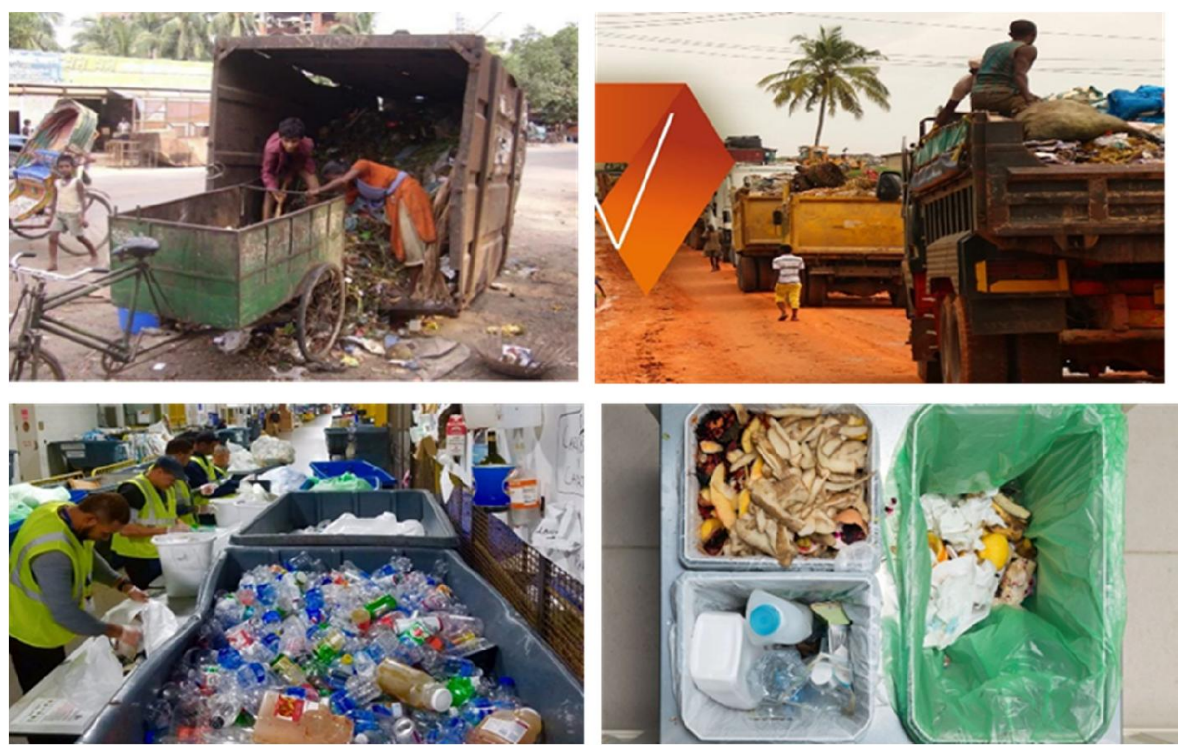

Fig. 2: Illustrates different handling of solid wastes in developed and developing countries 

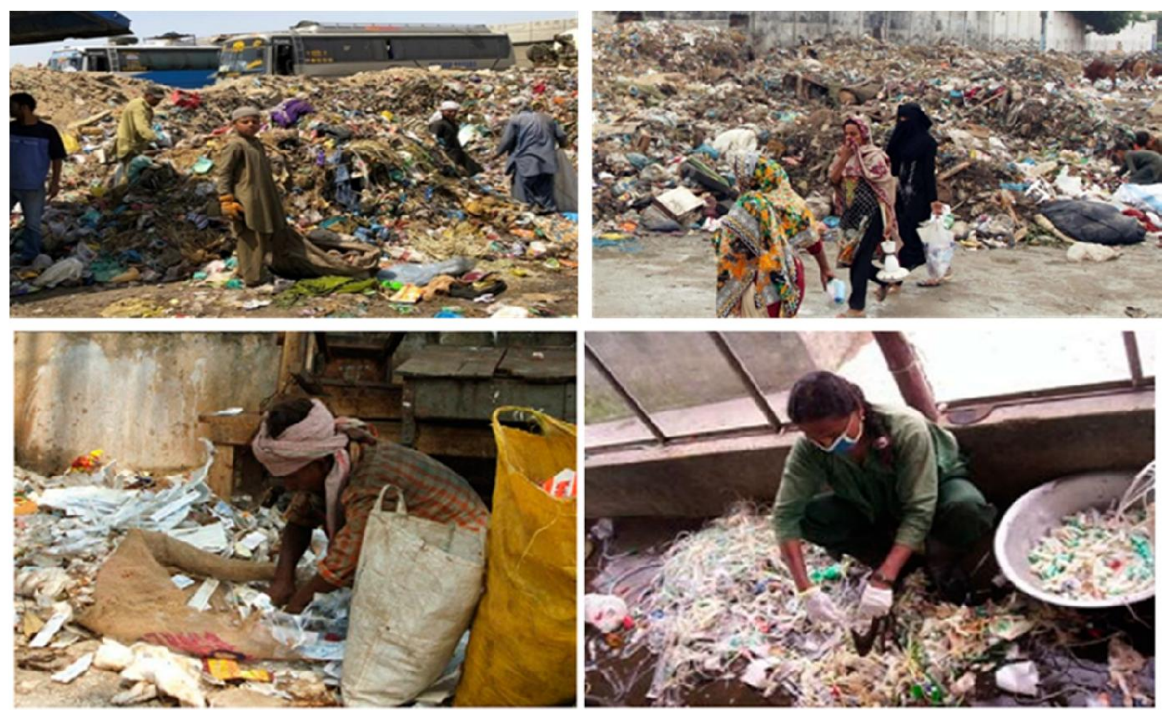

Fig. 3: Represents solid waste mismanagement is causing of sever and various environmental and social impacts generates serious heavy metals pollution occurring in the water, soil, and plants

Many studies reported possible solutions for improving the SWM in developing countries, such as organic waste buyback programs Fig. (4), as well as biogas projects Fig. (5).

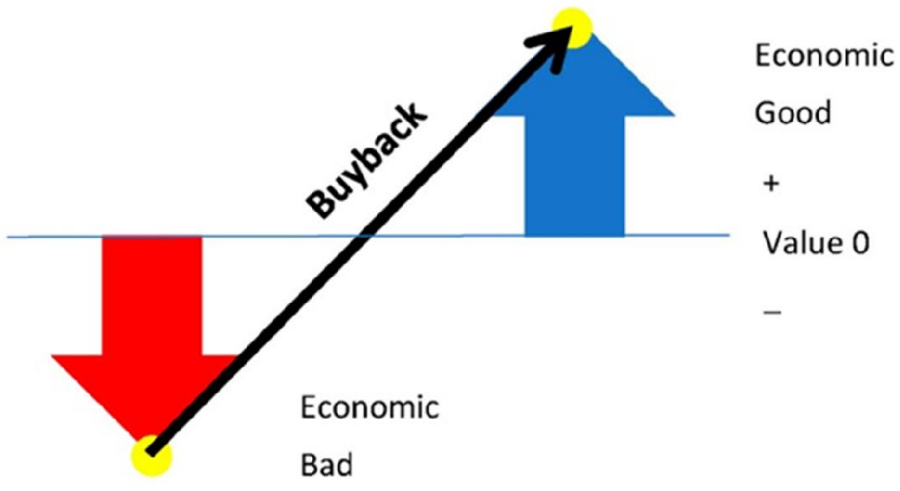

Fig. 4: Illustrates Buyback proposition can change the value of organic waste. After Hettiarachchi et al., (2018)

Hettiarachchi et al., (2018) reported that from the economics standpoint, organic waste buyback changes the value proposition of waste by turning it from an economic bad to an economic good Fig. (4). Economic bad, which is the opposite concept of an economic good, refers to something with a negative value to people or a negative price in the market. Economic good, on the other hand, means something that has utility and provides positive value to people. Economic bads and goods are not absolute concepts but subjective ideas that may change according to perception. Organic waste itself is an economic bad because it creates problems when not managed properly. However, for proper management with treatment, someone, often a municipality, must pay a higher price. However, a buyback system modifies people's recognition of organic waste by returning some financial incentives. With buyback systems, people will perceive organic waste as a good with a market price and will be eager to have it for their own benefit with compost or biogas production Hettiarachchi, et al., (2018), implementation of waste-to-energy plans and technologies Ouda, et al., (2016) Fig.(5). They also stated that Hettiarachchi et al., (2020), stated that many developing countries have inadequate Municipal Solid Waste (MSW) management systems due to lack of not only the awareness, technologies, finances, but also a proper governance that is able to enforce and monitor the regulations. Not all the solutions 
practiced by and in developed countries fit to the developing country contexts. The local conditions and limitations must always be taken into account when proposing waste management options for developing countries. The excessively high organic waste fraction in MSW and relatively inexpensive labor markets available in developing countries are two of the strengths that have not yet been utilized fully. This manuscript is an attempt to point out the benefits we receive from the above two strengths if we establish organic waste buyback programs. This can only become successful if we find solutions to: (1) collect source-separated organic waste, and then (2) find stable markets for the products made from organic waste. Compost or biogas could be the best developing countries can consider as products. However, there must be some policy interventions to support buyback programs at the waste collection stage as well as at the product marketing stage. Implementation of such organic waste buyback centers that can offer some incentives can indirectly motivate residents to do source separation. This will in turn also help promote more recycling, as any waste bin that has no organics in it is much easier for anyone (e.g., waste pickers) to look for other recyclables. Developing country settings such as the Green Container composting program in Cajicá, Colombia, and buyback centers in South Africa that are presented later in the manuscript are thought to be the places where the concept can be implemented with little effort. The environment, economy, and society are considered to be the three dimensions (or pillars) of sustainability. Interestingly, the organic waste buyback centers solution has positive implications on all three aspects of sustainability. Thus, it also supports the 2030 Agenda of the United Nations (UN), by making specific contributions to the Sustainable Development Goals (SDGs) such as zero hunger (SDG 2), affordable and clean energy (SDG 7), climate action (SDG 13), clean water and sanitation (SDG 6), and sustainable cities and communities (SDG 11).Therefore, environmental contamination remains a big issue worldwide, while common solutions should be identified and implemented considering SWM patterns appropriate for each context.
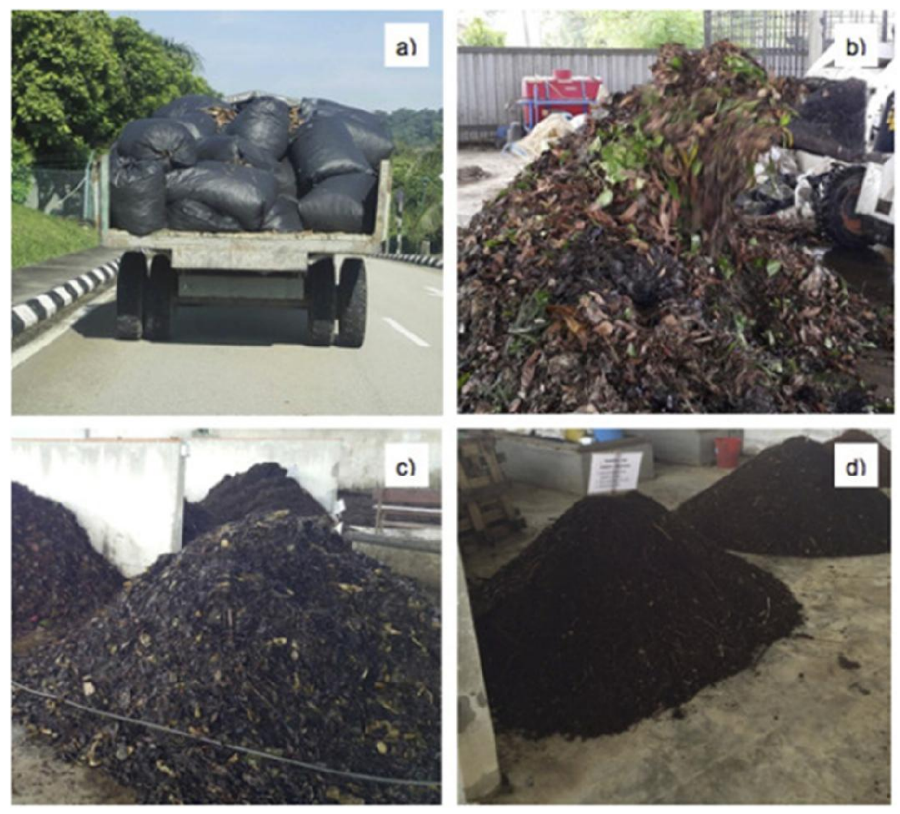

Fig. 5: Represents Yard waste composting activities in MARDI, Serdang, and Selangor, Malaysia. (a) Yard waste collected weekly in large plastic bags transported to the compost processing facility; (b) Mixture of yard waste with $\mathrm{N}$ sources (mostly livestock manure) at the beginning of composting; (c) Compost heap within 35 days; (d) Compost heap at the end of the process. After Abdul Rahman et al., (2020)

Abdul Rahman et al., (2020) they stated that composting of yard waste is one of the waste management approaches in the Malaysian Agricultural Research and Development Institute (MARDI) in Serdang, Selangor, Malaysia. The yard waste inventory was developed in the headquarters' area and a pilot-scale study was performed on the potential compost product. The total amount of yard waste 
generated from June 2017 to December 2017 was 16.75 tonnes with an average generation of 0.60 tonnes per week on the fresh weight (f.w.) basis. The collected yard waste consisted of three major characteristics, namely dry leaves, fresh green leaves, and grass cuttings, and a waste estimation technique was applied to determine the composition of these three elements. The acquired information was used to formulate the initial compost mixture. The wastes were then mixed with an appropriate amount of livestock manure and other wastes to obtain the optimum initial $\mathrm{C} / \mathrm{N}$ ratio, which was then found in the analysis to range between 25:1 and 42:1. Meanwhile, the $\mathrm{C} / \mathrm{N}$ ratios obtained from the matured compost product were from 10:1 and 15:1. Moreover, most of the compost yield ranged between $50 \%$ and $70 \%\left(\mathrm{w} \mathrm{w}^{-1} \mathrm{~d} . \mathrm{w}\right.$. basis), while the percentage of the seed germination in the compost was over $95 \%$. The viability of the project was indicated from the economic analysis, with benefit to cost ratio (BCR) values of more than 1 . The results also suggested that the large scale composting of yard waste in MARDI was feasible and its applicability is continuous. This technique also fulfilled the objective of producing quality compost, which was suitable for agricultural use.

Increasing world population resulted in higher consumption of goods and services that has driven a substantial increase of organic wastes originating from households, industry, and agriculture Hoornweg et al., (2013). Much of the organic wastes are highly infectious as they contain a variety of pathogenic microorganisms. Dumping of organic wastes in open areas generates serious environmental issues such as the accumulation of heavy metals in soil, pollution of ground and surface waters due to leaching and run-off of nutrients. These organic wastes when applied directly to agricultural fields cause soil environment-related problems including phytotoxicity Hsu and Lo (1999). These wastes represent a valuable organic resource, which could be recycled and transformed into nutrient rich fertilizer and/or soil conditioner Marshall, and Farahbakhsh (2013), Bernstad et al., (2016), Calabi-Floody et al., (2018). Moreover, growing awareness about adverse effects of agricultural chemicals on human health has increased interest in organic agriculture Sinha and Chan (2009).Organic agriculture promotes ecological conservation due to judicious use of natural resources Reganold et al., (1993), Mader et al., (2002). In demand for safe and sustainable strategies to treat organic wastes includes best-known practices of composting and vermicomposting for biological stabilization of solid organic wastes by transforming them into a safer and more stabilized material that used as a source of nutrients and soil conditioner in agricultural applications Lazcano et al., (2008), Dominguez and Edwards (2010) Fig. (6).

Vermicomposting is one of the most efficient means to mitigate and manage environmental pollution problems Waleed (2016). Recently, many studies are being done to establish vermicompost as one of the preferred organic substitutes to chemical fertilizers Sinha et al., (2009), Adhikary (2012). Vermicompost is richer in NPK, micronutrients and beneficial soil microbes (nitrogen fixing and phosphate solubilizing bacteria and actinomycetes), an excellent growth promoter and protector for crop plants Sinha et al., (2011), Chauhan et al., (2015), than compost Maulini-Duran et al., (2014), Cerda et al., (2017). Earthworms excreta (vermicast) is a nutritive organic fertilizer rich in humus, NPK, micronutrients, beneficial soil microbes; nitrogen-fixing, phosphate solubilizing bacteria, actinomycets, and growth hormones auxins, gibberlins and cytokinins, is a suitable alternative to chemical fertilizers, being an excellent growth promoter and protector for crop plants. Thus, vermiculture not only results in management of soild waste but also produces excellent nutrient enriched vermicompost Fig. (7).

Soil bacteria such as bacillus, pseudomonas and Streptomyces etc., are prolific producers of secondary metabolites that act against numerous co-existing phytopathogenic fungi and human pathogenic bacteria Pathma et al., (2011b). Earthworms are popularly known as the "farmer's friend" or "nature's plowman". Earthworm influences microbial community, physical and chemical properties of soil. They breakdown large soil particles and leaf litter and thereby increase the availability of organic matter for microbial degradation and transforms organic wastes into valuable vermicompost by grinding and digesting them with the help of aerobic and anaerobic microbes Maboeta and Van Rensburg (2003). Earthworms' activity is found to enhance the beneficial microflora and suppress harmful pathogenic microbes. Soil wormcasts are rich source of micro and macronutrients, and microbial enzymes Lavelle and Martin (1992) Fig. (8).

Medina-Sauza et al., (2019) stated that physiology, morphology and behaviour of earthworms is essential to understand their effect on soil functions Fig. 8, arrow 1). However, there is increasing evidence that the effect of earthworms on soil functions may be mediated through soil microbial communities Fig. 8, arrow 2). It is yet not clear how the different ecological groups may promote or select soil microorganisms and there are many contradictory results concerning the effect of earthworms 
on soil microbial communities Byzov et al., (2015). However, the drilosphere is generally acknowledged as being a soil hotspot with a positive effect on ecosystem functions such as nutrient cycling and plant growth Brown et al., (1999); Scheu, (2003); Van Groenigen et al., (2014). Considering that the involvement of microorganisms in these functions is fundamental, it is therefore necessary to consider microbial communities and how they are influenced by earthworms in order to understand and predict the effect of earthworms on ecosystem functions. It is our hypothesis that "the effect of earthworms on nutrient cycling and plant growth is not only a direct effect but is mainly mediated indirectly, via modifications of the microbial community" Fig. (8). Thus, the objectives of this review are two. The first is to determine whether some patterns can be drawn from the existing literature regarding the effect of the different earthworm functional groups (epigeic, endogeic, and anecic) on the abundance, structure and diversity of soil microorganisms (bacteria, archae, and fungi) at the different sites (earthworm gut, casts, burrows, bulk soil, rhizosphere, others). The analytical methods used are also considered [Gram $+/-$, fingerprinting, phospholipid fatty acids (PLFA), sequencing]. The second is to establish the impact of earthworms on microbial processes involved in nutrient cycling, on the production of signal molecules and as a consequence, on plant growth promotion.

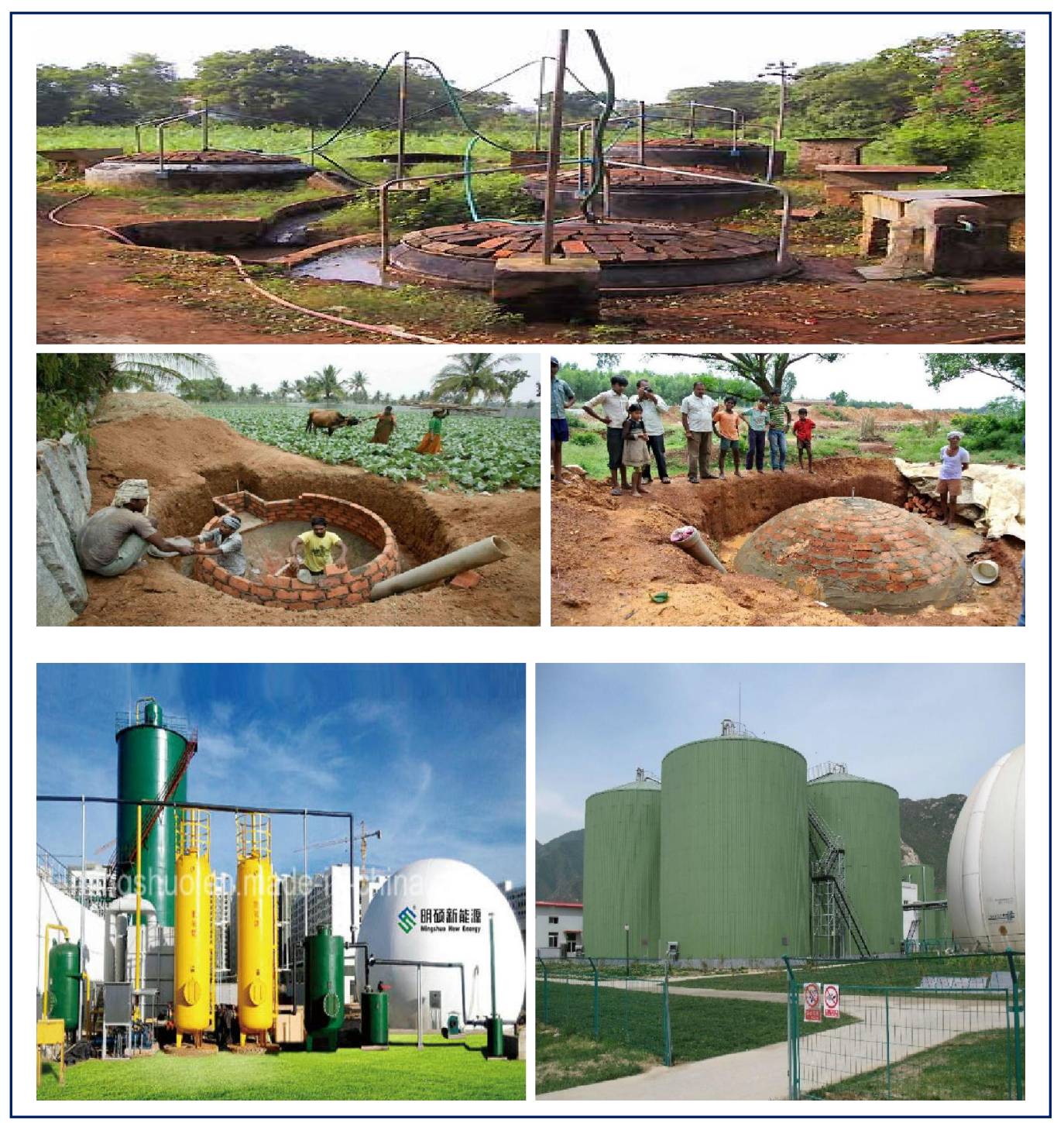

Fig. 6: Illustrates a Project information of biogas plant in developing country (India) and developed at a chicken and cow farm in china (Bejing) 

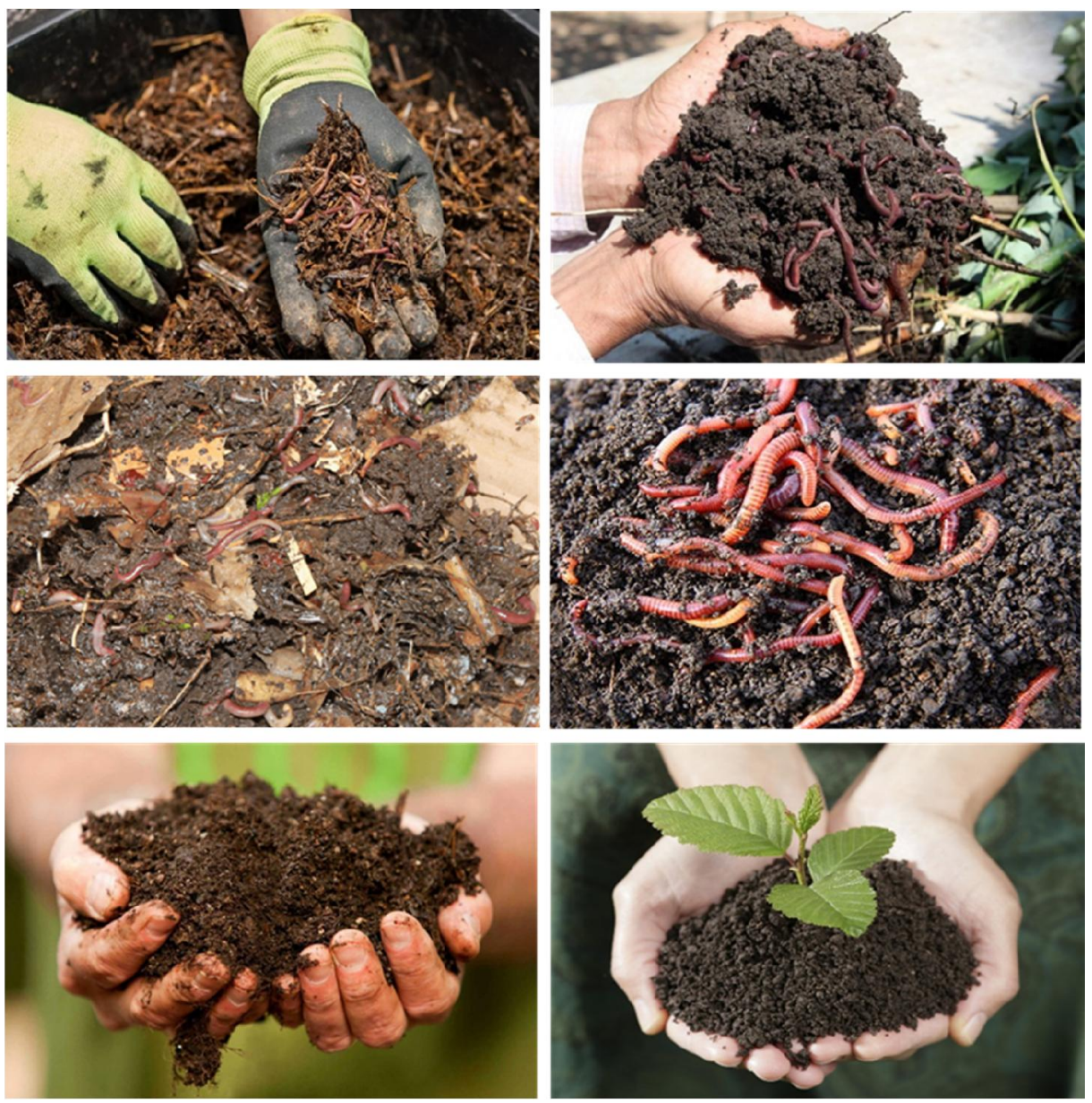

Fig. 7: Illustrates Earthworm used decomposable organic wastes as their food, from which the body cell of the earthworm and the rest of their food absorb about 5 to 10 percent of the consumed food is excreted in the form of pellets that is known as Vermi- compost.

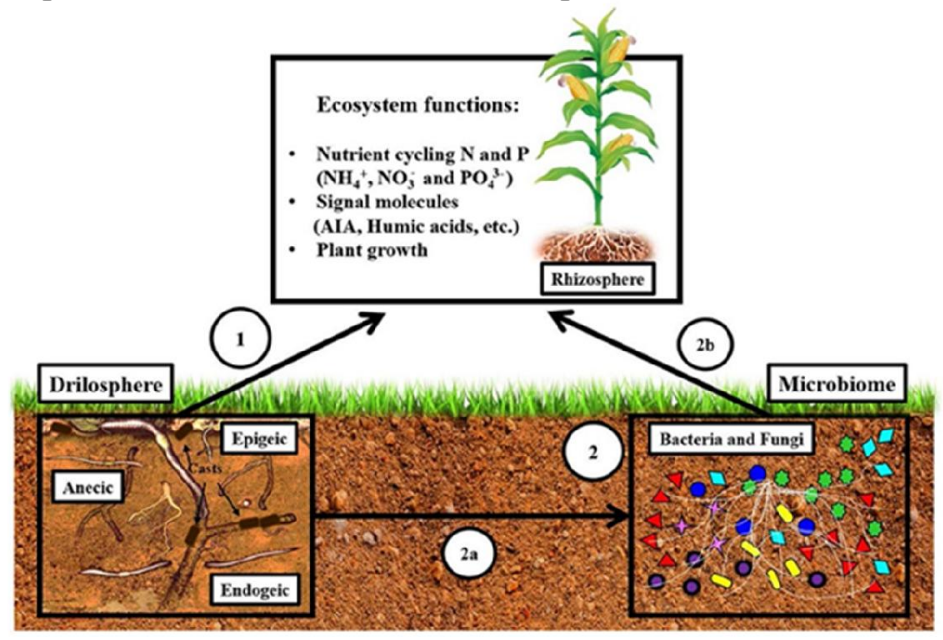

Fig. 8: Represents the hypothesis effect of earthworms on nutrient cycling and plant growth is not only a direct effect but also microorganisms mainly mediate it indirectly. The impact of earthworms is direct (1), or indirect, through the stimulation of microorganisms (2). By modifying microbial communities (2a), earthworms affect the way bacteria are influencing ecosystem functions (2b). This figure aims at illustrating the fact that indirect effects are as important as direct ones. After Medina-Sauza et al., (2019) 
Medina-Sauza et al., (2019) The capacity of earthworms to decompose organic matter has been attributed to the microbial communities that inhabit their digestive track or the structures they build, which in turn contribute to make up the drilosphere, a hotspot for microbial activity. However, how earthworms modify the structure of soil microbial communities and how these changes affect soil microbial processes is still unclear. The effect of earthworms on nutrient cycling and plant growth is not only a direct effect but is mainly mediated indirectly, via modifications of the microbial community. Recent reports have shown that specific bacterial groups consistently increase in soils where earthworms are present, regardless of the earthworm functional group. The extent of this increase seems to be dependent upon the type of substrate under study. They also reveals that endogeic and anecic earthworms regularly induce an increase in soil nutrients, whilst this positive effect is not as evident in the presence of epigeic earthworms. The effect of earthworms on nutrient cycling has been further investigated with microbial functional genes, although existing reports largely focus on nitrogen cycling. Earthworms seem to enhance denitrification, most likely through the increase in organic compounds due to organic matter decomposition. By enhancing soil nutrient availability, earthworms indirectly promote plant growth, which has also been attributed to the induction of signal molecules. Finally, we propose a framework for earthworm-microbiota interactions and recommend further research. Vermicomposting is an efficient nutrient recycling process that involves harnessing earthworms as versatile natural bioreactors for organic matter decomposition. Due to richness in nutrient availability and microbial activity, vermicompost increase soil fertility, enhance plant growth and suppress the population of plant pathogens and pests. This review paper describes the bacterial biodiversity and nutrient status of vermicompost and their importance in agriculture and waste management.

\section{1- Vermicomposting- a preferred approach in organic farming}

Vermicomposting is a mesophilic process Edwards and Burrows (1988), that involves a joint action of earthworms (active at $10-32^{\circ} \mathrm{C}$ ) and mesophilic microbes Benitez et al., (1999), for the conversion of organic wastes into a valuable product known as vermicompost. Whereas, composting involves the degradation of organic waste by microorganisms under controlled conditions, in which the organic material undergoes a characteristic thermophilic stage that allows sanitization of the waste by elimination of pathogenic microorganisms Lung et al., (2001). Composting is also used to treat manures, green wastes or municipal solid wastes Goyal et al., (2005). However, vermicomposting gives a higher-quality product than composting due to joint action of enzymatic and microbial activities that occur during the process Bajsa et al., (2003). This process is faster than traditional composting as the material passes through the earthworm gut, whereby the resulting earthworm castings are rich in microbial activity and plant growth regulators, and fortified with pest repellence attributes as well Vermi (2020), Crescent (2003) Fig. (9). Compared to traditional composting method, vermicomposting also results in mass reduction, shorter processing time, and high levels of humus with reduced phytotoxicity Atiyeh et al., (2001).Thus, vermicompost is considered an ideal manure for organic agriculture as it is nutrient rich and contains high quality humus, plant growth hormones, enzymes, and substances that are able to protect crops against pests and diseases Sinha et al., (2010), Sinha et al., (2010).

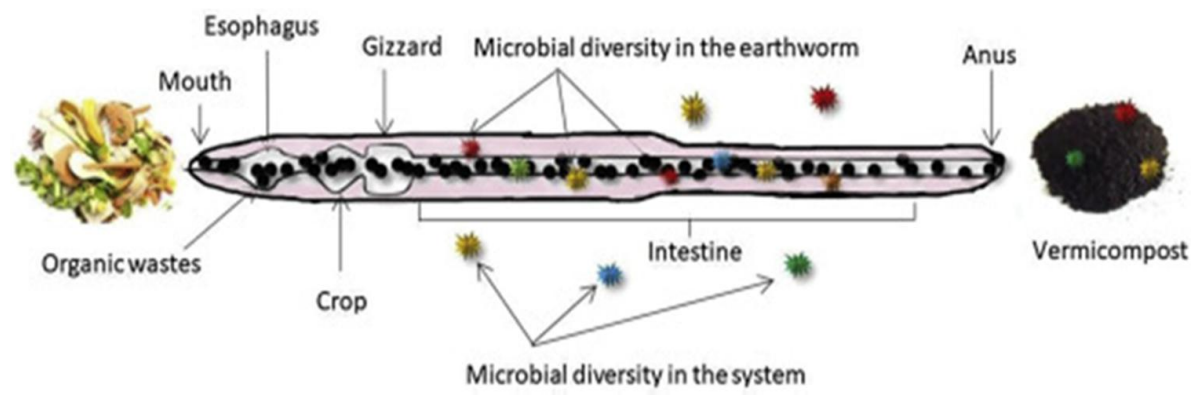

Fig. 9: Illustrates the interaction between earthworm and microorganisms in earthworm's gut. 
Moreover, vermicompost has high porosity, aeration, drainage, and water-holding capacity Edwards and Burrows (1988).In addition to increased $\mathrm{N}$ availability, C, P, K, Ca and Mg plant nutrient availability in the earthworm casts are also found Orozco et al., (1996). Plants growth hormones namely cytokinins and auxins are found in organic wastes processed by earthworms Orozco et al., (1996).They also release certain metabolites, such as vitamin B, vitamin D and similar substances into the compost Krishnamoorthy and Vajrabhiah (1986). Thus, earthworms accelerate the mineralization rate and convert the manures into casts with higher nutritional value and degree of humification than traditional method of composting Jeyabal et al., (2001) Fig. (10).

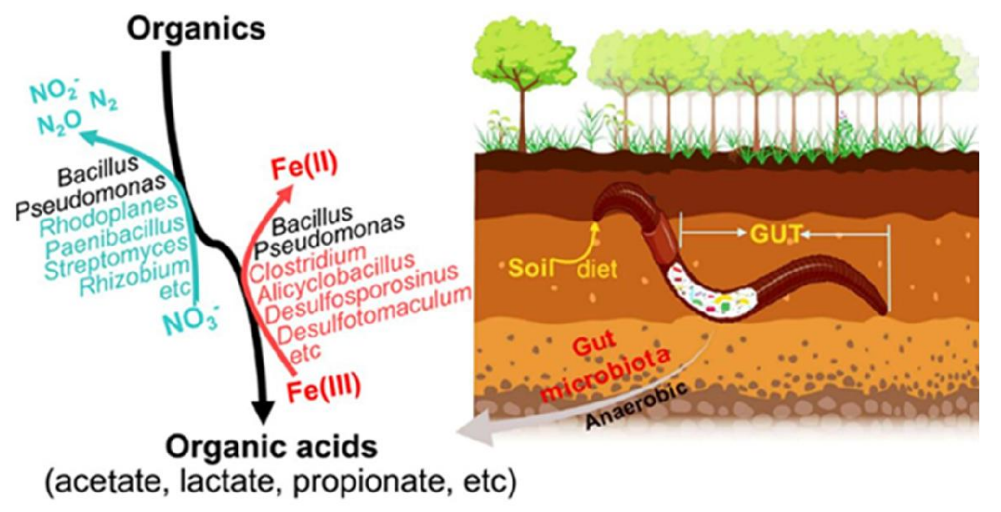

Fig. 10: Illustrates the diagram of iron $\mathrm{Fe}^{+3}$ reduction and its interaction with denitrification in the gut of earthworm Pheretima guillelmi

The composition of commonly available nutrients in vermicompost is as follows: Organic carbon 9.5-17.98\%, Nitrogen 0.5-1.50\%, Phosphorous $0.1-0.30 \%$, Potassium $0.15-0.56 \%$, Sodium 0.06$0.30 \%$, Calcium and Magnesium 22.67-47.60 meq $/ 100 \mathrm{~g}$, Copper $2-9.50 \mathrm{mg} / \mathrm{kg}$, Iron 2-9.30 mg/ kg, Zinc $5.70-11.50 \mathrm{mg} / \mathrm{kg}$, Sulfur $128-548 \mathrm{mg} / \mathrm{kg}$ Kale (1995). Hence, vermicomposting enables biological transformation of wastes into a valuable organic fertilizer Bozym (2012), Kostecka (2000).Vermicompost is popularly called as black gold and has become one of the major components of organic farming system Crescent (2003).

Earthworms are considered as ecosystem engineers that play an important role in shaping soil structure and cycling nutrients Blouin et al., (2013) Fig. (11).
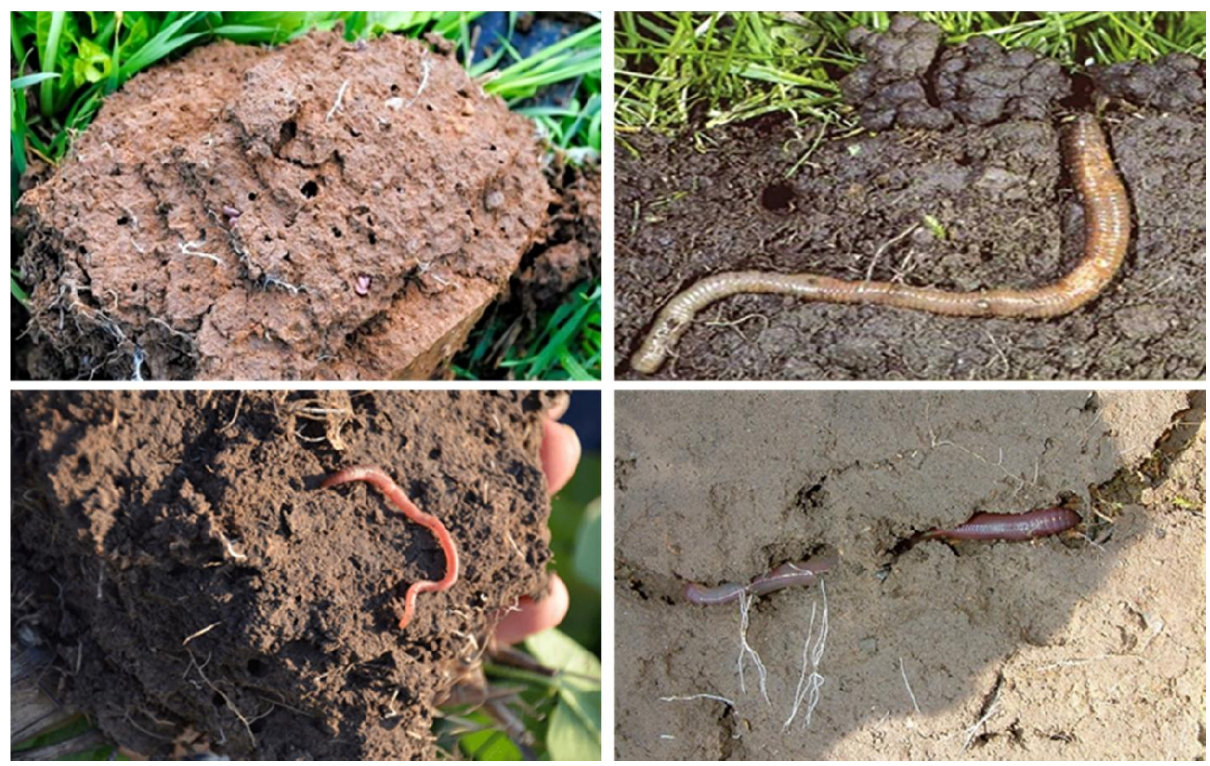

Fig. 11: Illustrates Earthworms stimulate the physical characteristics of the soil 
Earthworms promote litter decomposition, nitrogen $(\mathrm{N})$ mineralization and water infiltration, because of their feeding and burrowing habits Baker, (2007), and therefore deeply affect soil properties Hättenschwiler and Gasser, (2005). They also play a crucial role in the provision of soil ecosystem services Lavelle et al., (2016). The soil volume directly influenced by earthworms, known as the drilosphere Bouché, (1977); Lavelle, (2002), is an important functional region of the soil, made by the earthworm community and the structures it creates: middens, burrows, tunnels, and casts. Earthworms are thus builders of habitats for other organisms, which establishes them as physical or allogenic engineers Jones et al., (1994); Lavelle et al., (1997), (2016). Besides, these building activities constitute an input of organic matter to the soil and a pathway for the stabilization of soil organic carbon (C-org) through the formation of organomineral aggregates Deeb et al., (2017). This enrichment in organic matter mainly results from earthworm food choice Curry and Schmidt, (2007), its digestion and excretion of intestinal or cutaneous mucus that can be cementing Shipitalo and Le Bayon, (2004) or used as an energy source Lavelle et al., (1995). In addition to shaping soil structure, earthworms also have an important impact on soil organic matter dynamics and microorganisms in their gut, casts and drilosphere Andriuzzi et al., (2016) and are identified as biochemical Lavelle et al., (2016) or autogenic ecosystem engineers Lawton and Jones, (1995). Earthworms are divided into three main functional groups or ecological categories, which determines how they influence the soil compartment and its microbial communities Thakuria et al., (2010); Fig. (12)

(a) Epigeic earthworms live on the soil surface and feed from the litter.

(b) Endogeic earthworms live in the soil and produce horizontal tunnels, while feeding on mineral soil and partially decomposed material, being then geophagous.

(c) Anecic earthworms produce permanent vertical burrows and feed on the Litter that they drag into their burrows to be pre-decomposed by microorganisms while depositing their casts at the burrow entrance Bouché, (1977); Lavelle, 1981)(; Lee, (1985). Earthworms are considered as key ecological mediators that have the capacity to affect soil functions and microbial activities Binet et al., (1998); Lavelle et al., (2016), by producing an energy-rich mucus that activates microorganisms through a priming effect Jenkinson, (1966) and signal molecules that have hormone-like effects and influence plant gene expression Puga- Freitas and Blouin, (2015). The mutualistic interaction existing between earthworms and the soil microbiota has been named the "Sleeping Beauty Paradox" Lavelle et al., (1995); Brown et al., (2000), where dormant soil microorganisms, awaiting suitable environmental conditions are activated by the kiss of the earthworm made of easily assimilable glycoproteins present in the drilosphere in the form of intestinal or cutaneous mucus as already mentioned. This triggers the acceleration of microbial processes for a short period of time ("hot moment").

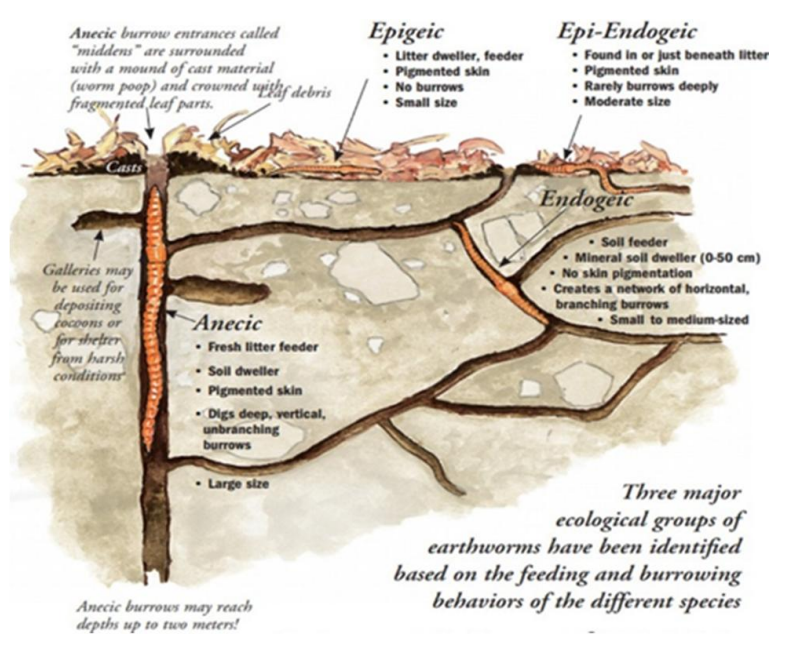

Fig. 12: Represents each functions of Earthworms in the ecosystem, Earthworms can be grouped into categories by their morphology, ecology and vertical position in (or above) the soil.

Regina et al., (2019), they reported that positive effect of earthworms on soil processes and plant growth has been extensively documented. The capacity of earthworms to decompose organic matter 
has been attributed to the microbial communities that inhabit their digestive track or the structures they build, which in turn contribute to make up the drilosphere, a hotspot for microbial activity. However, how earthworms modify the structure of soil microbial communities and how these changes affect soil microbial processes is still unclear. Do earthworms reduce microbial abundance and activity because they feed on microorganisms or do they select and stimulate specific microbial groups? We hypothesizes that "the effect of earthworms on nutrient cycling and plant growth is not only a direct effect but is mainly mediated indirectly, via modifications of the microbial community. They also reveals that endogeic and anecic earthworms regularly induce an increase in soil nutrients, whilst this positive effect is not as evident in the presence of epigeic earthworms. The effect of earthworms on nutrient cycling has been further investigated with microbial functional genes, although existing reports largely focus on nitrogen cycling. Earthworms seem to enhance denitrification, most likely through the increase in organic compounds due to organic matter decomposition. By enhancing soil nutrient availability, earthworms indirectly promote plant growth, which has also been attributed to the induction of signal molecules. However, no experiment to date has been able to prove a direct causal relationship between specific signal molecules, earthworms and plant growth promotion. Finally, we propose a framework for earthworm-microbiota interactions and recommend further research.

These pores improve aeration, water absorption, drainage and easy root penetration. Soil aggregates formed by earthworms and associated microbes, in the casts and burrow walls play an indispensible role in soil air ecosystem. These aggregates are mineral granules bonded in a way to resist erosion and to avoid soil compaction both in wet and dry condition Fig. (13).

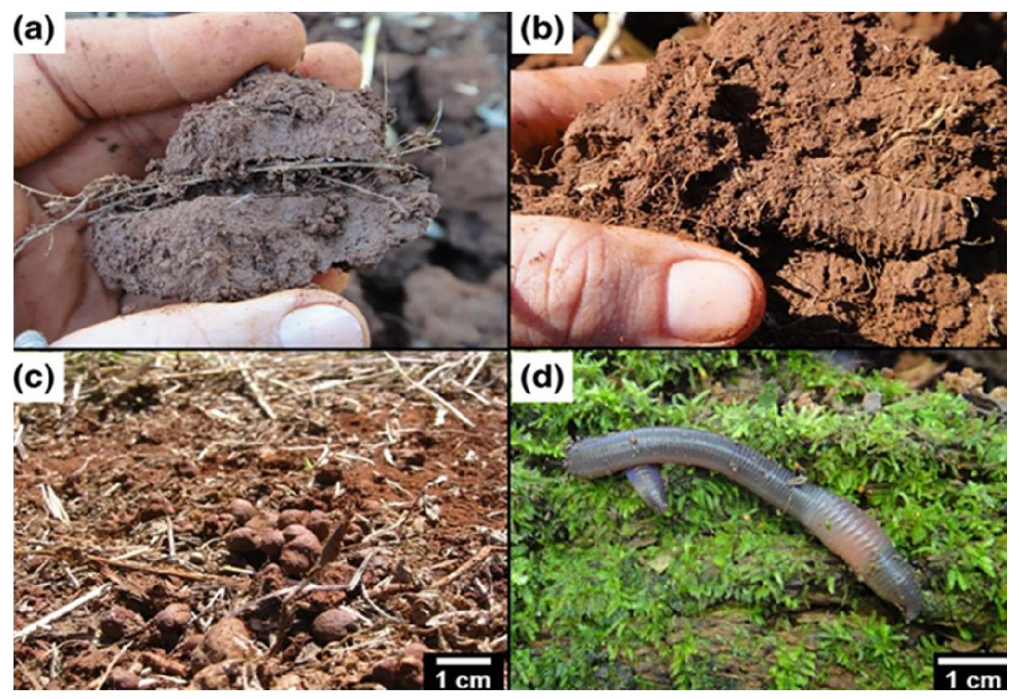

Fig. 13: Earthworm activity in no-tillage (NT) agricultural soils: (a) roots growing in an earthworm burrow in a clayey latosol under long-term NT in Guaraciaba, Santa Catarina; (b) castings of a large Glossoscolex sp., within the profile of the same site; (c) surface castings of Pontoscolex corethrurus in 2-year-old organic no-tillage on a clayey red latosol in S ao Jerônimo da Serra, Paraná; (d) Urobenus brasiliensis, an epi-endogeic earthworm found in various NT fields in Santa Catarina After Bartz et al., (2011), (2014).

Earthworms speed up soil reclamation and make them productive by restoring beneficial microflora Nakamura (1996). Thus, degraded unproductive soils and land degraded by mining could be engineered physically, chemically and biologically and made productive by earthworms. Hence, earthworms are termed as ecosystem engineers Brown et al., (2000), Munnoli et al., (2010) Fig. (14).

Gerrit Angst et al., (2019), reported that impact of earthworm particularly Epic-endogeic are important in no- tillage (NT) systems because they incorporate organic materials into the topsoil, accelerating carbon turnover and nutrient cycling, as well as increasing availability of various plant nutrients, such as calcium (Ca), nitrogen (N) and phosphorus (P) Bartz et al., (2010), which can positively affect plant growth Brown et al., (1999); van Groenigen et al., (2014). Earthworm castings 
are also known as hotspots of high microbial activity and even phytohormones production Puga-Freitas and Blouin, (2015); Medina- Sauza et al., (2019), The burrowing and casting activities of both endogeic and epic-endogeic species also enhance water storage, infiltration and oxygen diffusion in the soil Peixoto and Marochi, (1996), which may be particularly important in regions with high precipitation Brazil Alvares, et al., (2014). Additionally, plant roots to access deeper layers Fig. (15), mainly in clayey and compacted soils Ehlers, (1975), Springett and Gray, (1997) can use these burrows. The activity of epic-endogeic could help to improve organic matter incorporation into the topsoil, facilitating soil aggregation (biogenic structures) and carbon stabilization/sequestration Fig.(15) Bossuyt, et al., (2005); Lavelle et al., (1997).

Earthworm bioturbation, particularly cast production, has rarely been measured under NT Bescansa, et al., (2010); Botticelli, et al.,, (2019); Kaneda, et al., 2014), and although surface casting rates may achieve up to $3 \mathrm{Mg}$ of soil ha ${ }^{-1} \mathrm{yr}^{-1}$ in temperate NT fields in Japan Miura et al., (2008) and 68-112 $\mathrm{g} \mathrm{m}^{-2} \mathrm{~d}^{-1}\left(2.5-4.1 \mathrm{Mg} \mathrm{ha}^{-1} \mathrm{yr}^{-1}\right)$ in Nigerian NT fields Lal and Akinremi, (1983). Surface casts represent a variable proportion of earthworm casting, depending on the species present and soil conditions, particularly moisture, temperature, food supply and bulk density Barley, (1952); Joschko, et al., (1989); Scullion and Ramshaw, (1988); Whalen, et al., (2004). Total bioturbation rates may be much greater than those measured with surface casting, as most endogeic species deposit only a small fraction $(<10 \%)$ of the total casting on the soil surface James, (1991), whereas epiendogeics and anecics may deposit much more, ranging from 30 up to $90 \%$ of total ingestion Curry and Baker, (1998); Evans, (1948); Whalen et al., (2004). The long-term use of NT in many temperate regions with deep-burrowing anecic earthworms (e.g., L. terrestris) can also have important effects on organic matter incorporation, gas exchanges, water infiltration and nutrient movement in the soil profile Ehlers, (1975); Nieminen, et al., (2015); Shipitalo and Le Bayon, (2004); Shuster, et al., (2000); Subler and Kirsch, (1998).

\section{2- Role of earthworm in vermicomposting \\ 2-1- Their Biological effects}

Over the last few, decades' numerous human activities have led to an increased accumulation of waste materials. Therefore, waste management has become an important topic worldwide Demirbas (2011).The objective of SW management is to deal with waste in an environmentally and economically sustainable way Sabbas et al., (2003) Fig.(16).According to the literature, about 2.01 billion metric tons of solid waste are produced annually, and it is estimated that this number will increase to 3.40 billion metric tons by 2050, Hoornweg et al., (2012).SW includes organic and inorganic materials produced by different sources.

Lucia et al., (2019) reported that the circular economy aims to reduce the volume of waste generated in the world, transforming it into resources Fig. (16). The concept of indicator of circular economy was introduced to evaluate the improvement obtained regarding efficiency in terms of reduction, reuse and recycling of waste generated on the campus of the University of Lome (Togo). These indicators showed that $59.5 \%$ of the waste generated on the campus in 2018 could be introduced into the circular economy paradigm through composting, and $27.0 \%$ of the energy consumed could be replaced by clean energy obtained from biogas. The entire plastic fraction can be introduced into the circular economy paradigm by reusing plastic bottles and selling the rest in the port of the city. Thus, the income obtained could range from $€ 15.5 /$ day in 2018 to $€ 34.5 /$ day in 2027 . Concerning old tires, $1.5 \%$ of the rubber needed to pave the entire roadway of the campus could be replaced by the waste generated by the tires currently existing there. Consequently, waste management on the campus could be controlled thanks to these indicators, and this could serve as a model for the rest of the country. 


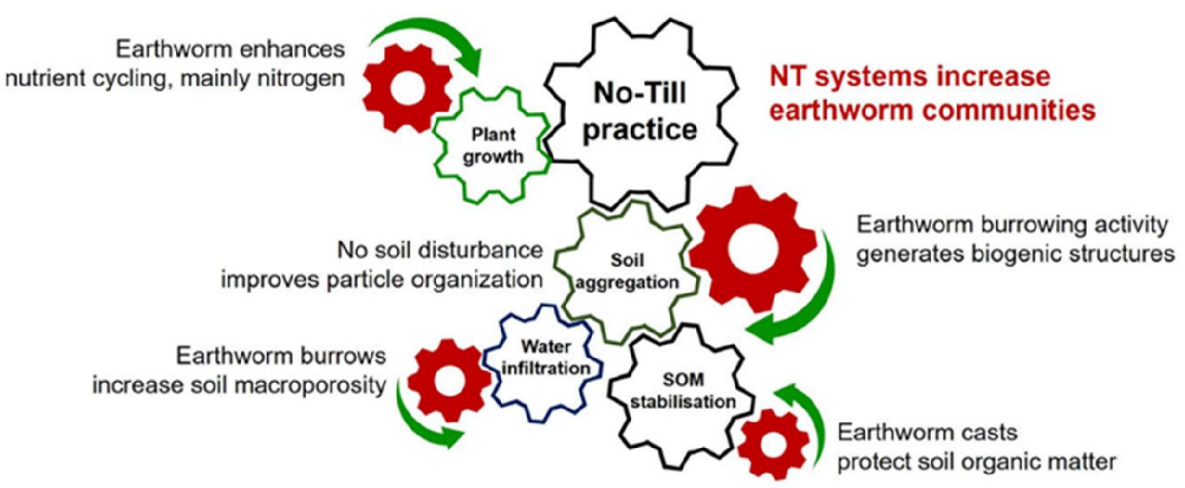

Fig. 14: Represents role of earthworms in some soil processes in no-tillage systems. After Lavelle et al., (2006), Wilian et al., (2020)

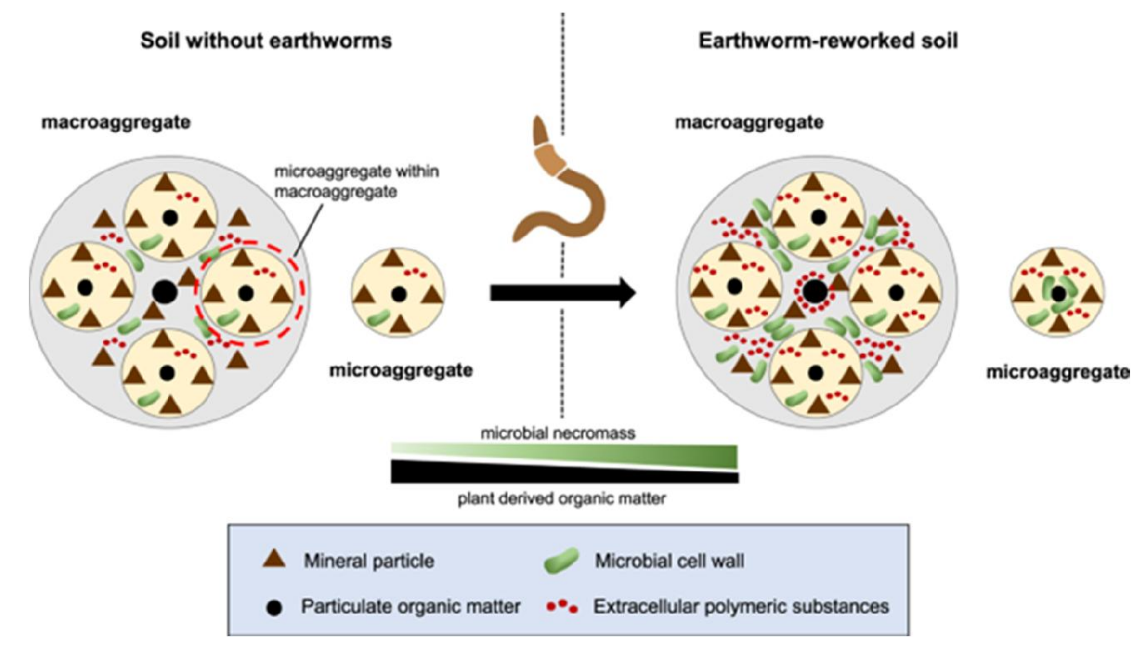

Fig. 15: Conceptual diagram depicting how earthworms as biochemical reactors affect the molecular composition of differently sized aggregates and soil fractions within. In soil devoid of earthworms, macro- and microaggregates are built up from occluded particulate organic matter surrounded by mineral soil particles. These particles are glued together by microbial material (cell walls and extracellular polymeric substances; EPS). When earthworms rework these soils through burrowing, casting and consumption of organic matter, they change the molecular composition of macro- and micro-aggregates through their stimulating effect on microorganisms: first, earthworm activity increases the microbial glue (i.e., microbial cell walls and EPS) with which mineral particles and microaggregates cohere in macro- aggregates and second, their activity creates nuclei enriched in microbial cell walls for the formation of new micro-aggregates. These processes are accompanied by an enhanced decomposition of plant-derived organic matter, particularly in the less stable soil fractions (non-protected plant fragments that freely reside in the soil and macro- aggregate occluded particulate organic matter). Ultimately, the presence of earthworms leads to larger amounts of microbial necromass in stable fractions from macro- and microaggregates by which the resilience to disturbances of that $\mathrm{C}$ is enhanced. After Gerrit- et al. (2019).

There are numerous classifications of SW that are also complex, but research on domestic waste Suthar and Singh (2008), municipal solid waste Kaviraj and Sharma (2003),sewage waste Dumontet et al., (1999), ashes Usmani et al., (2019), manures Arancon, et al., (2008), and many others in the literature can be found. Global waste, mostly industrial, can also be classified into hazardous and nonhazardous waste Bhat et al., (2018).Since the highest percentage is nonhazardous waste, there has been an increasing interest to find an eco-friendly, rapid and financially favorable technique for efficient waste management that is an entry point to sustainable development Samal et al., (2019), Ahmad et al., (2021). Vermicomposting is a non-thermophilic biological oxidation process in which organic material are converted into vermicompost which is a peat like material, exhibiting high porosity, aeration, 
drainage, water holding capacity and rich microbial activities Edwards (1998); Atiyeh et al., (2000b); Arancon et al., (2004a), through the interactions between earthworms and associated microbes. Vermiculture is a cost-effective tool for environmentally sound waste management Banu et al., (2001), Asha et al., (2008).

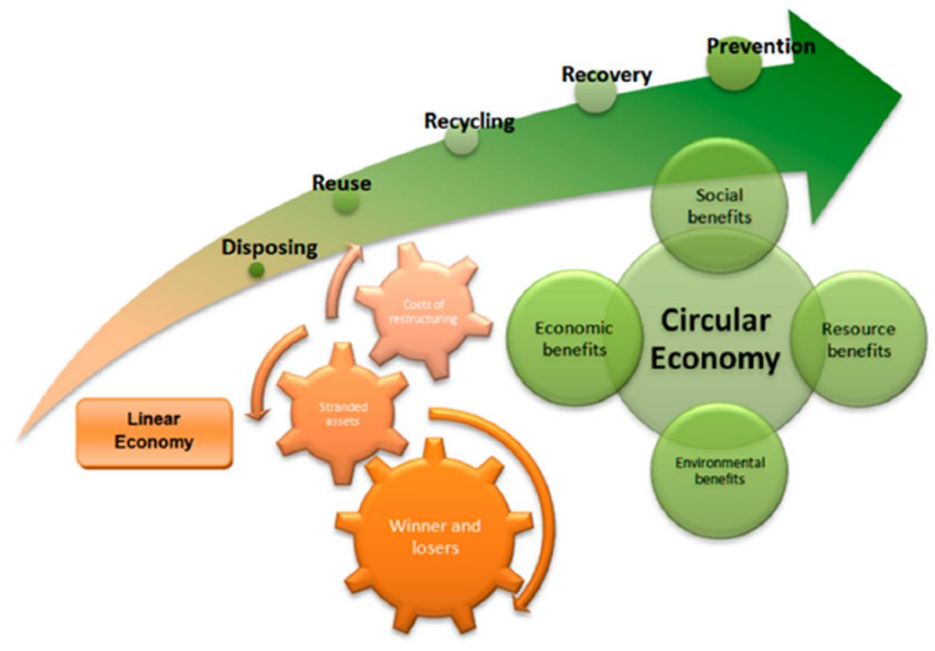

Fig. 16: Illustrates the transition from linear to circular economy model. After Lucia et al., (2019)

Earthworms are the crucial drivers of the process, as they aerate condition and fragment the substrate and thereby drastically alter the microbial activity and their biodegradation potential Fracchia et al., (2006), Lazcano et al., (2008). Vermicomposting is a biotechnological process of composting wide ranges of organic waste Elvira (1996), Suthar (2007), which includes specific earthworms' species that enhance the waste conversion into a very useful high-quality end product known as vermicompost Chattopadhyay (2012) Bhat et al., (2018). Vermicomposting involves bio-oxidative processes and the stabilization of organic material just as in composting; except in vermicomposting, this includes interactions between earthworms and microorganisms. The role of microorganisms is the production of enzymes that cause the biochemical decomposition of organic matter, while earthworms contribute to a larger microbial population through fragmentation and ingestion of fresh organic material. Besides the above, earthworms also interact with other organisms in the soil and can affect various microflora and micro fauna communities Lores, et al., (2006). Although vermicomposting and composting have some similarities, there are many significant differences between them, which are highlighted in numerous reviews Mahboub et al., (2019), Barthod, et al., (2018). These differences include the lack of the thermophilic phase in vermicomposting during which pathogens are reduced Dumontet et al., (1999), different requirements of moisture content that are higher for vermicomposting and differences of end-product quality where vermicomposting shows more positive effects on the physicochemical properties of the soil and on plant growth Tognetti et al., (2005), Guo et al., (2015). The conversion of industrial waste into vermicompost is important for pollution monitoring and controlling, since vermicompost has potential application in remediation and can be used for the reduction of the waste Shi, et al., (2019). Additionally, vermicompost has many beneficial effects on plants including induction of plant growth and yield. Therefore, it is also important for agriculture and horticulture purposes because it is used as fertilizing material Bhat et al., (2015), but also in terms of sustainable development.

Several enzymes, intestinal mucus and antibiotics in earthworm's intestinal tract play an important role in the breakdown of organic macromolecules Fig. (17).

Mucus located throughout the gut contains the same biological components, mucus properties vary with regional differences in function along the gastrointestinal tract Ermund et al., (2013), Fig. (17). The majority of nutrient uptake from digested food occurs in the small intestine and therefore there is a single, discontinuous and more penetrable mucus layer in this region Johansson et al., (2011). 

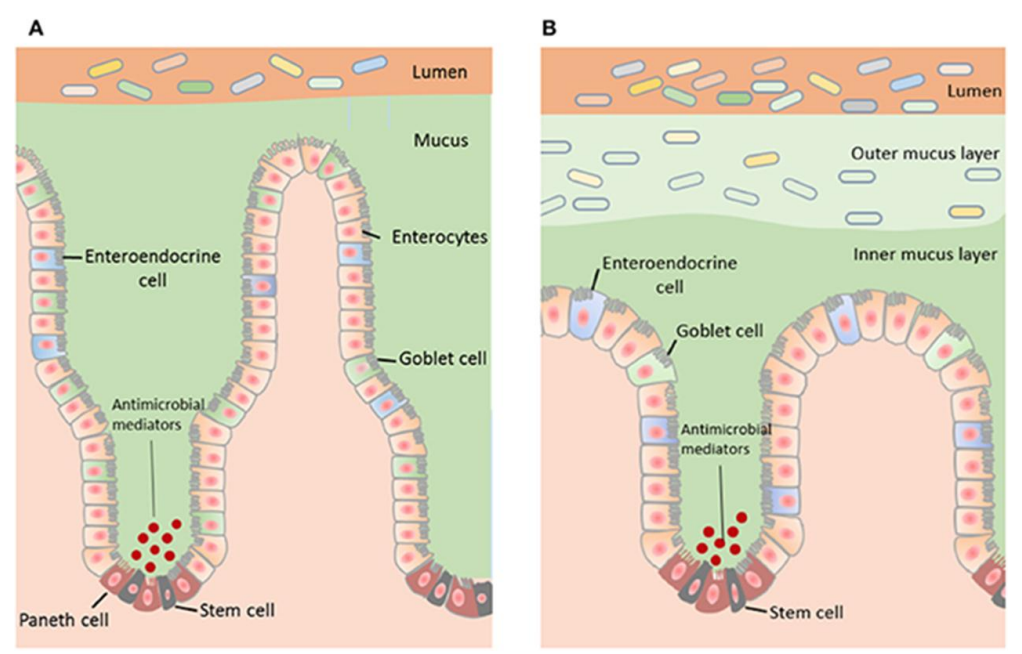

Fig. 17: Illustrates the structure of the mucus layer varies with regional locations within the GI tract. (A) The small intestine contains a single layer of mucus, which is loosely attached to the epithelium and easily penetrable. Bacteria within the small intestine are primarily repelled from the epithelium by antibacterial modulators. (B) The distal colon contains two mucus layers; a stratified adherent inner mucus layer and loosely adhesive outer mucus layer. The inner mucus layer of the colon is essentially sterile and the outer mucus layer harbors the intestinal microbiota. After Herath et al., (2017)

The discontinuity of the small intestinal mucus layer is important not only for the absorptive function of this region but also for the release of digestive enzymes localized in the brush border membrane of epithelial cells. These large mucus pores ensure efficient nutrient absorption by the host epithelium. A cocktail of antibacterial mediators such as defensins, lysozymes, and other peptides released by Paneth cells Peterson et al., (2007) also regulates the bacterial content of the mucosal barrier in the small intestine. Together, these mediators repel bacteria by generating an antibacterial gradient toward the lumen Johansson and Hansson, (2011); Vaishnava et al., (2011). Overall, antibacterial peptides kill bacteria via a range of mechanisms including by the formation of aggregates, recognition, and binding to bacterial cell wall peptidoglycans, and permeabilization of bacterial cell membranes Chairatana and Nolan, (2017). This serves to neutralize invasion by foreign particles and maintain epithelial crypts. This antimicrobial defense mechanism is critical in the small intestine due to the discontinuous and penetrable nature of the mucus in this region and is reflected by a higher density of Paneth cells and corresponding peptides (Ouellette, (2010).

Biodegradable organic wastes such as crop residues, municipal, hospital and industrial wastes pose major problems in disposal and treatment. Release of unprocessed animal manures into agricultural fields contaminates ground water causing public health risk. Vermicomposting is the best alternative to conventional composting and differs from it in several ways Gandhi et al., (1997). Vermicomposting hastens the decomposition process by 2-5 times, thereby quickens the conversion of wastes into valuable biofertilizer and produces much more homogenous materials compared to thermophilic composting (Bhatnagar and Palta (1996); Atiyeh et al., (2000a). Distinct differences exist between the microbial communities found in vermicompost and composts and hence the nature of the microbial processes is quite different in vermicomposting and composting Subler et al., (1998). The active phase of composting is the thermophilic stage characterized by thermophilic bacterial community where intensive decomposition takes place followed by a mesophilic maturation phase Lazcano et al., (2008); Vivas et al., (2009) Fig.(18). 


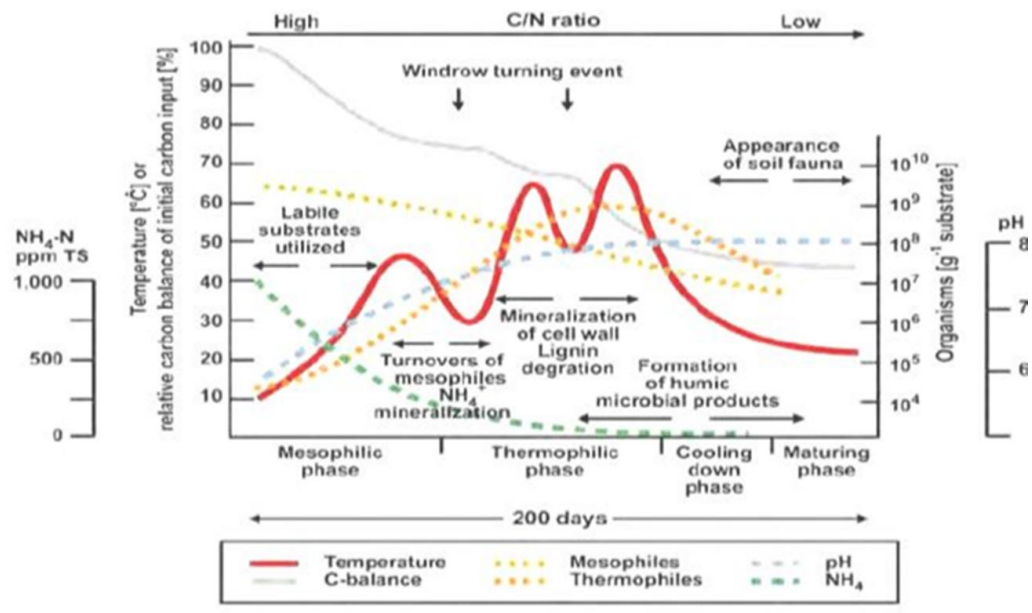

Fig. 18: Illustrates different stages during composting as function of time, appearance and succession of compost biota, temperature and further processes. After Masrat Maqbool and Rehman (2015).

Masrat Maqbool and Rehman (2015), they stated that composting often described as nature's way of recycling, is the biological process of breaking up of organic waste such as food waste, manure, leaves, grass trimmings, paper, worms, and coffee grounds, etc., into an extremely useful humus-like substance by various microorganisms including bacteria, fungi and actinomycetes in the presence of oxygen. According to Smith and Collins (2007) Composting is the biological decomposition and stabilization of organic matter derived from plants, animals or humans through the action of diverse microorganisms under aerobic conditions. The final product of this biological process is a humus-like stable substrate, being free of pathogens and plant seeds that can be beneficially applied to land as an agent for soil amelioration or as an organic fertilizer. Although historical traditions such as those of Ancient Egyptians or Pre-Columbian Indians of Amazonia suggest that composting is an ancient method for soil amelioration, fundamental scientific studies of this biological process were published only in the past four decades. Process engineering and the knowledge about the dependence and interaction of numerous competing forces and factors within a composting matrix have been just recently established Haug (1993). Multiple composting methods and systems have been developed, varying from small, homemade reactors used by individual households, over medium-sized, on-site reactors operated by farmers, to large, high-tech reactors used by professional compost producers. In spite of different process techniques, the fundamental biological, chemical and physical aspects of composting remain always the same. This concerns for example the suitability of different input materials and amendments as well as their appropriate composition, substrate degradability, moisture control, porosity, free air space, energy balance as well as decomposition and stabilization Haug (1993), Bidlingmaier et al., (2000). All proper composting processes go through four stages: (1) mesophilic, (2) thermophilic, (3) cooling, finally ending with (4) compost maturation Fig. (18). The duration of each stage depends on the initial composition of the mixture, its water content, aeration and quantity and composition of microbial populations Neklyudov et al., (2006), Smith and Collins (2007)

Vermicomposting is a mesophilic process characterized by mesophilic bacteria and fungi Benitez et al., (1999). Vermicomposting comprises of an active stage during which earthworms and associated microbes jointly process the substrate and the maturation phase that involves the action of associated microbes and occurs once the worm's moves to the fresher layers of undigested waste or when the product is removed from the vermireacter. The duration of the active phase depends on the species and density of the earthworms involved Ndegwa et al., (2000); Lazcano et al., (2008), Aira et al., (2011). A wide range of organic wastes viz., horticultural residues from processed potatoes Edwards (1988); mushroom wastes Edwards (1988); Tajbakhsh et al.(2008); horse wastes Hartenstein et al., (1979); Edwards et al., (1998); pig wastes Chan and Griffiths (1988); Reeh (1992); brewery wastes Butt (1993); sericulture wastes Gunathilagraj and Ravignanam 1996); municipal sewage sludge Mitchell et al., (1980); Dominguez et al., (2000); agricultural residues Bansal and Kapoor (2000); weeds Gajalakshmi et al., (2001); cattle dung Gunadi et al., (2002); industrial refuse such as paper wastes Butt (1993); 
Elvira et al., (1995); Gajalakshmi et al., (2002); sludge from paper mills and dairy plants Elvira et al., (1997); Banu et al., (2001); domestic kitchen wastes Sinha et al., (2002); urban residues and animal wastes Edwards et al., (1985); Edwards (1988) can be vermicomposted Sharma et al.(2005).

\section{3-2 Effects of vermicomposting on chemical properties of wastes.}

Earthworm activity reduced $\mathrm{pH}$ and C: N ratio in manure Gandhi et al., (1997); Atiyeh et al., (2000b). Chemical analysis showed vermicompost had a lower pH, EC, organic carbon (OC) Nardi et al., (1983); Albanell et al., (1988); Mitchell (1997), C:N ratio Riffaldi and Levi-Minzi (1983); Albanell et al., (1988), nitrogen and potassium and higher amounts of total phosphorous and micronutrients compared to the parent material, Hashemimajd et al., (2004). Slightly decreased $\mathrm{pH}$ values of vermicompost compared to traditional compost might be attributed due to mineralization of $\mathrm{N}$ and $\mathrm{P}$, microbial decomposition of organic materials into intermediate organic acids, fulvic acids, humic acids Lazcano et al., (2008), Albanell et al., (1988); Chan and Griffiths (1988), Subler et al., (1998) and concomitant production of $\mathrm{CO}_{2}$ Elvira et al., (1998); Garg et al., (2006) Fig. (19).

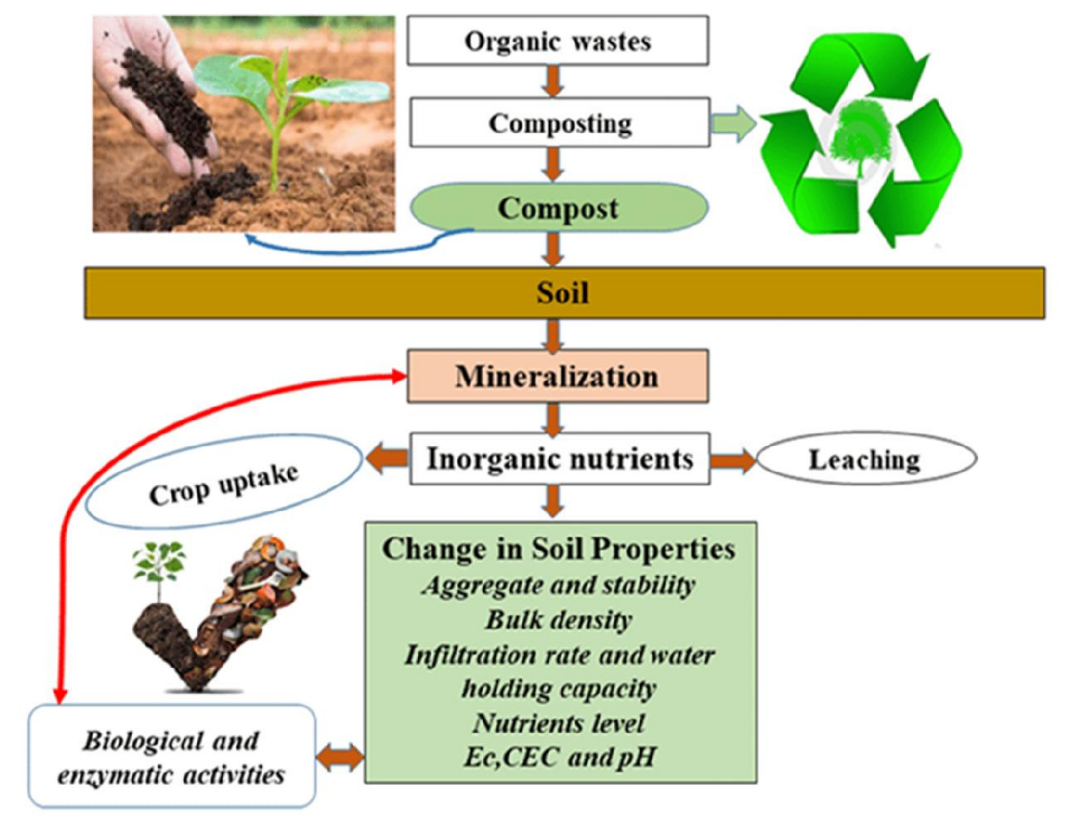

Fig. 19: Illustrates Schematic diagram of compost mineralization after application to soil EC: Electrical conductivity, CEC: Cation exchange capacity.

Vermicomposting of paper mill and dairy sludge resulted in 1.2-1.7 fold loss of organic carbon as $\mathrm{CO}_{2}$ Elvira et al., (1998). In contrast to the parent material used, vermicompost contain higher humic acid substances Albanell et al., (1988). Humic acid substances occur naturally in mature animal manure, sewage sludge or paper-mill sludge, but vermicomposting drastically increases the rate of production and their amount from 40-60 percent compared to traditional composting. The enhancement in humification processes is by fragmentation and size reduction of organic matter, increased microbial activity within earthworm intestine and soil aeration by earthworm feeding and movement Dominguez and Edwards, (2004). Electrical conductivity indicates the salinity of the organic amendment. Minor production of soluble metabolites such as ammonium and precipitation of dissolved salts during vermicomposting lead to lower EC values. Compared to the parent material used, vermicompost contain less soluble salts and greater cation exchange capacity Holtzclaw and Sposito (1979), Albanell et al., (1988). C: $\mathrm{N}$ ratio is an indicator of the degree of decomposition. During the process of bio oxidation, $\mathrm{CO}_{2}$ and $\mathrm{N}$ is lost and loss of $\mathrm{N}$ takes place at a comparatively lower rate. Comparison of compost and vermicompost showed that vermicompost had significantly less $\mathrm{C}$ : $\mathrm{N}$ ratios as they underwent intense decomposition Lazcano et al., (2008). Vermicomposting of cow manure using earthworm species E. andrei Atiyeh et al., (2000b) and E. foetida Hand et al., (1988) favored nitrification, resulting in the 
rapid conversion of ammonium-nitrogen to nitrate-nitrogen. Vermicomposting increased the concentration of nitrate-nitrogen to 28 fold after 17 weeks, while in conventional compost there was only 3-fold increase Subler et al., (1998); Atiyeh et al., (2000a). Increase in ash concentration during vermicomposting suggests that vermicomposting accelerates the rate of mineralization Albanell et al., (1988). Mineralization is the process in which the chemical compounds in the organic matter decompose or oxidise into forms that could be easily assimilated by the plants. Increase in ash content increases the rate of mineralization. Ash is an alkaline substance that hinders the formation of $\mathrm{H}_{2} \mathrm{~S}$ as well as improves the availability of $\mathrm{O}_{2}$ and thereby renders composts odorless. Thus, vermicomposting increases the ash content and accelerates the rate of mineralization that is essential to make nutrients available to plants. Zhang et al., (2000); Garg et al., (2006), they reported that increasing of total phosphorous (TP) in vermicompost is probably due to mineralization and mobilization of phosphorus resulting from the enhanced phosphatase activity by microorganisms in the gut epithelium of the earthworms Vermicompost showed a significant increase in exchangeable $\mathrm{Ca}^{2+}, \mathrm{Mg}^{2+}$ and $\mathrm{K}^{+}$compared to fresh sludge indicating the conversion of nutrients to plant-available forms during passage through the earthworm gut Garg et al.(2006); Yasir et al., (2009a). Vermicompost contain higher nutrient concentrations, but less likely to produce salinity, than composts. Additionally, vermicompost possess outstanding biological properties and have microbial populations significantly larger and more diverse compared to conventional composts Edwards (1998) Fig. (20).
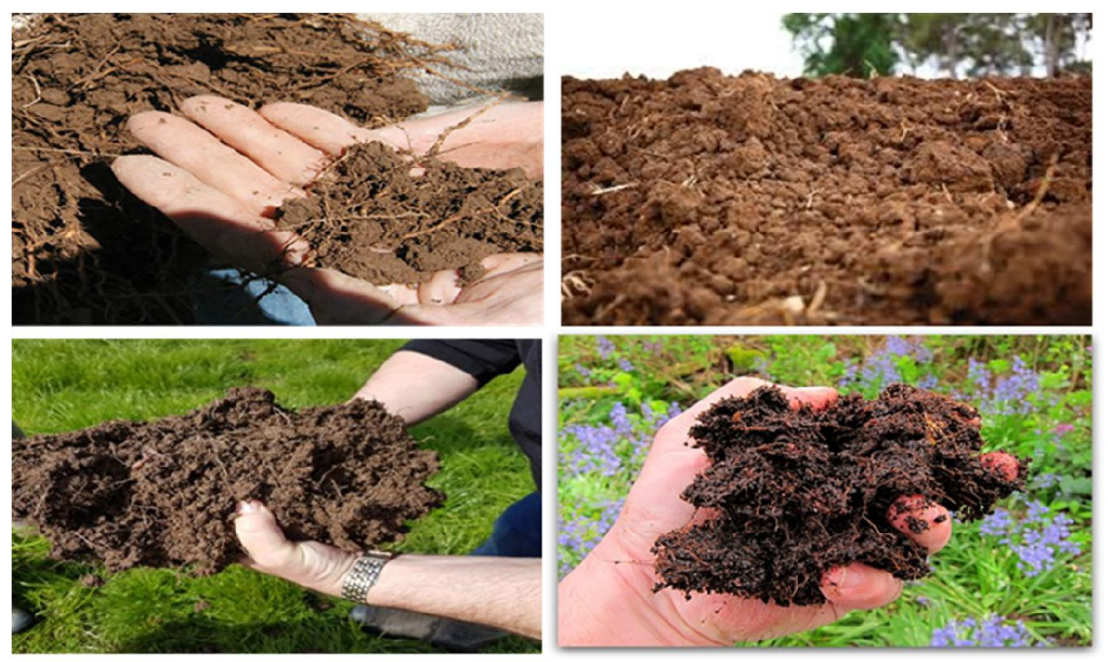

Fig. 20: Vermicompost enhanced soil health that improve physical, chemical, and biological Condition, having the Capability to sustain the growth and development of land plants.

Soil supplemented with vermicompost showed better plant growth compared to soil treated with inorganic fertilizers or cattle manure Kalembasa (1996); Subler et al., (1998) Fig. (21). Intensive crop production including vegetables by using inorganic fertilizers has led to increased yield at the expense of product quality and environmental degradation. Rational use of $\mathrm{N}$ fertilizers in vegetable production systems to maintain sustainable yield and to minimize the health risk associated with excessive accumulation of nitrate is of critical importance. The use of organic farming with organic amendments to soil as nutrient inputs is increasing and it is an alternative agricultural practice for sustaining economically viable crop production with minimal environmental pollution Padel, et al., (2009). 

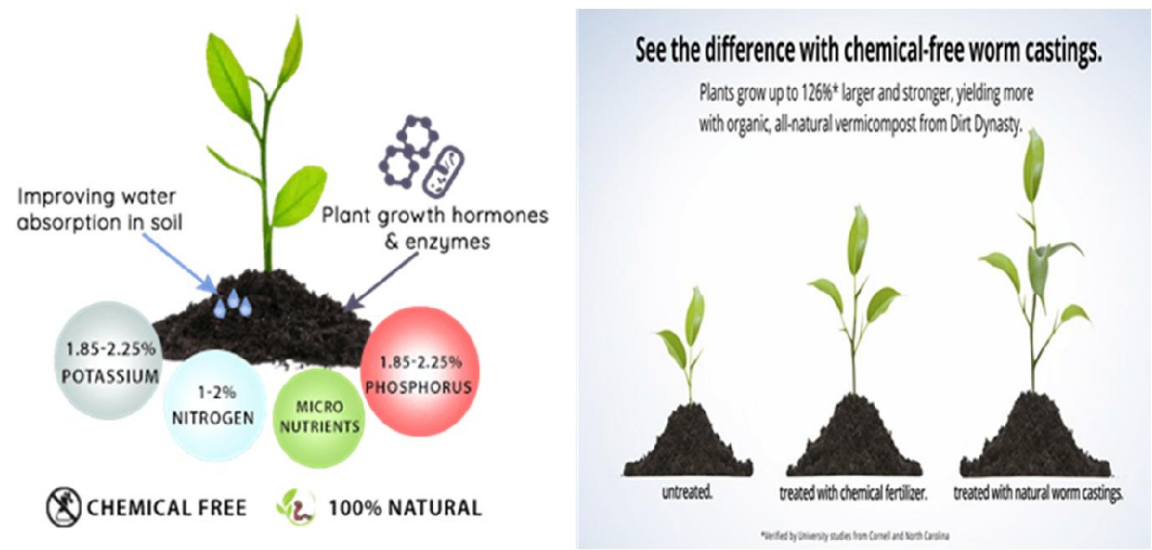

Fig. 21: Represents the major benefits of vermicompost

Vermicomposts are products of a non thermophilic biodegradation of organic materials through interactions between earthworms and microorganisms Atiyeh, et al., (2002) They are materials characterized by high porosity, aeration, drainage, water holding capacity and microbial activity Atiyeh, et al., (1999). The application of vermicompost to soil is considered as a good management practice in any agricultural production system because of the stimulation of soil microbial growth and activity, subsequent mineralization of plant nutrients, and increased soil fertility and quality Arancon et al., (2006), Ferreras et al., (2006). Plants fertilized with vermicompost have shown greater ability to assimilate essential macro and micronutrients, and resulted in improved root development Atiyeh et al., (2002) Arancon et al., (2006), Zaller (2007), Ali, et al., (2007). The presence of plant growth influencing substances, such as plant growth hormones and humic acids has also been suggested as a possible factor contributing to increased plant growth and yields, Muscolo, et al., (1999) Arancon, et al., (2004a), Lettuce, a vegetable of great consumption in Greece can be produced under different temperature ranges, which allows it to be marketed throughout the year. Accumulation of nitrate in lettuce has been affected by the soil texture and the source of $\mathrm{N}$ fertilizer McCall and Willumsen (1998), the timing of fertilizer-N release Tesi and Lenzi (1998), the light intensity and duration Behr and Wiebe (1992), crop season Gianquinto et al., (1992), and lettuce type and cultivar Siomos, (2000), Escobar-Gutierrez et al., (2002).

Fokion et al., (2012) reported that effects of earthworm-processed cattle-manure (vermicompost) on the growth, productivity and quality characteristics of five lettuce (Lactuca sativa L.) cultivars were investigated in greenhouse experiments during two successive crop seasons (winter and spring season). Four treatments were applied, vermicompost combined with soil in proportions of 10 and $20 \%(\mathrm{w} / \mathrm{w})$, inorganic fertilization and control soil. Vermicompost treatments, in both concentrations, affected leaf biomass in all cultivars with leaf fresh weight to be significantly greater as compared with the untreated soil, than fertilization treatments during the winter crop season, application of vermicompost was greater and close to the inorganic fertilization treatments particularly during the spring cultivation. Leaf number and leaf dry weight were significantly affected with vermicompost addition as compared with the control and inorganic fertilization treatments during the winter cultivation whereas root biomass was significantly increased in the vermicompost treatments with the differences to be greater during the spring crop season. Photosynthetic rate did not differ significantly with the addition of vermicompost as compared with the inorganic fertilization but was greater than in the control mainly in the spring experiment. Total chlorophyll concentration was also increased in the two-vermicompost treatments compared with the control in both cultivations. The addition of $20 \%$ vermicompost in the soil resulted in significantly higher chlorophyll levels than the inorganic fertilization but only during the winter crop season. Ascorbic acid concentration was affected by genotype but no significant differences with the addition of vermicompost. Highest nitrate concentration for all lettuce cultivars particularly during the winter crop with significantly greater levels $\left(460-583 \mathrm{mg} \mathrm{kg}^{-1} \mathrm{FW}\right)$ in the inorganic fertilization treatment in both crop seasons.

In field studies of pineapple (Ananas comosus var. MD2), Mawiyah et al., (2018) reported that Vermicompost is essential plant nutrients, and has the ability to enhance the condition and increase the 
quality of the soil, soil $\mathrm{pH}$ was increased after a second supplementation of vermicompost and contained significantly higher total $\mathrm{N}(0.15 \%)$ in the soils as compared to the control $(0.07 \%)$. No significant difference between pineapple (Ananas comosus var. MD2), supplied with chemical fertilizer and vermicompost in terms of plant height, number of leaves, or the length and width of D-leaves. However, different fertilization treatments were found to affect the yield and physical characteristics of pineapple (Ananas comosus var. MD2) fruits. Plants supplied with chemical fertilizer produced the highest fruit yield $\left(136.97 \mathrm{tha}^{-1}\right)$ with the largest fruit size, followed by vermicompost $\left(121.39 \mathrm{tha}^{-1}\right)$ and the control $\left(94.93 \mathrm{t} \mathrm{ha}^{-1}\right)$. However, fruits supplied with vermicompost were observed to have the smallest crowns. Taken together, these results indicated that the use of vermicompost produced pineapple plants with excellent growth performance, comparable to that obtained when chemical fertilizer was used. In addition, based on the cost analysis conducted, it was shown that the total cost (fertilizer and labor) for plants grown with vermicompost was lower than plants grown with chemical fertilizer. However, the usage of vermicompost as the single source of nutrients is not suggested for this type of soil and field conditions, but can be used as a supplement to maintain the soil quality and ensure agricultural sustainability.

Vermicompost can significantly influence the growth and productivity of plants Kale et al., (1992); Kalembasa (1996); Edwards (1988); Sinha et al., (2009) due to their micro and macro elements, vitamins, enzymes and hormones Makulec (2002). Vermicomposts contain nutrients such as nitrates, exchangeable phosphorus, soluble potassium, calcium, and magnesium in plant available forms Orozco et al., (1996); Edwards (1998) and have large particular surface area that provides many microsites for microbial activity and for the strong retention of nutrients Shi-wei and Fu-zhen (1991). Uptake of nitrogen $(\mathrm{N})$, phosphorus $(\mathrm{P})$, potassium $(\mathrm{K})$ and magnesium $(\mathrm{Mg})$ by rice (Oryza sativa) plant was highest when fertilizer was applied in combination with vermicompost Jadhav et al., (1997). N uptake by ridge gourd (Luffa acutangula) was higher when the fertilizer mix contained 50\% vermicompost Sreenivas et al., (2000). Apart from providing mineralogical nutrients, vermicomposts also contribute to the biological fertility by adding beneficial microbes to soil. Mucus, excreted through the earthworm's digestive canal, stimulates antagonism and competition between diverse microbial populations resulting in the production of some antibiotics and hormone-like biochemical, boosting plant growth Edwards and Bohlen (1996). In addition, mucus accelerates and enhances decomposition of organic matter composing stabilized humic substances that embody water-soluble Phytohormonal elements Edwards and Arancon (2004) and plant-available nutrients at high levels Atiyeh et al., (2000c). Adding vermicasts to soil improves soil structure, fertility, plant growth and suppresses diseases caused by soil-borne plant pathogens, increasing crop yield Chaoui et al., (2002); Scheuerell et al., (2005); Singh et al., (2008). Kale (1995) reported the nutrient status of vermicomposts with organic carbon $9.15-17.98 \%$, total nitrogen $0.5-1.5 \%$, available phosphorus $0.1-0.3 \%$, available potassium $0.15 \%$, calcium and magnesium $22.70-70 \mathrm{mg} / 100 \mathrm{~g}$, copper 2-9.3 ppm, zinc $5.7-11.5 \mathrm{ppm}$ and available sulphur 128-548 ppm. Effects of a variety of vermicomposts on a wide array of field crops Chan and Griffiths (1988); Arancon et al., (2004b), vegetable plants Edwards and Burrows (1988); Wilson and Carlile (1989); Subler et al., (1998); Atiyeh et al.(2000b), ornamental and flowering plants Edwards and Burrows (1988); Atiyeh et al., (2000c) under greenhouse and field conditions have been documented. Vermicomposts are used as alternative potting media due to their low-cost, excellent nutrient status and physiochemical characters. Considerable improvements in plant growth recorded after amending soils with vermicomposts have been attributed to the physico-chemical and biological properties of vermicomposts. Vermicompost addition favorably affects soil $\mathrm{pH}$, microbial population and soil enzyme activities Maheswarappa et al., (1999) and reduces the proportion of water-soluble chemical, which cause possible environmental contamination Mitchell and Edwards (1997). Vermicompost addition increases the macrospore space ranging from $50-500 \mu \mathrm{m}$, resulting in improved air-water relationship in the soil, favourably affecting plant growth Marinari et al., (2000). Evaluation of various organic and inorganic amendments on growth of raspberry proves that vermicompost has beneficial buffering capability and ameliorate the damage caused by excess of nutrients that may otherwise cause phytotoxicity Subler et al., (1998). Thus, vermicompost acts a soil conditioner Albanell et al., (1988) and a slow-release fertilizer Atiyeh et al., (2000a). During vermicomposting the heavy metals forms complex, aggregates with humic acids and other polymerized organic fractions resulting in lower availability of heavy metals to the plant, which are otherwise phytotoxic Dominguez and Edwards (2004). Soil amended with vermicompost produced better quality fruits and vegetables with 
less content of heavy metals or nitrate, than soil fertilized with mineral fertilizers Kolodziej and Kostecka (1994) Fig. (22).

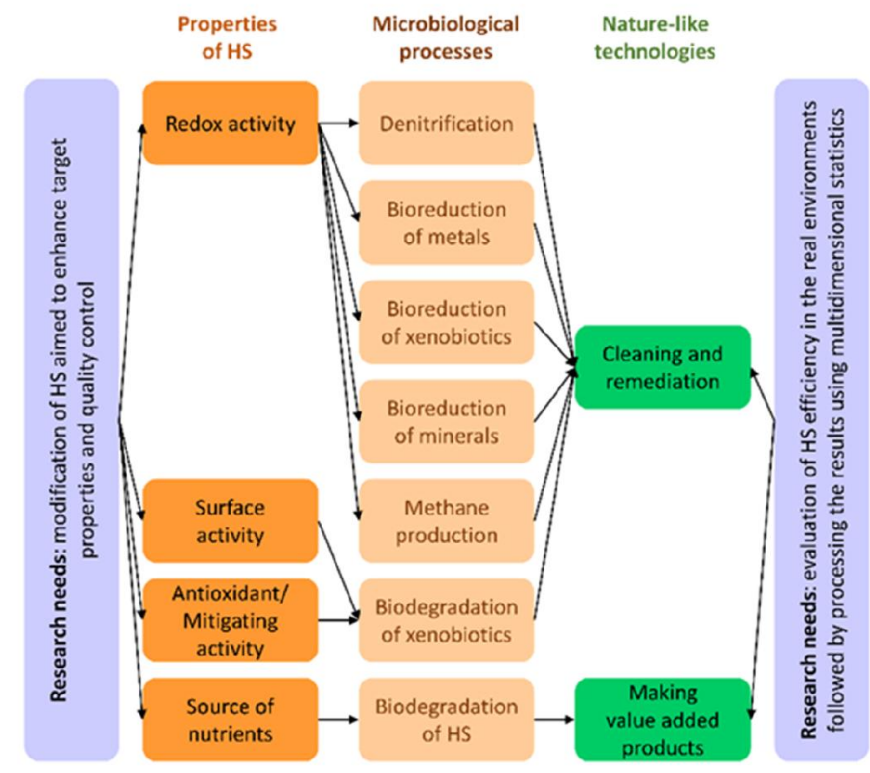

Fig. 22: Principal research needs for microorganism-HS interactions that can support the development of Nature-like technologies. After Kulikova N.A. and Perminova I.V. (2021)

Kulikova N.A. and Perminova I.V. (2021). Reported that data on interactions between microorganisms and HSs and properties of HSs are discussed in terms of microbial utilization, degradation, and transformation. Bacteria of the phylum Proteobacteria and fungi of the phyla Basidiomycetes and Ascomycota were found to be the main HS degraders, while Proteobacteria, Actinobacteria, Bacteroidetes, and Firmicutes were found to be the predominant phyla in humicreducing microorganisms (HRMs). Some promising aspects of interactions between microorganisms and HSs are discussed as a feasible basis for nature-like biotechnologies, including the production of enzymes capable of catalyzing the oxidative binding of organic pollutants to HSs, while electron shuttling through the utilization of HSs by HRMs as electron shuttles may be used for the enhancement of organic pollutant biodegradation or lowering bioavailability of some metals. Utilization of HSs by HRMs as terminal electron acceptors may suppress electron transfer to $\mathrm{CO}_{2}$, reducing the formation of $\mathrm{CH}_{4}$ in temporarily anoxic systems. To facilitate the development of HS-based technologies, complex studies addressing these factors are in demand.

\section{3-3 Effect of Vermicompost on Plant Growth and Yield}

Fertilizers have been used since ancient times to increase the height and quality of the crop yield. In recent decades, the improper use of mineral fertilizers has resulted in pollution of soil, water and air and, therefore, raised important questions regarding food quality and environmental safety Savci, (2012). Accordingly, one of the best solution is to use organic fertilizers, especially vermicompost. Discouraging the use of inorganic fertilizers and their replacement by vermicompost makes vermicompost a significant factor in sustainable agriculture and its future. The characteristics that make vermicompost an effective fertilizer is homogeneity, high porosity, high water-holding capacity, stability, low C:N ratio and the fact that it is an ecofriendly, nutrient-rich material Lon cari et al., (2005), Joshi et al., (2015). Vermicompost is known to have a wide range of effects on plants, and most of them are beneficial. In general, it can be said that vermicompost improves growth, yield and quality of plants. All beneficial effects of vermicompost include stimulation of root and shoot development, increasing seed germination, leaf area, root branching, fruit yield, nutritional quality, stimulation of plant flowering, affecting the biomass, photosynthetic pigments, photosynthesis and respiration rates Usmani, et al., (2019). Except for positive effects of vermicompost on plants, it is important to mention 
vermicompost water extracts also called vermicompost 'teas', which have become increasingly current in recent years and show similar effects as vermicompost Mahboub et al., (2019), Arancon et al., (2020), Ayastuy et al., (2020). When generally speaking about improved plant growth and development, in substrate enriched with vermicompost, it is primarily due to the presence of humic acids (HAs) Arancon et al., (2003),Hernandez, et al., (2015) and different micro and macronutrients Ramnarain et al., (2017), which are converted during vermicomposting into more plant-available forms. Macronutrients such as nitrogen and phosphorus are more available to plants due to $\mathrm{N}_{2}$ fixers and phosphate solubilizing bacteria Chitrapriya, et al., (2013). Considering that phosphorus is often one of the prime limiting factors for plant growth and the least mobile and therefore mostly unavailable to plants compared to other nutrients, phosphate-solubilizing bacteria play an important role in supplying phosphate to plants. Khan et al., (2007) reported the utilization of these bacteria for direct application in agriculture as a promising strategy with great potential for use in sustainable agriculture. Suthar and Singh (2009) found that the content of nutrients such as $\mathrm{N}, \mathrm{P}, \mathrm{K}, \mathrm{Ca}, \mathrm{Cu}, \mathrm{Mg}, \mathrm{Fe}$ and $\mathrm{Zn}$ is much higher in vermicompost than in farmyard manure, and it resulted in increased growth and yield of garlic (Allium sativum) Fig. (23).

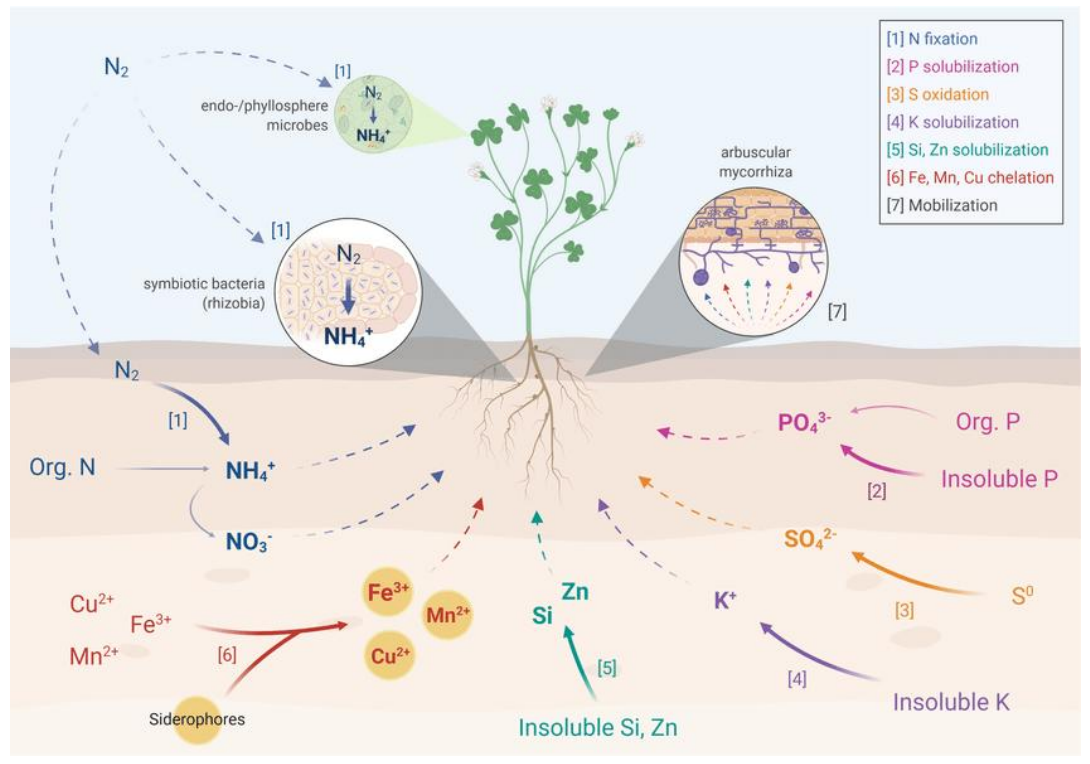

Fig. 23: Illustrates the key microbially mediated nutrient transformation/acquisition pathways associated with biofertilizers. Full arrows represent microbial transformations whereas dashed arrows represent mobilization/movement of nutrients. Created with Bio Render. After Mitter et al., (2021)

Manivannan, et al., (2009) showed that the application of vermicompost from sugar mill wastes caused a decrease in $\mathrm{pH}$ value both in clay loam and sandy loam soils due to the acidifying effects of organic acids. Decreased $\mathrm{pH}$ to values between 6 and 7 can promote the availability of nutrients to the plants and uptake by plants, which results in the better growth of beans (Phaseolus vulgaris). Some of the parameters that indicate plant growth and development are closely related to change in photosynthetic parameters. The effect of vermicompost on photosynthetic pigments, photosynthesis and respiration rates is well documented. Usmani et al., (2019).reported an increase in chlorophyll a, chlorophyll $b$ and carotenoids with an increase in the concentration of vermicompost $(3,6,9,12$, and $15 \%$ ) in two plant species, Lycopersicon esculentum and Solanum melongena. According to that, increased plant pigments resulted in a high photosynthetic activity, which can also enhance growth and yield, which is evident through the increase in the weight and length of shoots, the number of leaves, flowers and fruits. In regards to the nutrients, it is known that nutrient uptake can be affected by Has through the synthesis and functionality of membrane proteins, especially proton pumps that increase the electrochemical proton gradient across the plasma membrane (PM) Morsomme, and Boutry (2000).Vermicompost enriched with HAs plays an important role in stimulating plant growth and 
development. Namely, Gholami et al., (2019), determined the effects of HA at 0, 0.3, 0.6 and $0.9 \mathrm{~kg} \mathrm{ha}$ ${ }^{1}$ and vermicompost at $0,5,7.5$ and $10 \mathrm{t} \mathrm{ha}^{-1}$ on mineral elements $\mathrm{N}, \mathrm{P}, \mathrm{K}, \mathrm{Fe}, \mathrm{Zn}, \mathrm{Mn}$ and $\mathrm{Cu}$ uptake and photosynthetic pigment concentrations of chicory Fig. (24).

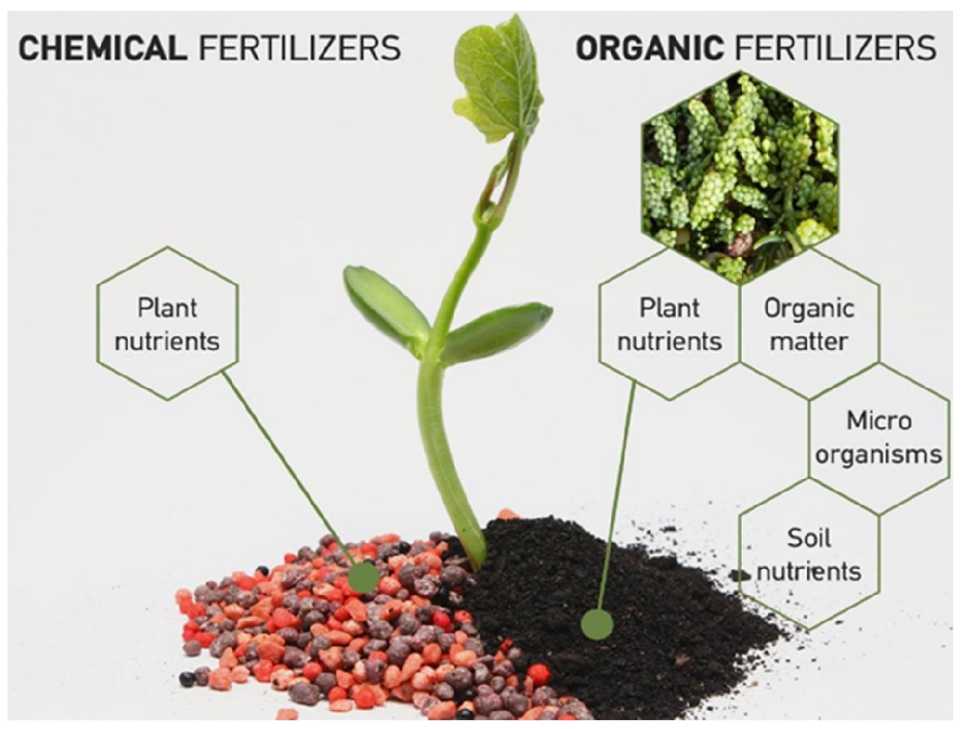

Fig. 24: Illustrates both organic and inorganic fertilisers provide plants with the nutrients needed to grow healthy and strong. Each contains different ingredients and supplies these nutrients in different ways. Organic fertilizers work over time to create a healthy growing environment, while inorganic fertilizers provide rapid nutrition.

Due to the presence of HAs, the activity of microorganisms in the soil was improved that finally increased N, P and K content in plants Fig. (25). This is an example of 'indirect action' of HAs on plants, while there is another 'direct action' that includes plant hormones Arancon et al., (2003). As plant growth hormones are found in an aqueous solution of vermicompost, Arancon et al., (2003), hypothesized that hormones such as auxins (indole-3-acetic acid-IAA), which are water soluble, may adsorb on to humates and become more persistent in soil and thus extend the period of action on the plants. When it comes to plant hormones, some bacterial species can synthesize them too. GómezBrandón et al., (2019), observed an increase in specific genes related to salicylic acid synthesis in grape marc vermicompost, while Domínguez et al., (2019), and found a general increase in metabolism genes also connected to salicylic acid synthesis in Scotch broom vermicompost. Salicylic acid affects multiple aspects of plant growth and development, but it is also an essential regulator of plant-microbe interactions Maruri-López et al., (2019).

Phytohormones are one of the factors that can affect the ability of plants to differentiate cells and tissues into plant organs such as roots and shoots. In support of this, Arancon et al., (2003) evaluated different concentrations $(1,2,5$ and $10 \%)$ of water extracts from vermicompost on rooting characteristics of stem cuttings. As they found a combination of auxins, cytokinins, GA and HAs in water extracts, they connected it with increased rooting in stem cuttings. Furthermore, Olaetxea et al., (2018), showed that both the root plasma membrane H+-ATPase activity and root abscisic acid (ABA) play a crucial role in the root growth-promoting action of SHA (humic acids with a sedimentary origin and extracted from leonardite) in cucumber. Increased $\mathrm{H}+-\mathrm{ATP}$ ase activity, except increasing ABA concentration in roots, mediates an increase in cytokinin concentration and action in shoots. ABA is not the only signal involved in SHA-mediated root growth. This signal pathway is just a part of a much more complex signal network that also includes auxin, NO and ethylene Mora, et al., (2014), Olaetxea et al., (2018). Olaetxea et al., (2018), assumed that in all possible signaling pathways connected with root growth that is caused by the presence of Has and reactive oxygen species (ROS) might have an important role. Furthermore, bioactivity levels of HAs are not only a result of phytohormones-related effects but also a presence of other plant growth regulatory substances, such as alkamides present in 
HA. Zandonadi et al., (2018) described the effects of N-isopropyldecanamide, the unbound fraction of HA isolated from cattle manure vermicompost, on the $\mathrm{PM} \mathrm{H}+$-ATPase activity in maize seedling roots. $\mathrm{PM} \mathrm{H}+-\mathrm{ATPase}$ activity increased due to higher concentrations of $\mathrm{N}$-isopropyldecanamide which resulted in enhanced root development which was evident from an increase in root dry mass, total length and superficial area.

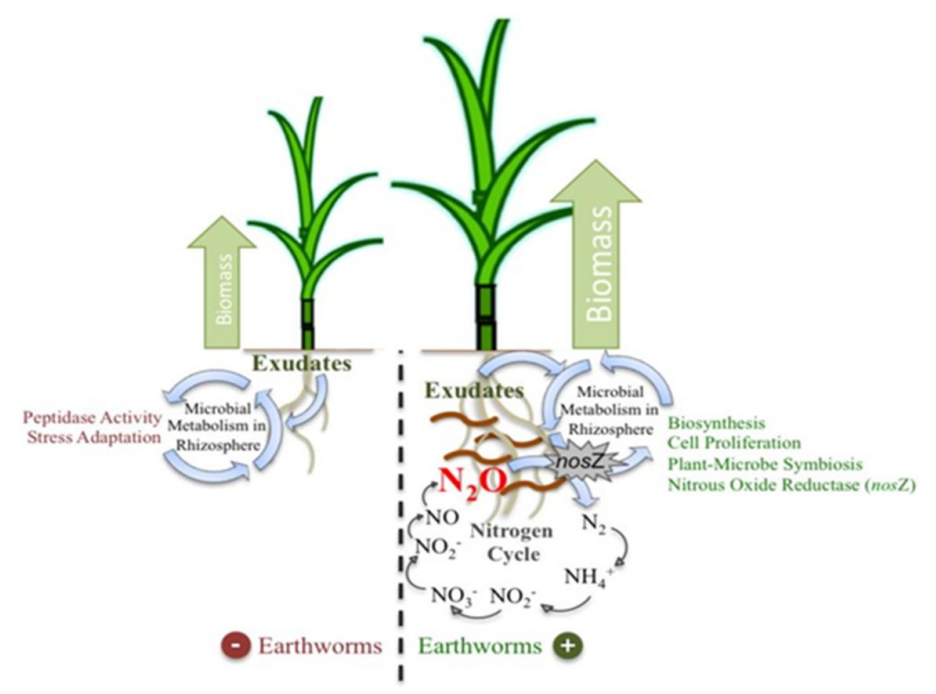

Fig. 25: Hypothetical model representing the mechanism by which earthworms may influence rhizosphere microbes in sugarcane. The collective findings in the present study demonstrate that earthworm activity alters microbial functions in the soil (bulk soil and rhizosphere). We propose that the cause for that is the increase in the availability of nutrients and the elevated abundance of $\mathrm{N}_{2} \mathrm{O}$, both known to be originated during the process of soil digestion inside worm guts, and therefore they may escape from the alimentary canal and be available to the soil microbial communities. Although the complete mechanism might be more complex than here represented, our dataset suggests that these factors may play an important role in enhancing microbial biosynthesis, cell proliferation and plantmicrobe symbiosis in the rhizosphere under the influence of earthworms. Lucas et al., (2016)

With the various indirect effects of vermicompost on plants, the suppression of plant diseases is one of the most significant. This is primarily related to earthworms that release coelomic fluids that kill the parasites present in the waste. Plavšin et al., (2017) showed antifungal activity of earthworm coelomic fluidextract in in vitro testing. Furthermore, Dominguez et al., Amooaghaie, and Golmohammadi (2017) observed an increase in salicylic acid and streptomycin synthesis after vermicomposting. Salicylic acid can induce plant pathogen resistance mechanisms, and antibiotic streptomycin has been shown to control bacterial diseases of fruits, vegetables and crops McManus et al., (2002). Except for the suppression of bacterial diseases, vermicompost can also suppress fungal diseases. Regarding the suppression of fungal diseases, they include the effect of vermicompost on reduced sporulation, reduced growth of pathogenic fungi and, generally, reduced infection Szczech (1999), Amooaghaie et al., (2017) reported that vermicompost is an effective biocontrol agent against Fusarium oxysporum and Phytophthora infestans. According to most of the known literature, different types of vermicompost induce higher germination rate, plant growth and yield in many plant species such as tomato Atiyeh et al., (2002) lettuce Lon`cari et al., (2005), cucumber Sallaku, et al., (2009), petunia Arancon et al., (2008), pine trees Lazcano et al., (2010) thyme Amooaghaie, and Golmohammadi (2017) begonia, sugarcane and mint Arancon et al., (2003). However, according to some data, one cannot generalize and speak exclusively about the positive effects of vermicompost Amooaghaie, and Golmohammadi (2017), Sallaku, et al., (2009). Amoogaghaie and Golmohammadi (2017) investigated the effect of various cow manure vermicompost $(25,50$, and $75 \%)$ on the germination, growth and development of thyme. Their results showed that only $25 \%$ vermicompost substitution promoted seedling emergence, while other substitutions did not have a beneficial effect. Moreover, in 50\% vermicompost substitution the maximum length, fresh and dry weight and photosynthetic efficiency were observed. Similar results 
observed Atiyeh et al., (2002) who showed that vermicompost increased seed germination and growth only to a certain amount of vermicompost substitution, while higher amounts $(100 \%)$ had negative effects, which were evident in shorter seedlings, fewer leaves and decreased germination. Ievinsh, Amooaghaie, and Golmohammadi (2017), reported that cow manure vermicompost substitution inhibited seed germination or did not have any effect that depended on the concentration of vermicompost (10-100\%) and the plant species he used. All negative effects of higher vermicompost concentrations could be due to the induced stress by the high-soluble salt concentration or phenolic compounds from vermicompost Amooaghaie, and Golmohammadi (2017).

\section{3-4 Plant Growth Promoters of Vermicompost}

Vermicompost was found to increase the growth of various vegetable, fruit, flower, and food crops not only by their macro- and microelement composition of the vermicast but also by their plant growthpromoting substances like growth hormones and enzymes. Microbes residing in the earthworm are the major contributors of such known and other unknown growth-promoting elements. Rhizobium, one of the PGP bacterium in soil that fixes nitrogen, was reported to disperse in soil by the earthworm A. trapezoids Bernard et al., 1994). Nielson (1965), report on the identification of plant growth-promoting substances in earthworms. He identified indole-like substances in the tissue extracts of A. caliginosa, L. rubellus, and E. foetida and observed enhanced growth rate of garden pea Fig. (26).

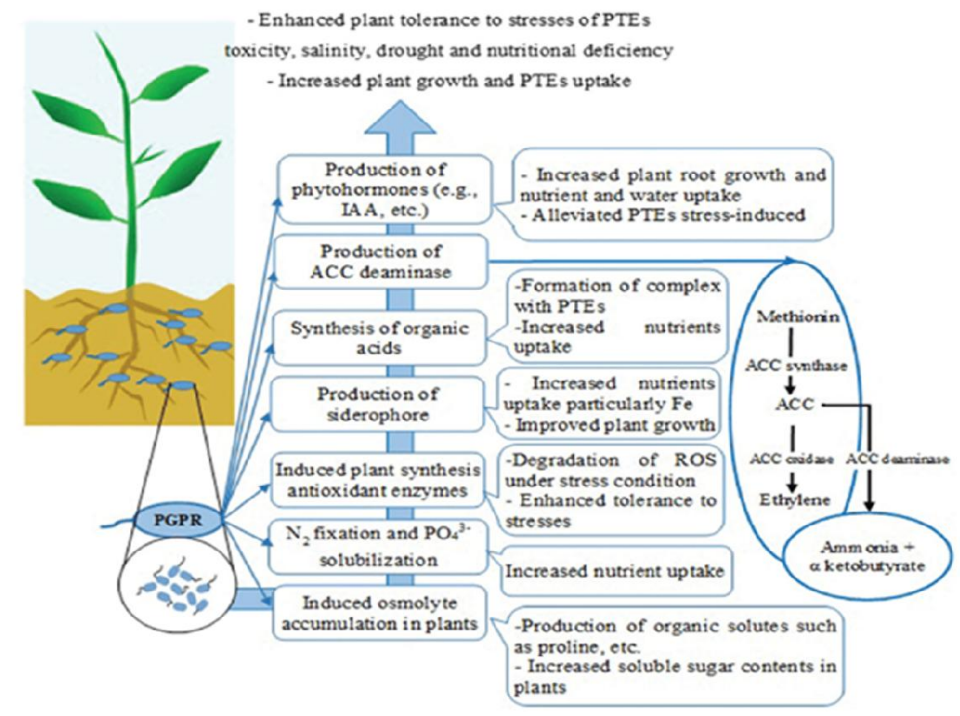

Fig. 26: Represents major mechanisms of plant growth-promoting rhizobacteria (PGPR) in improving potentially toxic elements (PTEs) phytoremediation in arid and semiarid soils. IAA: indole-3-acetic acid; ACC: 1-aminocyclopropane-1-carboxylic acid; ROS: reactive oxygen species. After Khodaverdiloo et al., (2020)

Various researchers reported substantial quantities of plant growth promoters such as auxins, gibberellins, cytokinins of microbial origin Grappelli et al., (1985), (1987); Krishnamoorthy and Vajranabhaiah (1986); Tomati et al., (1988); Muscolo et al., (1999), and humic acids Masciandaro et al., (1997); Atiyeh et al., (2002) in vermicomposts. Vermiwash (leachate), the aqueous extracts of vermicompost, is a collection of excretory compounds of earthworms and the associated microbes Fig. (27). 


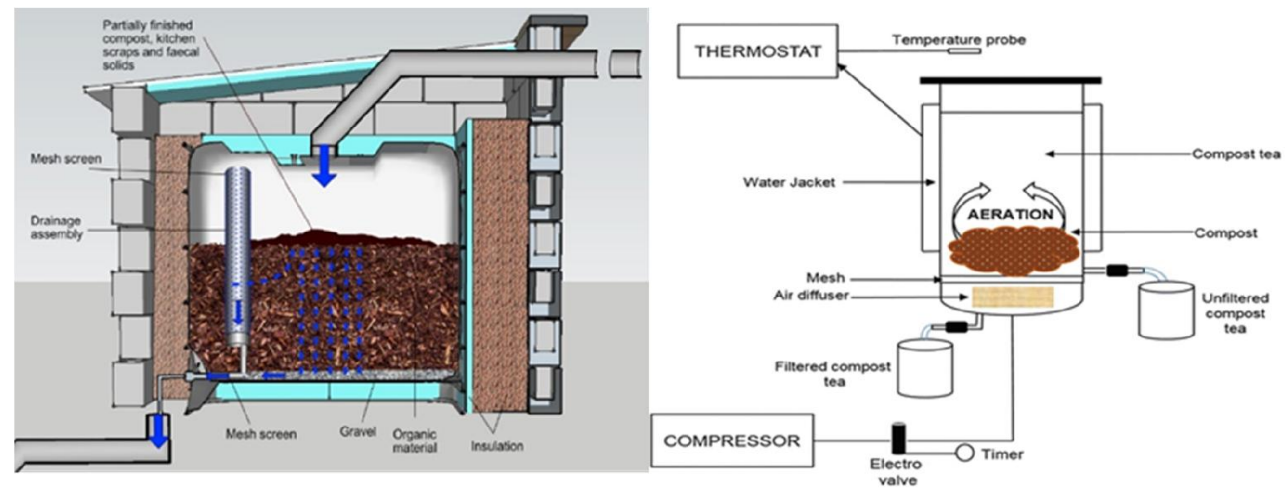

Fig. 27: Section and diagrammatic design of vermicomposting ecosystem within the toilet tank showing function of reactor producing compost tea

It serves as a fertilizer and a biocide due to the presence of macro- and micronutrients and antibiosis compounds. Hence, the use of Vermiwash also registered increased plant growth on a par with the use of hormones such as auxins, gibberellins, and cytokinins on plants such as Petunia, Begonia, and Coleus Grappelli et al., (1987); Tomati et al., (1987), (1988). Nagavallemma et al., (2004) showed a marked difference in the plumule length of maize seedlings dipped in vermiwash than normal water. Comparative studies on the impact of vermiwash and urea solution on seed germination and on root and shoot length in cluster bean, Cyamopsis tertagonoloba, demonstrated the enhanced growth in vermiwash solution that might be due to hormone-like substances Suthar (2010). HPLC and GC-MS analyses of the vermiwash of cattle waste-derived vermicompost showed the presence of significant amounts of indole acetic acid (IAA), gibberellins, and cytokinins Edwards et al., (2004). Therefore, both vermicompost and vermiwash are much rich sources of plant growth -promoting substances Fig. (28a\&b).
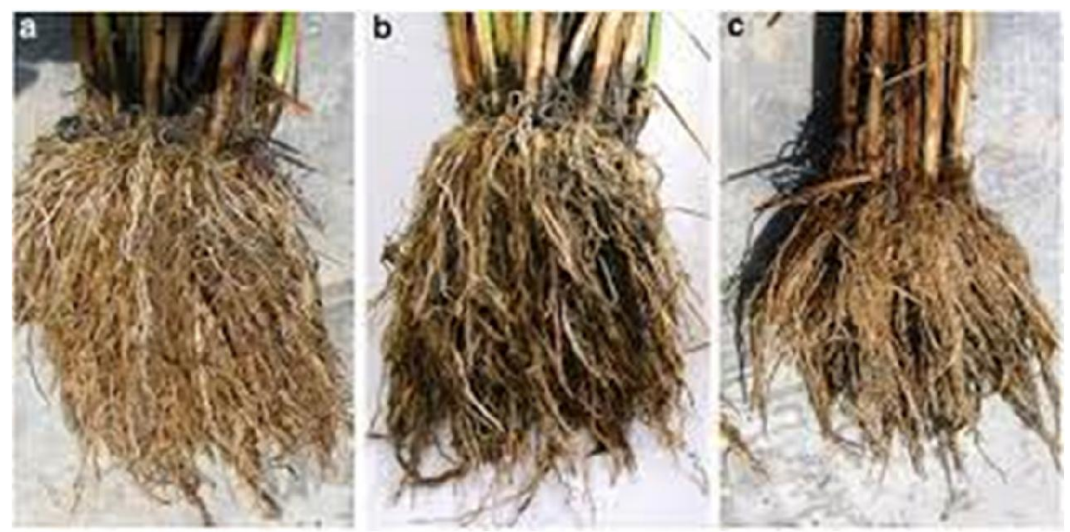

Fig. 28a: Effect of PGP actinomycetes (a) S. caviscabies and (b) S. globisporus sub sp. caucasicus on root development of rice over (c) uninoculated control. After Gopalakrishnan et al., (2014) 


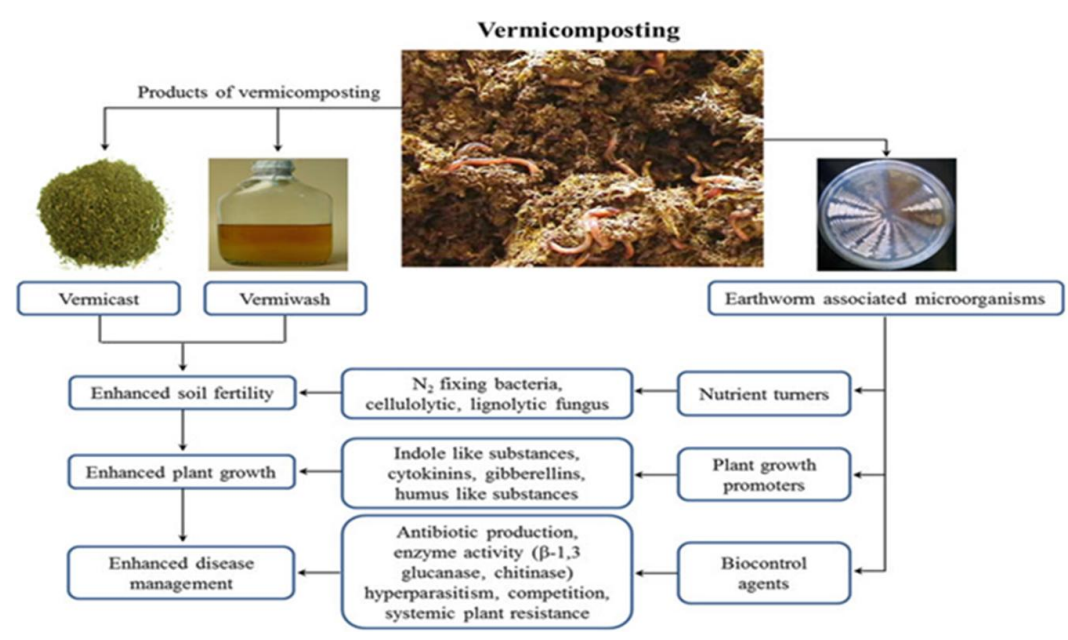

Fig. 28 b: Overview of vermicompost and its associated microbes on plant growth. After Vijayabharathi et al., (2015)

\section{3- Biocontrol Properties of Vermicompost 4-1 controlling heavy metals}

Vermicompost has positive effects on soil, plant growth and development, but some other potentially positive effects of vermicomposting and vermicompost such as remediation. It is well known that environmental contaminations are mainly caused direct or indirect effects by either industrialization or urbanization. Among the many pollutants, the most prominent ones are those caused by heavy metals (HMs) and organic ones that represent a serious problem worldwide Bhat, et al., (2018). Although there are various physical, biological and chemical methods by which these pollutants are removed from water or soil, there has been a need for less aggressive and environmentally friendly methods. As some studies have shown, vermicomposting shows some potential to become such an alternative for an environmentally friendly remediation method Shi, et al., (2019). When it comes to HMs, they are nonbiodegradable and tend to enter into food chains and bio accumulate, that can represent an escalating problem for all living organisms. Many previous studies reported a reduction of HMs after vermicomposting Goswami et al., (2014), Wang et al., (2017) Fig. (29).

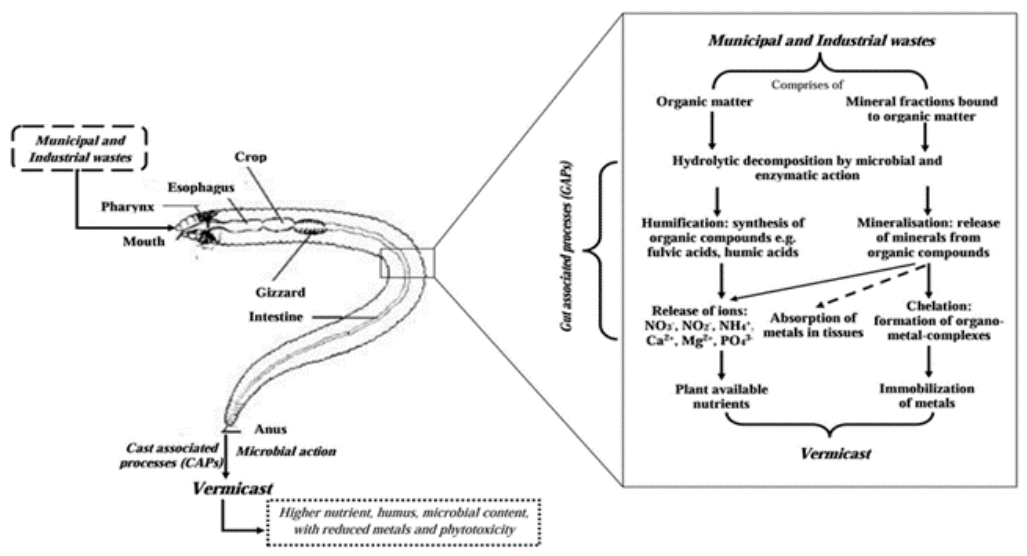

Fig. 29: Illustrates the role of earthworms and microflora during vermicomposting of various municipal and industrial wastes. After Ankita Swati and Subrata Hait (2017)

During vermicomposting, it is initially important to mention earthworms and bacteria that can influence HMs availability and bioaccumulation. Earthworms can accumulate HMs into their bodies, which is accompanied by the synthesis of metallothionein that can bind several metals such as $\mathrm{Zn}^{2+}$, $\mathrm{Cu}^{2+}$ and $\mathrm{Mn}^{2+}$ Maity et al., (2009), Lv et al., (2016) Fig. (30). 


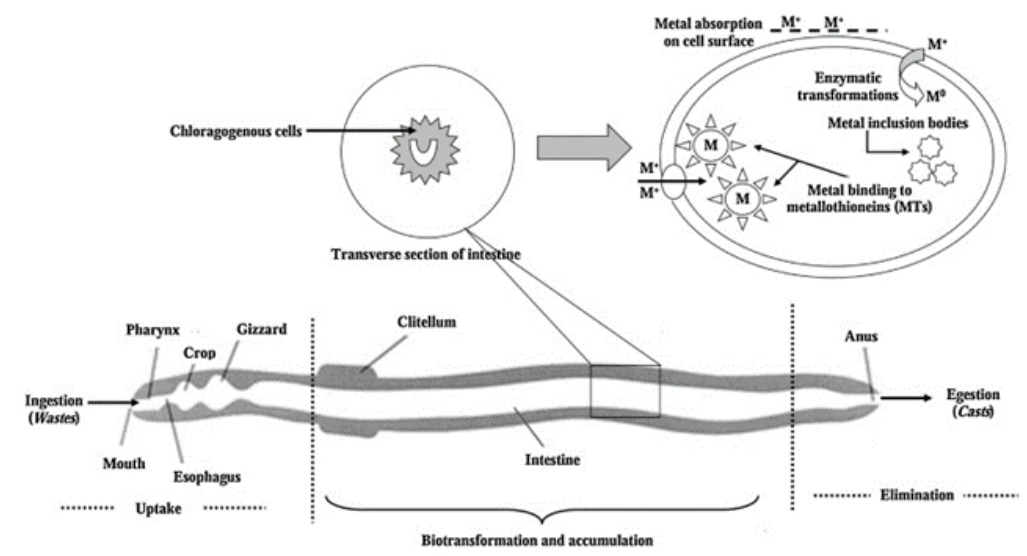

Fig. 30: Fate and bioavailability of heavy metals during vermicomposting of various organic Wastes. After Ankita Swati and Subrata Hait (2017)

Liu et al., (2012) reported that concentrations of $\mathrm{Cu}, \mathrm{Ni}, \mathrm{Cd}, \mathrm{Pb}$ and $\mathrm{Zn}$ in vermicompost decreased comparing to initial sewage sludge, while in Eisenia fetida tissues, their concentrations increased due to their adsorption. Wang et al., (2013) also observed that vermicomposting by Eisenia fetida decreased the total amount of $\mathrm{Cu}(8.3-17.2 \%), \mathrm{Zn}(5.0-8.7 \%), \mathrm{Pb}(4.9-9.8 \%), \mathrm{Cd}(7.1-15.4 \%)$ and $\mathrm{As}(1.1-9.0 \%)$ in the substrate of all treatments, as the total amount of each metal in earthworms increased. On the other hand, bacteria can also contribute to immobilization and reduce the bioaccumulation of HMs. Heavy metals have different adsorption affinities on bacteria due to electronegativity of metal ions with the affinity being higher with greater electronegativity Merdy, et al., (2009). Bacteria also have the ability to precipitate and alter oxidation states of HMs. For example, some previous studies showed that bacteria present in the soil such as Bacillus sp., Microbacterium sp., Serratia sp. and Arthrobacter sp. can reduce $\mathrm{Cr}$ (VI) to $\mathrm{Cr}$ (III) by accepting the electron via bacterial enzymatic processes. Chromium can be removed owing to different $\mathrm{Cr}$ (III) forms such as calcium chromium oxides Sedlak, and Chan (1997), Qu et al., (2018). In addition, earthworms and bacteria can directly effects on HMs during vermicomposting; they may also indirectly affect it since the ultimate characteristics of vermicompost are largely influenced by their activity. Mature vermicompost always rich in soluble salts and humic substances that can interaction with heavy metals throughout different functional groups such as - $\mathrm{NH}$, $-\mathrm{OH},-\mathrm{COOH},-\mathrm{CO}$, etc. to form organometallic complexes, furthermore García, et al., (2013), can effectively remove HMs due to carboxylic and phenolic groups as coordination sites with metal ions Chen et al., (2015). However, other functional groups also have the ability to bind metal ions. Chen et al., Chen et al., (2015), have observed that during the copper-binding process to dissolved organic matter, the carboxyl and polysaccharide groups gave the fastest responses to copper binding followed by phenolic, aryl carboxylic and small amounts of amide and aliphatic groups. Zhang et al., (2019), investigated the immobilization effect of vermicomposted sewage sludge for $\mathrm{Pb}, \mathrm{Cd}$ and $\mathrm{Cr}$ in the sediment under simulated in situ conditions, and they concluded that different humic substances formed organometallic complexes with all three HMs. According to their results, vermicompost can be used as an in situ sorbent for the remediation of sediments that are polluted with HMs. Even though there are many data about creating the complexes between humic substances and HMs, it is not completely clear, and there is no uniform model for that, especially due to the heterogeneous characters of the organic composition of vermicompost. By contrast, to all that was mentioned, there are some data about increasing HMs concentration after vermicomposting Lv et al., (2016), Bakar et al., (2011), Rorat et al., (2016). Studies that observed an increase in HMs after vermicomposting assumed that it is a result of decreased weight and volume after the breakdown of organic matter or it might be related to the excretion of worm castes coupled with HMS Bakar et al., (2011). Furthermore, Wang et al., Wang et al., (2013) concluded that some results could be explained if one considers the duration of the experiment/vermicomposting process and the time when the earthworms begin to secrete HMs into the raw material. What is not questionable is that earthworms and bacteria that are part of the vermicomposting process and changes on physicochemical properties in substrates affect the mobility and availability of HMS Lv et al., (2016). 


\section{4-2 Controlling nematode}

It has been well documented that addition of organic amendments decreases the populations of plant parasitic nematodes Addabdo (1995); Sipes et al., (1999); Akhtar and Malik (2000) Fig. (31). Vermicompost amendments appreciably suppress plant parasitic nematodes under field conditions Arancon et al., (2003b) Fig. (32).

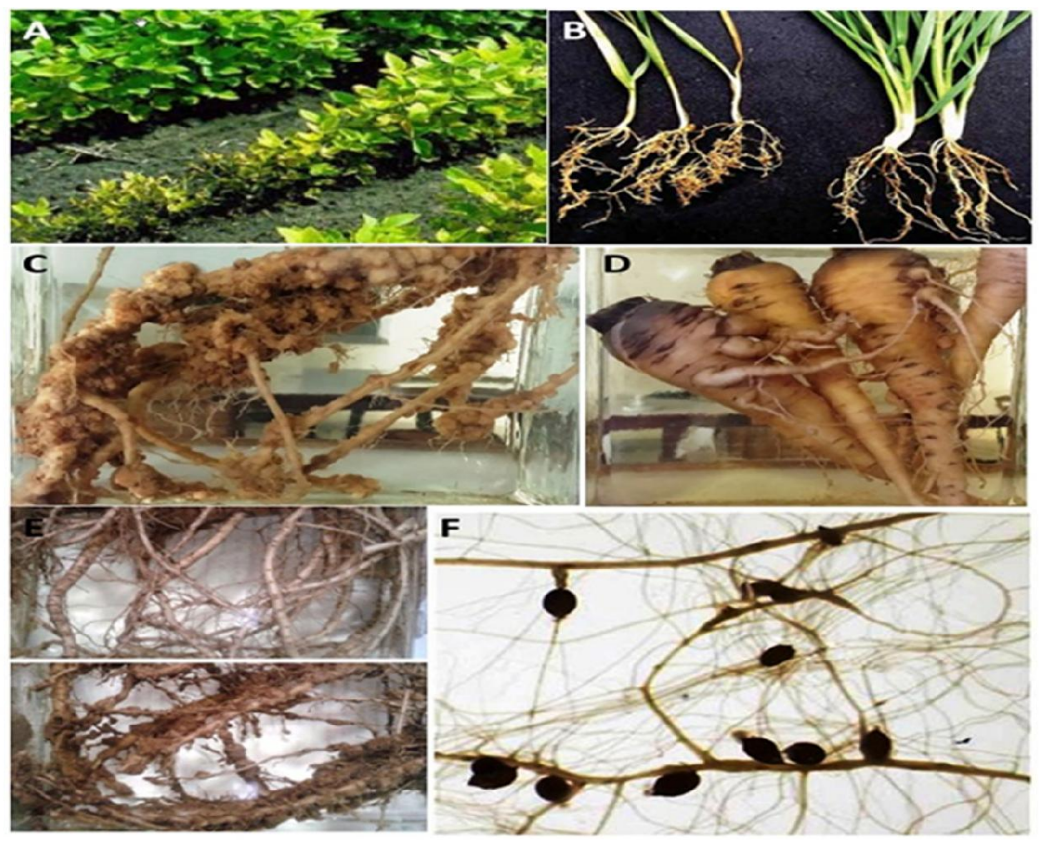

Fig. 31: Aboveground and belowground symptoms from different plant species in response to nematode infections. (A) Soybean plants infected with soybean cyst nematodes (Heterodera glycines), (B) Infected and uninfected wheat plants with cereal cyst nematode H. avenae. (C-E) Roots of sponge gourd, carrots, and okra infected with root-knot nematode Meloidogyne incognita, respectively. (F) Arabidopsis roots showing development of cysts induced by beet cyst nematode H. schachtii. After Muhammad et al., (2017).
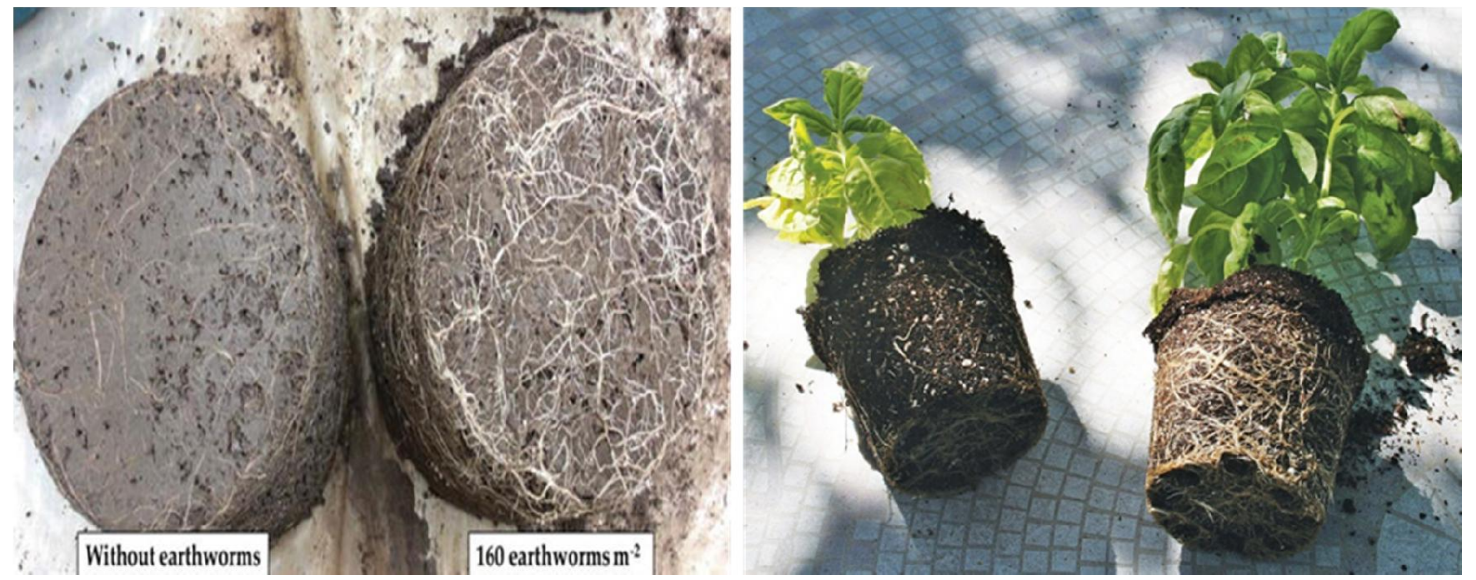

Fig. 32: Effects of earthworms on the growth of bean roots. After Jair Alves Dionísio etal. (2018)

Vermicomposts also suppressed the attack of Meloidogyne incognita on tobacco, pepper, strawberry and tomato Swathi et al., (1998); Edwards et al., (2007); Arancon et al., (2002); Morra et al., (1998) and decreased the numbers of galls and egg masses of Meloidogyne javanica Ribeiro et al., (1998). Mechanisms that mediate nematode control. There are several feasible mechanisms that 
attribute to the suppression of plant parasitic nematodes by vermicompost application and it involves both biotic and abiotic factors. Organic matter addition to the soil stimulates the population of bacterial and fungal antagonists of nematodes (e.g., Pasteuria penetrans, Pseudomonas spp. and chitinolytic bacteria, Trichoderma spp.), and other typical nematode predators including nematophagous mites viz., Hypoaspis calcuttaensis Bilgrami (1996), Collembola and other arthropods which selectively feeds on plant parasitic nematodes. Thoden et al., (2011).

Vermicompost amendment promoted fungi capable of trapping nematode and destroying nematode cysts Kerry (1988) and increased the population of plant growth-promoting rhizobacteria that produce enzymes toxic to plant parasitic nematodes Siddiqui and Mahmood (1999), Fig. (33).

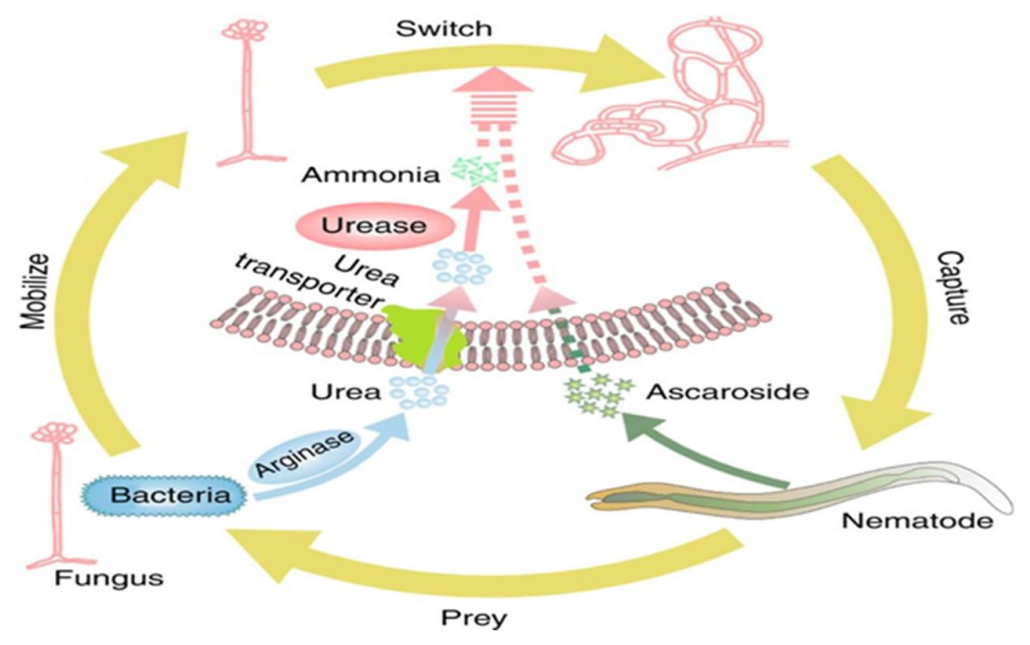

Fig. 33: A model for trap formation by nematodes and bacteria. When grazed by nematodes, bacteria increase the production and release of urea by upregulating the expression of arginase. Secreted urea is then taken up by the mycelia of nematode-trapping fungi nearby via a urea transporter, and eventually catabolized to ammonia by urease within the fungi. Ammonia in turn initiates the lifestyle switch to form trap structures. Meanwhile, ascarosides released by nematodes are transported into the mycelia of nematode-trapping fungi by unknown proteins, and induce trap formation directly. The bacteria/ureaand the nematode/ascarosidemediated signalling pathways exhibit significant synergistic effects on trap formation, resulting in the eventual capture and death of the nematodes. After Wang et al., (2014)

Vermicompost addition to soils planted with tomatoes, peppers, strawberry, grapes showed a significant reduction of plant parasitic nematodes and increased the population of fungivorous, and bacterivorous nematodes compared to inorganic fertilizer treated plots Arancon et al., (2002). In addition, few abiotic factors viz., nematicidal compounds such as hydrogen sulphide, ammonia, nitrates, and organic acids released during vermicomposting, as well as low $\mathrm{C} / \mathrm{N}$ ratios of the compost cause direct adverse effects while changes in soil physiochemical characterizes viz., bulk density, porosity, water holding capacity, $\mathrm{pH}, \mathrm{EC}, \mathrm{CEC}$ and nutrition posses indirect adverse effects on plant parasitic nematodes Rodriguez-Kabana (1986); Thoden et al., (2011).

\section{4-3 Controlling pest and diseases}

The rapid growth of the world's population requires much higher agricultural production to meet basic human needs. On the other hand, world agriculture is facing many problems in crop production, among which are plant diseases and pests Fried et al., (2017). The application of chemicals such as pesticides gives positive results concerning the control of pests, but they also cause several negative side effects such as environmental pollution, disruption of the soil's natural fertility and the destruction of beneficial organisms Fernandes et al., (2016), Aktar et al., (2009). To overcome problems of harmful organisms and diseases, in recent years, vermicompost has been mentioned as a key alternative in the fight against plant diseases, pests and pathogens, Yatoo, et al., (2021) Fig. (34), (35). 


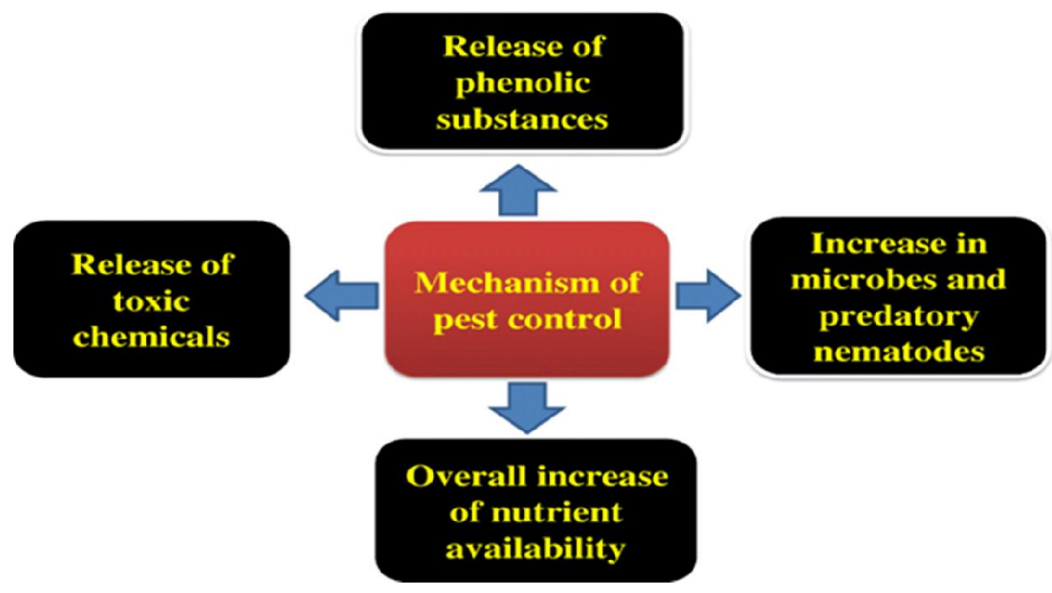

Fig. 34: Different mechanisms of disease suppression by vermicompost and vermicompost tea Vermicompost products enhance the microbial number and diversity around the root zone of the plants, and these microbes via different mechanisms protect the plants, either by stimulating resistance in plants against phytopathogens, by increasing competition for nutrients, releasing antibiotic substances against pathogens or by directly parasitizing the phytopathogens. After Ali et al., (2021)

With the various indirect beneficial effects of vermicompost on plants, the suppression of plant diseases and pests is one of the most significant. Microbial population in vermicompost acts as powerful biocontrol agents due to the production of antibiotics and secretion of extracellular enzymes such as chitinase and lipase that cause the lysis of fungal and bacterial phytopathogens.

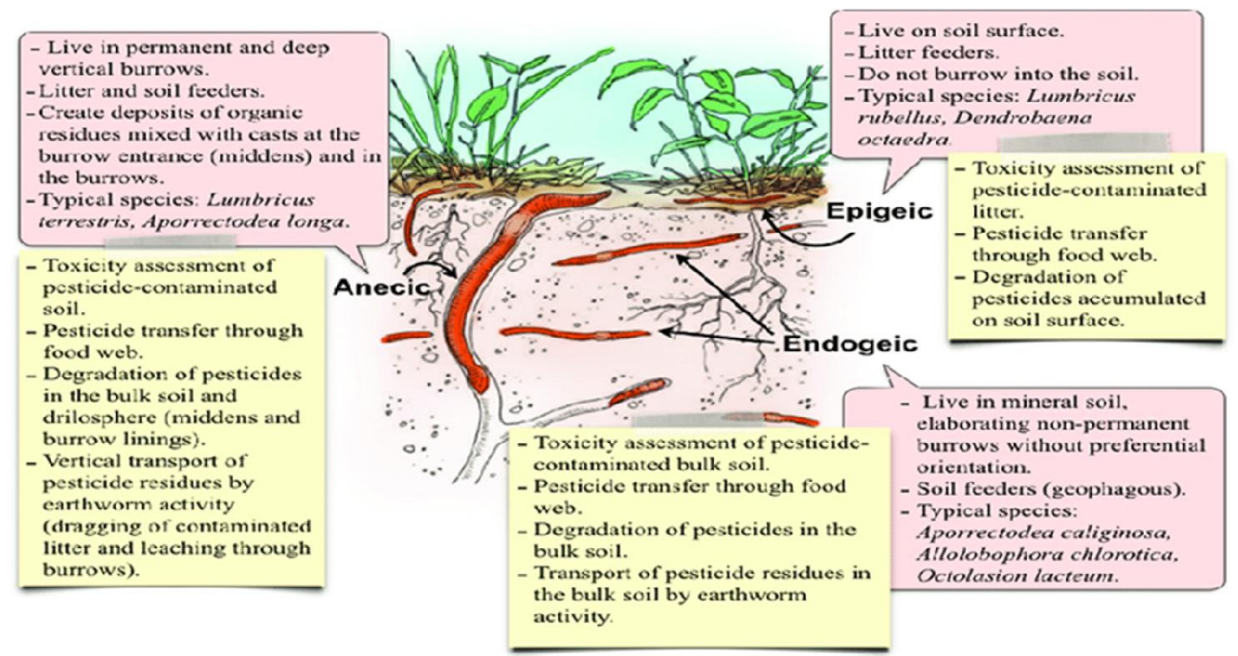

Fig. 35: Functional features (in callouts) of the three ecological groups of earthworms (epigeic, endogeic and anecic), and their potential use in pesticide ecotoxicology. After Lavelle et al., (1998).

Vermicompost is a valuable source of antagonistic bacteria and/or actinomycetes; several research reports are available to augment the biocontrol properties of vermicompost against phytopathogens such as Botrytis cineria (Singh et al., 2008), Fusarium spp. Yeates (1981); Moody et al., (1996), Gaeumannomyces spp. Clapperton et al., (2001), Rhizoctonia spp. Doube et al., (1994a); Hoitink et al., (1997); Stephens et al., (1994); Stephens and Davoren (1997), Phytophthora Ersahin et al., (2009), Plasmodiophora brassicae Nakamura (1996), and P. infestans Kostecka et al., (1996). Control of powdery mildew in barley Weltzien (1989), balsam, and pea by vermicompost application has been demonstrated under field conditions Singh et al., (2003). Pathogen control has been demonstrated in other crops like clover, cabbage, cucumber, grapes, tomatoes, radish, and strawberry Jack (2011). Besides the biocontrol properties of vermicompost, vermiwash was also found to have biocontrol traits 
against $B$. cineria, Sclerotinia sclerotiorum, Corticium rolfsii, $R$. solani, $F$. oxysporum Nakasone et al., (1999), Erysiphe cichoracearum, and E. pisi Singh et al., (2003).

Systemic plant resistance, microbial competition, antibiosis, enzyme activity, and hyperactive parasitism are the suspected reasons for pathogenic control Hoitink and Grebus (1997). Yasir et al., (2009) documented the presence of chitinolytic bacteria Nocardioides oleivorans, Streptomyces spp., and Staphylococcus epidermidis from vermicompost with inhibitory activity against phytopathogens such as R. solani, Colletotrichum coccodes, Pythium ultimum, P. capsici, and F. moniliforme. Similarly, antibiotic heliomycin-producing $S$. olivocinereus has been isolated from E. foetida's gut Polyanskaya et al., (1996). The dispersed actinomycetes from earthworms act as potential biocontrol agents against plant pathogenic fungi Doube et al., (1994a, b); Stephens et al., (1994) due to their production capacity for a wide range of secondary metabolites and antibiosis compounds. Besides pathogen control, insects or pests such as jassids, aphids, spider mites, mealy bugs, sucking pests, caterpillars, and beetles have also been controlled by vermicompost application Edwards et al., (2007); Biradar et al., (1998); Rao et al., (2001); Rao (2002), (2003) under greenhouse and field conditions.

It is important to emphasize that vermicomposting contributes not only to the reduction of plant but also human and animal pathogens. Namely, organic wastes, such as animal byproducts that can be vermicomposted and used as fertilizers, may contain pathogenic microorganisms Roubalová et al., (2020), Pachepsky et al., (2006).Roubalová et al., (2020).observed the reduction of pathogens such as Escherichia coli, Enterococcus spp., and thermo tolerant coliform bacteria in grape marc during vermicomposting. There are several possible ways by which earthworms contribute to the reduction of pathogens including bacteria, fungi and many others. They include a reduced-oxygen environment inside the gut and the presence of intestinal enzymes and coelomic fluids, which kill the parasites, present in the waste Plavšin, et al., (2017), Roubalová et al., (2020). Monroy et al., Monroy, et al., (2008), reported a decrease in the number of nematodes in a pig slurry after the passage through the earthworm's gut. The decrease occurred due to the digestion of nematodes by the proteolytic activity of enzymes present in the earthworms' gut. When it comes to coelomic fluids, it is well known that they possess antimicrobial, proteolytic, hemolytic and antifungal effects Plavšin, et al., (2017), Dales et al., (1992). Plavšin, et al., (2017), showed that coelomic fluid extracts of two earthworm species, Dendrobaena veneta and Eisenia fetida, negatively affected phytopathogenic fungi Fusarium oxysporum in vitro conditions. They concluded that earthworms might negatively affect fungal growth by ingestion and by contact as well. Although some plant pathogens are removed during earthworm digestion, vermicompost, as a final product of vermicomposting, is a true modulator not only of plant growth but also of disease and pest suppression Sarma et al., (2010). The application of vermicompost for the suppression of different soil-borne phytopathogens has grown significantly in recent years Jangra, et al., (2019), Basco, et al., (2017). Because bacterial communities change greatly during vermicomposting, vermicompost has a significantly different bacterial structure than the initial material. Vermicompost contains beneficial microorganisms such as bacteria, fungi and actinomycetes, which can improve overall plant growth, but antagonistic microorganisms, which mediate the control of diseases and pests Liu et al. (2021), Simsek et al., (2009), Liu et al., (2021) isolated 374 bacterial strains from vermicompost made from fresh cow dung of which 28 strains showed antagonistic activity against Fusarium oxysporum $f$. $s p$. cucumerinum (FOC). FOC is a fungal pathogen that causes enormous damage to cucumbers worldwide Liu et al., (2021). Similarly, suppressions of Fusarium oxysporum and Phytophthora infestans have also been reported by vermicompost treatment Domínguez, et al., (2019) Fig. (36). 

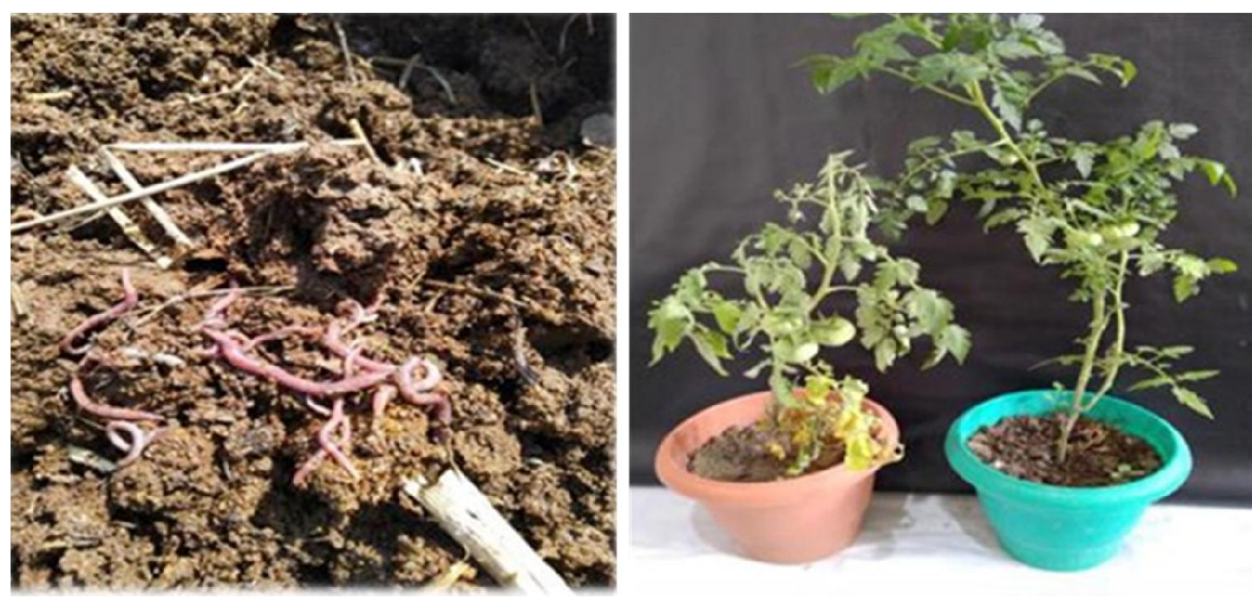

Fig. 36: Illustrates Vermicompost improves growth and reduces disease in crops. The right side pot shows higher growth and no disease symptoms in the tomato plant that was due to the addition of vermicompost, while the left side pot containing soil only (no vermicompost) shows reduced growth and disease symptom

It is important to emphasize that the influence of vermicompost on pathogens depends a lot on the type of initial substrate Szczech and Smolinska (2001).Szczech and Smolinska (2001), showed that vermicompost from animal manure reduced the infection of tomato seedlings by Phytophthora nicotianae, while vermicompost from sewage sludge did not protect seedlings from infection. The influence of vermicompost on various pathogens also depends on the type of earthworms, i.e., it depends on the morphological and physiological characteristics of the digestive system of earthworms. Bhat et al., (2018). Regarding the suppression of fungal diseases, they include the effect of vermicompost on reduced sporulation, reduced growth of pathogenic fungi and, generally, reduced infection Lores, et al., (2006), Except for the suppression of fungal diseases; vermicompost can also suppress bacterial diseases and pests. Chattopadhyay et al., (2012), observed an increase in salicylic acid and streptomycin synthesis after vermicomposting. Salicylic acid can induce plant pathogen resistance mechanisms and antibiotic streptomycin has been shown to control bacterial diseases of fruits, vegetables and crops, Bhat et al., (2018) Fig. (37). Furthermore, vermicompost can manage pests such as mites (Tetranychus urticae), mealy bugs (Pneumococcus sp.), aphids (Myzus persicae) Arancon et al., (2007), corn earworm (Helicoverpa zea). Cardoza et al., (2012), nematode (Meloidogyne incognita) Xiao et al., (2010), chili pest Polyphagotarsonemus latus Jangra, et al., (2019), etc. Arancon et al., (2007) tested the capacity of food waste vermicompost on reduction of three arthropod pests' populations and damage to cucumbers, tomatoes, bush beans, eggplants and cabbage plants.

Besides noticing the reduction in arthropod populations, pest damage and reproduction, they also noticed that vermicompost made the plants less attractive to the pests. Jangra, et al., (2019) also recorded a reduction in population, and a number of chili pest eggs after the vermicompost was applied in a rate of $5 \mathrm{t}^{-\mathrm{ha}^{-1}}$. They hypothesized that a possible reason for the suppression of pests was due to soluble micro- and macro-nutrients in vermicompost. It is correlated with the conclusion of Arancon et al., (2007) Possible mechanisms can also include the production of phenolic compounds by the plants after applications of vermicomposts, making the tissues unpalatable or even the presence of chitinase enzyme in vermicompost that helps in controlling arthropods Xiao et al., (2010), Bavaresco et al., (2007). 


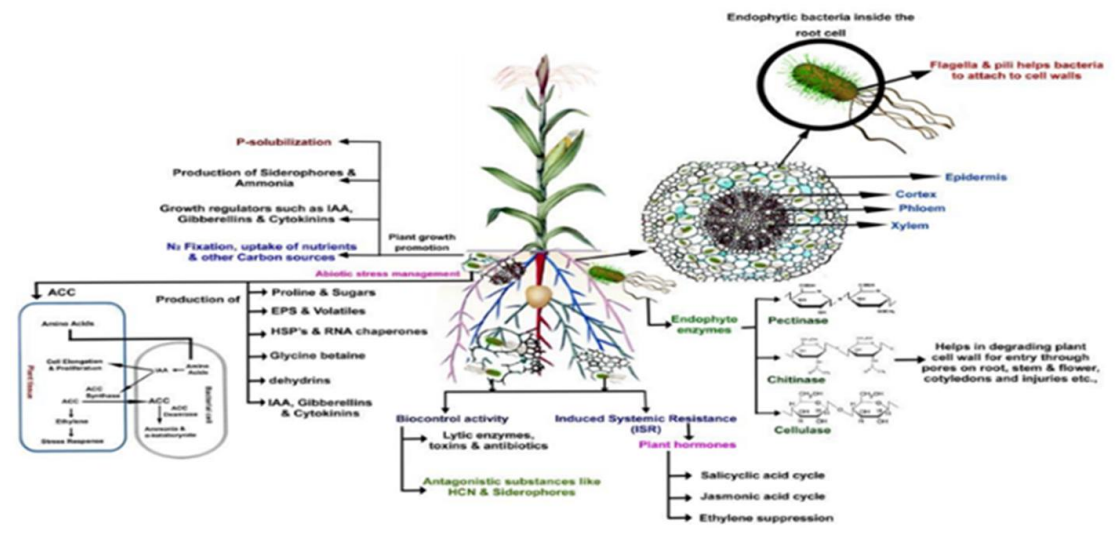

Fig. 37: Representation of possible plant-microbe interactions favouring plant growth and/or biocontrol of phytopathogens by streptomycetes as rhizosphere competent microorganisms and/or endophytes. After Vardharajula et al., (2017), Sai Shiva Krishna et al., (2018)

\section{4- Microbial Diversity of Vermicomposts}

Microbial communities including bacteria, actinomycetes, filamentous fungi, and yeast have been reported in earthworms such as L. terrestris, Allolobophora caliginosa, and A. terrestris Parle (1963 a, b), and most of them are mesophilic bacteria, fungi, and actinomycetes Benitez et al., (1999); Sen and Chandra (2009); Vivas et al., (2009). It is noticed that, earthworm's age has not showed any influence on microbial community Ferna'ndezGomez et al., (2012), but the microbial counts between the earthworm species may vary due to their different ability to digest and assimilate microbial biomass, their ecological group, food, and environmental conditions in which earthworms live Brown and Doube (2004). These factors make the vermicompost a hotspot of microbes. Unique indigenous gut-associated microflora has been documented in E. foetida Toyota and Kimura (2000), Fig. (38).

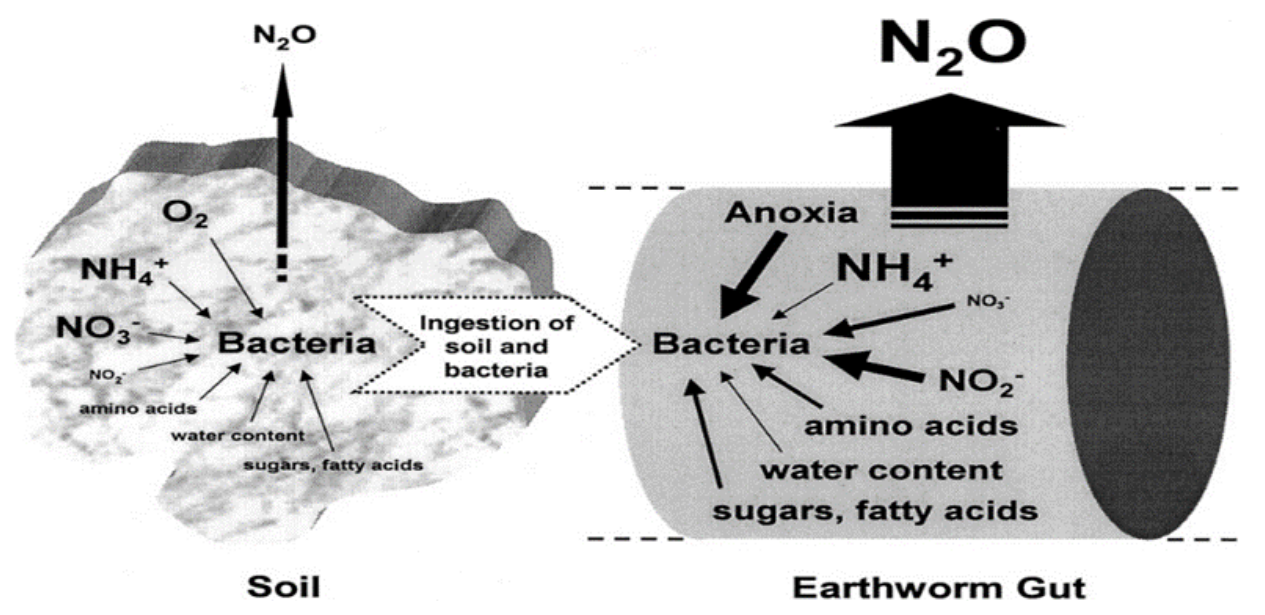

Fig. 38: Hypothetical model illustrating which factors stimulate the production of $\mathrm{N} 2 \mathrm{O}$ by bacteria ingested into the gut of the earthworm. The relative concentrations of compounds are indicated by the font sizes, and the relative effect of each compound on the production of $\mathrm{N} 2 \mathrm{O}$ in the gut is indicated by the thickness of the arrow. After Marcus et al., (2003)

In contrary, microbes living in traditional compost undergo a selection process during the heating phase, where specially adapted thermophilic bacteria Dees decompose the organic material and Ghiorse (2001). The microbial community that resides in the finished traditional compost are the facultative thermophiles, which form spores during the hot phase and recolonize during the mesophilic stage. Microbial count in the ingested material of earthworms can be increased up to 1,000-fold while passing through their gut Edwards and Fletcher (1988). Devi et al., (2009) have given a distinction on the 
microbial count of vermicomposts and of normal composts of fruit and vegetable waste, cow dung, and groundnut husk for bacteria, fungi, and actinomycetes. Many research, Pedersen and Hendriksen (1993), Devliegher and Verstraete (1995) have given a similar trend of supporting evidence. Microbial biomass and activity were also significantly increased in vermicasts over composts Brown and Doube (2004), Aira et al., (2006), Monroy et al., (2009). Earthworms' interaction with physical, chemical, and biological components affects the structural features of the microflora and micro fauna in vermicompost Domi'nguez et al., (2003); Lores et al., (2006), Monroy et al., (2009) Fig. (39).

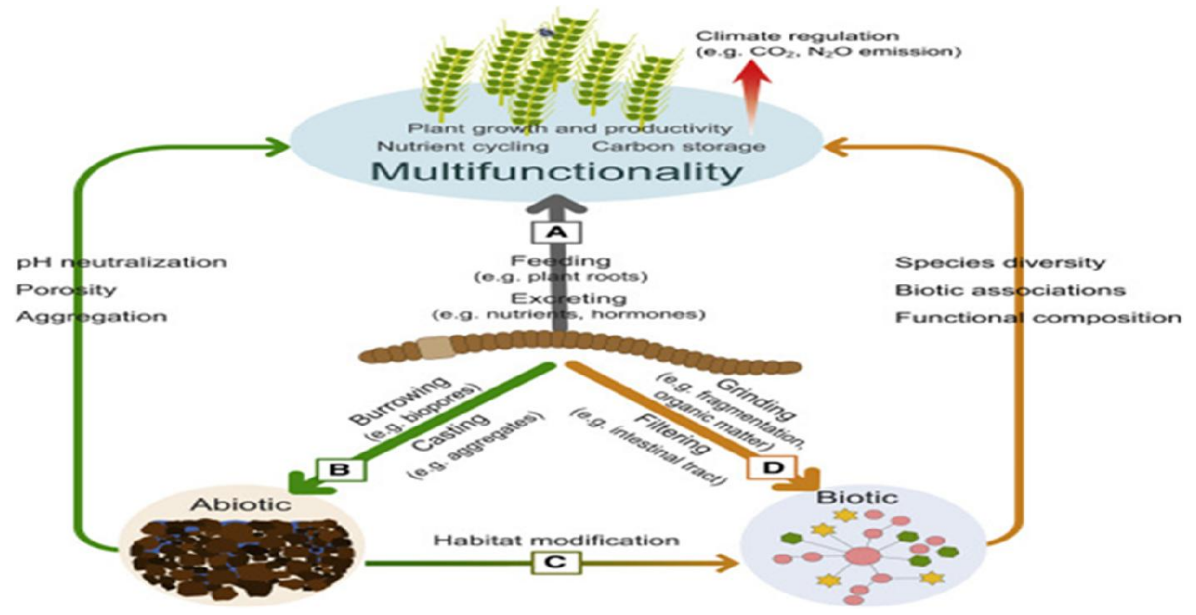

Fig. 39: Conceptual Framework Showing the Pathways of Earthworm Contributions to Ecosystem Multifunctionality, Among the pathways, (A) indicates the direct effect of earthworms and (B)-(D) are the indirect effects of earthworms mediated by soil abiotic properties through burrowing and casting activities or biological communities through grinding and filtering processes. All of these effects occur simultaneously during earthworm activities.

A recent study by Huang et al., (2013) on the bacterial communities of the earthworm E. foetida showed different phyla including Bacteroidetes, Firmicutes, Actinomycetes, Chlorobi, Planctomycetes, and Proteobacteria in vegetable waste compost, in which Bacteroidetes were predominant. Enrichment of Bacteroidetes (anaerobic group of microorganisms) in the vermicompost is probably due to the anaerobic conditions in the earthworm's gut Karsten and Drake (1995). In contrast, Pathma and Sakthivel (2013) noticed Bacillus as the dominating genus followed by Pseudomonas and Microbacterium in goat manure compost. Bacterial diversity analysis of commercial composts (poultry litter, sewage sludge, and municipal solid waste) and homemade composts (vermicompost from food wastes) has been registered with the groups such as Firmicutes: Bacillus benzoevorans, B. cereus, $B$. licheniformis, B. megaterium, B. pumilus, B. subtilis, and B. macroides; Actinobacteria: Cellulosimicrobium cellulans, Microbacterium spp., and M. oxydans; Proteobacteria: Pseudomonas spp. and P. libaniensis; ungrouped genotypes: Sphingomonas spp. and Kocuria palustris; and yeasts: Geotrichum spp. and Williopsis californica Vaz-Moreira et al., (2008). Fischer et al., (1995) observed variations in the bacterial community of vermicasts and guts (including foregut, midgut, and hindgut) of earthworms in which the bacterial count of $\alpha, \beta$, and $\gamma$ subgroups of proteobacteria increased significantly toward the end of the gut and remained high in the cast. Among the subgroups, $\alpha-$ proteobacteria was higher in the hindgut and casts, and $\beta$ - and $\gamma$ - proteobacteria were predominant in the for eand hindgut. Similar studies conducted by Nechitaylo et al., (2010) revealed the presence of Bacteroidetes, Alphaproteobacteria, Betaproteobacteria, and representatives of classes Flavobacteria, Sphingobacteria (Bacteroidetes), Pseudomonas spp., and unclassified Sphingomonadaceae (Alphaproteobacteria) and Alcaligenes spp. (Betaproteobacteria) in earthworm (L. terrestris and A. caliginosa), casts, and soil. In addition to bacteria, several studies have also been reported for fungal diversity in vermicompost and earthworms. The phyla of Saccharomycetes, Lecanoromycetes, and Tremellomycetes dominated in the initial substrate of vermicompost Bonito et al., (2010). The compost without earthworm was reported to have less fungal diversity, whereas during earthworm treatment, the 
fungal diversity has increased with Sordariomycetes, followed by Agaricomycetes, Pezizomycetes, Eurotiomycetes, Saccharomycetes, and Orbiliomycetes Bonito et al., (2010); Huang et al., (2013). Besides this, other beneficial fungi in the vermicompost have also been noticed and some of the identified populations include Paecilomyces spp. and Dactylaria biseptata Siddiqui and Mahmood (1996), Cephaliophora tropica Morikawa et al., (1993), and Trichoderma spp. Harman (2006). A study by Anastasi et al., (2005) also revealed the differentiation of fungal diversity in compost and vermicompost. Among the 194 fungal species isolated, 66 were common to both the compost and vermicompost, whereas 118 were obtained from compost and 142 from vermicompost. This concludes that fungal diversity is found more in vermicompost than in compost. Next to bacteria, actinomycetes are the major gut flora of earthworm and have been reported widely in the literature Parle (1963a, b); Ravasz et al., (1987); Ravasz and Toth (1990); Jayasinghe and Parkinson (2009). It is noticed that vermicompost has higher actinomycetes than fungus in the final product, which might be due to the antagonistic activity of the former group against the latter group Jayasinghe and Parkinson (2009). For instance, Yasir et al., (2009) and Huang et al., (2013) detected Streptomyces and Rhodococcus, the genera that have the ability to kill plant pathogens from vermicompost and fresh sludge. The actinomycetes present in the form of cell aggregates or individual cells and most of them belong to Streptomyces spp., the well-known antibiotic producers Kris "tu" fek et al., (1993), (1994), (1995). Other actinomycetes such as Micromonospora spp. were also recorded Kris`tüfek et al., (1990); Polyanskaya et al., (1996). Earthworms have food preference for substances colonized by certain fungal Tiwari and Mishra (1993); Moody et al., (1995); Marfenina and Ishchenko (1997) and bacterial species (Wright (1972). Polyanskaya et al., (1996) have demonstrated their food preference for actinomycetes on $E$. foetida, which actively consumed the spores of $S$. caeruleus than other actinomycete spores. Even though a substantial quantity of actinomycetes is digested in the foregut of the earthworms, the undigested remaining actinomycetes are able to develop rapidly in the earthworms mid- and hindgut. Hence, the chances of survival for actinomycetes were found to be higher in earthworm's hindgut Kris`ü fek et al., (1992); Polyanskaya et al., (1996); Zenova et al., (1996). These ingested actinomycetes inhibit the growth of other microorganisms' particularly litter-decomposing and pathogenic fungi and Gram-positive bacteria in the earthworm's gut. This leads to the predominance of other actinomycetes and other antibiotic-resistant microorganisms and hence the biocontrol properties against various phytopathogens Doube et al., (1994a, b), Stephens et al., (1994). Though the microbial community of bacteria-fungi-actinomycetes varies with the earthworm species/vermicompost, it also depends on the initial substrate of vermicompost.

\section{5- Conclusions}

Earthworm and vermicompost are used for various purposes, such as soil improvement, waste recycling and wastewater treatment, the vermicompost composition has limitations depending on the time required for maturity and nature of feedstock materials; hence. An interesting fact of pathogen reduction during vermicomposting and on the application in the crop field requires further insights to get more benefit from Vermi technology. Also, the following aspects related to earthworms and vermicompost should be investigated, (a) the composition of vermicompost whether or not it contains toxic substrates; (b) earthworm activities from soil that generate GHG emission; and (c) and for the recovery of soil health, some other biofertilizer could be mixed as an amendment.

There is a great challenge in understanding and clarifying the mechanisms involved in the vermicomposting process. The relation between composition of bacterial communities, amount of vermicompost, effect on heavy metal content, plant pathogens, diseases, and organic waste selection. Namely, the possible application of vermicompost products certainly depends on many factors, and with their optimization, it would be possible to influence the characteristics of the final product and consequently better exploit vermicomposting process. Vermicomposting has a great potential to process a wide range of wastes produced in agriculture, food processing, sewage treatment, etc., and generate high-quality products that can have multiple uses. Vermicomposting involves the "cooperation" between earthworms and microorganisms during a very complex biological process. Vermicomposting is a cost-effective and eco-friendly waste management technology that takes the previlige of both earthworms and the associated microbes and has many advantages over traditional thermophilic composting. Vermicomposts are excellent sources of biofertilizers and their addition improves the physiochemical and biological properties of agricultural soil. Vermicomposting amplifies the diversity 
and population of beneficial microbial communities. In addition, there is a possibility of vermicompost application in pollution reduction, which is for sure a topic that should be immediately addressed. Considering that, there are still many unknowns that need to be investigated and optimized in order to use vermicompost products in the context of sustainable agriculture. Vermicomposts with excellent physio-chemical properties and buffering ability, fortified with all nutrients in plant available forms, antagonistic and plant growth-promoting bacteria are fantabulous organic amendments that act as a panacea for soil reclamation, enhancement of soil fertility, plant growth, and control of pathogens, pests and nematodes for sustainable agriculture.

\section{References}

Abdul Rahman, M.H., S. Tosiah, A.A. Aimi, N.M. Intan, M.Y. Masnira, K. Hasliana, A.S. Nur, A.A.H. Mohamad, and A.M. Rashidah, 2020. Inventory and composting of yard waste in Serdang, Selangor, Malaysia, and Heliyon 6 e04486.

Addabdo, T.D., 1995. The nematicidal effect of organic amendments: a review of the literature 19821994. Nemato, Mediterranean, 23:299-305

Adhikary S., 2012. Vermicompost, the story of organic gold: A review., Agricultural Sciences, 3:905917

Agarwal, S., R.K. Sinha, and J. Sharma, 2010.Vermiculture for sustainable horticulture: Agronomic impact studies of earthworms, cow dung compost and vermicompost vis-à-vis chemical fertilizers on growth and yield of lady's finger (Abelmoschus esculentus). In: Sinha RK et al., (Eds) Special Issue on 'Vermiculture Technology', International Journal of Environmental Engineering. Interscience Publishers, Geneva, Switzerland

Ahmad, A., Z. Aslam, K. Bellitürk, N. Iqbal, S. Naeem, M. Idrees, Z. Kaleem, M.Y. Nawaz, M. Nawaz, M. Sajjad, et al., 2021. Vermicomposting Methods from Different Wastes: An Environment Friendly, Economically Viable and Socially Acceptable Approach for Crop Nutrition: A Review. Int. J. Food Sci. Agric., 5: 58-68.

Aira, M., M. Gómez-Brandón, P. González-Porto, and J. Domínguez, 2011. Selective reduction of the pathogenic load of cow manure in an industrial-scale continuous-feeding vermireactor. Bioresource Technol., 102:9633-9637

Aira, M., F. Monroy, and J. Domı'nguez, 2006. Changes in microbial biomass and microbial activity of pig slurry after the transit through the gut of the earthworm Eudrilus eugeniae (Kinberg, 1867). Biol. Fertile Soils, 42:371-376

Aira, M., F. Monroy, and J. Dominguez, 2007. Earthworms strongly modify microbial biomass and activity triggering enzymatic activities during vermicomposting independently of the application rates of pig slurry. Sci. Total Environ., 385:252-261.

Akhtar, M., and A. Malik, 2000. Role of organic amendments and soil organisms in the biological control of plant parasitic nematodes: a review. Bioresour. Technol., 74:35-47.

Albanell, E., J. Plaixats, and T. Cabrero, 1988. Chemical changes during vermicomposting (Eisenia fetida) of sheep manure mixed with cotton industrial wastes. Biol. Fertile. Soils 6:266-269.

Albuzio, A., G. Concheri, S. Nardi, and G. Dell'Agnola, 1994. Effect of humic fractions of different molecular size on the development of oat seedlings grown in varied nutritional conditions. In: Senesi N, Miano TM (eds) Humic substances in the Global Environment and Implications on Human Health. Elsevier, Amsterdam, Netherlands, 199-204.

Ali, M.Y., A.M. Niamat, A.B. Zahoor and H. Birjees, 2021. Sustainable management of diseases and pests in crops by vermicompost and vermicompost tea. A review, Agronomy for Sustainable Development, 41: 7 .

Ali, M., A.J. Griffiths, K.P. Williams and D.L. Jones, 2007. Evaluating the growth characteristics of lettuce in vermicompost and green waste compost. Eur. J. Soil Biol. 43(Supplement 1):S316-S319.

Amooaghaie, R., and S. Golmohammadi, 2017. Effect of Vermicompost on Growth, Essential Oil, and Health of Thymus Vulgaris. Compos. Sci. Util., 25: 166-177.

Anastasi, A., G.C. Varese, and V.F. Marchisio, 2005. Isolation and identification of fungal communities in compost and vermicompost. Mycologia, 97:33-44. 
Andriuzzi, W.S., P.T. Ngo, S. Geisen, A.M. Keith, K. Dumack, T. Bolger, et al., 2016. Organic matter composition and the protist and nematode communities around anecic earthworm burrows. Biol. Fertil. Soils, 52: 91-100.

Ankita, S., and H. Subrata, 2017. Fate and bioavailability of heavy metals during vermicomposting of various organic wastes - A review, Process Safety and Environment Protection, 109: 30- 45.

Arancon, N.Q., C.A. Edwards, R. Atiyeh, and J.D. Metzger, 2004a. Effects of vermicomposts produced from food waste on the growth and yields of greenhouse peppers. Bioresour. Technol., 93:139144.

Arancon, N.Q., C.A. Edwards, P. Bierman, J.D. Metzger, S. Lee, and C. Welch, 2003a. Effects of vermicomposts to tomatoes and peppers grown in the field and strawberries under high plastic tunnels. Pedobiologia, 47:731-735.

Arancon, N.Q., C.A. Edwards, P. Bierman, C. Welch, and J.D. Metzger, 2004b. The influence of vermicompost applications to strawberries: Part 1. Effects on growth and yield. Bioresour. Technol., 93:145-153

Arancon, N.Q., C.A. Edwards, and S. Lee, 2002. Management of plant parasitic nematode populations by use of vermicomposts. In: Proceedings Brighton Crop Protection Conference - Pests and Diseases, 8(B-2): 705-716.

Arancon, N.Q., C.A. Edwards, E.N. Yardim, T.J. Oliver, R.J. Byrne, and G. Keeney, 2007. Suppression of two-spotted spider mite (Tetranychus urticae), mealy bug (Pseudococcus sp) and aphid (Myzus persicae) populations and damage by vermicomposts. Crop Prot., 26:29-39.

Arancon, N.Q., P.A. Galvis, and C.A. Edwards, 2005. Suppression of insect pest populations and damage to plants by vermicomposts. Bioresour. Technol., 96:1137-1142 Arancon NQ, Galvis P, Edwards CA, Yardim E, (2003b) The trophic diversity of nematode communities in soils treated with vermicomposts. Pedobiologia, 47:736-740.

Arancon, N.Q., S. Lee, C.A. Edwards, and R.M. Atiyeh, 2003c. Effects of humic acids and aqueous extracts derived from cattle, food and paper-waste vermicomposts on growth of greenhouse plants. Pedobiologia, 47:744-781.

Arancon, N.Q., C.A. Edwards, and P. Bierman, 2006. Influence of vermicomposts on field strawberries: Part 2. Effect on soil microbiological and chemical properties. Bioresour. Technol., 97:831- 840.

Arancon, N.Q., C.A. Edwards, R. Atiyeh, and J.D. Metzger, 2004a. Effects of vermicomposts produced from food waste on the growth and yields of greenhouse peppers. Bioresour. Technol., 93:139144.

Arancon, N., J. Van Cleave, R. Hamasaki, K. Nagata, and J. Felts, 2020. The influence of vermicompost water extracts on growth of plants propagated by cuttings. J. Plant. Nutr., 43: 176-185.

Arancon, N.Q., C.A. Edwards, A. Babenko, J. Cannon, P. Galvis, and J.D. Metzger, 2008. Influences of vermicompost, produced by earthworms and microorganisms from cattle manure, food waste and paper waste, on the germination, growth and flowering of petunias in the greenhouse. Appl. Soil Ecol., 39: 91-99.

Arancon, N.Q., S. Lee, C.A. Edwards, and R. Atiyeh, 2003. Effects of humic acids derived from cattle, food and paper-waste vermicompost's on growth of greenhouse plants. Pedobiologia, 47: 741744.

Arshad, M., and W.T.Jr. Frankenberger, 1993. Microbial production of plant growth regulators. In: Metting FB Jr (ed) Soil Microbial Ecology: Applications in Agricultural and Environmental Management. Marcell Dekker, New York, 307-347.

Asami, D.K., Y.J. Hang, D.M. Barnett, and A.E. Mitchell, 2003. Comparison of the total phenolic and ascorbic acid content of freeze-dried and air-dried marionberry, strawberry and corn grown using conventional organic and sustainable agricultural practices. J Agric Food Chem., 51:1237-1241.

Asha, A., A.K. Tripathi, and P. Soni, 2008. Vermicomposting: A Better Option for Organic Solid Waste Management. J. Hum. Ecol., 24:59-64.

Atiyeh, R.M., N.Q. Arancon, C.A. Edwards, and J.D. Metzger, 2000c. Influence of earthwormprocessed pig manure on the growth and yield of greenhouse tomatoes. Bioresour. Technol., 75:175-180.

Atiyeh, R.M., N.Q. Arancon, C.A. Edwards, and J.D. Metzger, 2001. The influence of earthwormprocessed pig manure on the growth and productivity of marigolds. Bioresour. Technol., 81:103108. 
Atiyeh, R.M., J. Dominguez, S. Subler, and C.A. Edwards, 2000a. Changes in biochemical properties of cow manure during processing by earthworms (Eisenia andrei, Bouché) and the effects on seedling growth. Pedobiologia, 44:709-724.

Atiyeh, R.M., C.A. Edwards, S. Subler, and J.D. Metzger, 2001. Pig manure vermicompost as a component of a horticultural bedding plant medium: Effects on physicochemical properties and plant growth. Bioresource Technology., 78:11-20.

Atiyeh, R.M., S. Subler, C.A. Edwards, G. Bachman, J.D. Metzger, and W. Shuster, 2000. Effects of vermicomposts and composts on plant growth in horticultural container media and soil. Pedobiologia, 44:579-590.

Atiyeh, R.M., S. Subler, C.A. Edwards, and J. Metzger, 1999. Growth of tomato plants in horticultural potting media amended with vermicompost. Pedobiologia, 43:724-728.

Atiyeh, R., S. Lee, C. Edwards, Q. Arancon, and J. Metzger, 2002. The influence of humic acids derived from earthworm processed organic wastes on plant growth. Bioresour. Technol., 84(1):714.

Atiyeh, R.M., S. Lee, C.A. Edwards, N.Q. Arancon, and J.D. Metzger, 2002. The influence of humic acids derived from earthworm. Bioresour. Technol., 84: 7-14.

Ayastuy, M.E., C. Muscolino, J.A. Fernandez, D. Belladonna, R.A. Rodriguez, L. Caro, and L.F. Hernandez, 2020. Effect of organic substrate and aqueous extract of vermicompost on nursery basil growth. Acta Hortic., 1268.

Ayyadurai, N., N.P. Ravindra, and N. Sakthivel, 2007. Functional characterization of antagonistic fluorescent pseudomonads associated with rhizospheric soil of rice (Oryza sativa L.). J Microbiol. Biotechnol., 17:919-927.

Bachman, G.R., and D.W. Edgar, 2000. Growth of magnolia virginiana liners in vermicompostamended media. Proceeding of SNA Research Conference, Southern Nursery Association, Atlanta, $65-67$.

Bajsa, O., J. Nair, K. Mathew, and G.E. Ho, 2004.Vermiculture as a tool for domestic wastewater management. Water Science and Technology. 2003; 48:125-132.

Bakar, A.A., N.Z. Mahmood, J.A.T. Da Silva, N. Abdullah, and A.A. Jamaludin, 2011. Vermicomposting of sewage sludge by Lumbricus rubellus using spent mushroom compost as feed material: Effect on concentration of heavy metals. Biotechnol. Bioprocess. Eng., 16: 1036-1043.

Baker, G., 2007. Differences in nitrogen release from surface and incorporated plant residues by two endogeic species of earthworms (Lumbricidae) in a red-brown earth soil in southern Australia. Eur. J. Soil Biol. 43: S165-S170.

Bansal, S., and K.K. Kapoor, 2000. Vermicomposting of crop residues and cattle dung with Eisenia foetida. Bioresour. Technol., 73:95-98.

Banu, J.R., S. Logakanthi, and G.S. Vijayalakshmi, 2001. Biomanagement of paper mill sludge using an indigenous (Lampito mauritii) and two exotic (Eudrilus eugineae and Eisenia foetida) earthworms. J. Environ. Biol., 22:181-185.

Barbieri, P., A. Bernardi, E. Galli, and G. Zanetti, 1988. Effects of inoculation with different strains of Azospirillum brasilense on wheat roots development. In: Klingmüller W (ed) Azospirillum IV, Genetics, Physiology, Ecology. SpringerVerlag, Berlin, 181-188.

Barea, J.M., E. Navarro, and E. Montana, 1976. Production of plant growth regulators by rhizosphere phosphate solubilizing bacteria. J. Appl. Bacteriol., 40:129-134.

Barley, K.P., 1952. Earthworms and soil fertility IV. The influence of earthworms on the physical properties of a red-brown earth. Autralian Journal of Soil Research, 10: 371-377.

Barthod, J., C. Rumpel, and M.F. Dignac, 2018. Composting with additives to improve organic amendments. A review. Agron. Sustain. Dev., 38, 17.

Bartz, M.L.C., G.G. Brown, M.G. da Rosa, O.K. Filho, S.W. James, T. Decaëns, and D. Baretta, 2014. Earthworm richness in land-use systems in Santa Catarina, Brazil. Applied Soil Ecology, 83: 5970.

Bartz, M.L.C., G.G. Brown, M. Golçalves, M. Locatelli, S.W. James, and D. Baretta, 2011. Minhocas Urobenus sp.: das matas para o plantio direto. Revista Plantio Direto, 124: 6-7.

Bartz, M.L.C., G.G. Brown, R. Orso, A.L. Mafra, and D. Baretta, 2014. The influence of land use systems on soil and surface litter fauna in the western region of Santa Catarina. Revista Ciência Agronômica, 45: 880-887. 
Bartz, M.L.C., A.C.S. da Costa, I.G. de Souza, and G.G. Brown, 2010. Micronutrients e óxidos de ferro em coprólitos de minhocas produzidos em um Latossolo Vermelho Distroférrico (Oxisol) sob diferentes sistemas de manejo. Acta Zoologica Mexicana (nueva série), No. Especial 2, 26: 261280.

Basco, M.J., K. Bisen, C. Keswani, and H.B. Singh, 2017. Biological management of Fusarium wilt of tomato using biofortified vermicompost. Mycosphere, 8: 467-483.

Bavaresco, L., S. Pezzutto, M. Gatti, and F. Mattivi, 2007. Role of the variety and some environmental factors on grape stilbenes. Vitis J. Grapevine Res., 46: 57-61.

Behr, U. and H.J. Wiebe, 1992. Relation between photosynthesis and nitrate content of lettuce cultivars. Scientia Hortic., 49:175-179.

Benitez, E., R. Nogales, C. Elvira, G. Masciandaro, and B. Ceccanti, 1999. Enzyme's activities as indicators of the stabilization of sewage sludges composting by Eisenia foetida. Bioresour. Technol., 67:297-303.

Bentz, J.A., J. Reeves, P. Barbosa, and B. Francis, 1995. Nitrogen fertilizer effect on selection, acceptance and suitability of Euphorbia pulcherrima (Euphorbiaceae) as a host plant to Bemisia tabaci (Homoptera: Aleyrodidae). Environ. Entomol., 24:40-45.

Bernal, M.P., C. Faredes, M.A. Sanchez-Monedero, and J. Cegarra, 1998. Maturity and stability parameters of composts prepared with a, wide range of organic wastes. Bioresour. Technol., 63:9199.

Bernard, M.D., M.S. Peter, W.D. Christopher, and H.R. Maarten, 1994. Interactions between earthworms, beneficial soil microorganisms and root pathogens. Appl. Soil Ecol., 1:3-10.

Bernstad, A., S. Schott, H. Wenzel, and J.J. la Cour, 2016. Identification of decisive factors for greenhouse gas emissions in comparative life cycle assessments of food waste management-An analytical review. Journal of Cleaner Production, 119:13-24.

Bescansa, P., I. Virto, O. Fernández-Ugalde, M.J. Imaz, and A. Enrique, 2010. Casting activity of Scherotheca gigas in notill Mediterranean soils: Role in organic matter incorporation and influence of aridity. Applied and Environmental Soil Science, 526934:1-6.

Bevins, C.L., and N.H. Salzman, 2011. Paneth cells, antimicrobial peptides and maintenance of intestinal homeostasis. Nat. Rev. Microbiol. 9, 356-368. doi: 10.1038/nrmicro2546

Bhat, S.A., J. Singh, and A.P. Vig, 2015. Potential utilization of bagasse as feed material for earthworm Eisenia fetida and production of vermicompost. Springerplus 4, 11.

Bhat, S.A., J. Singh, and A.P. Vig, 2018. Earthworms as Organic Waste Managers and Biofertilizer Producers. Waste Biomass Valorization, 9:1073-1086.

Bhat, S.A., S. Singh, J. Singh, S.K. Bhawana, and A.P. Vig, 2018. Bioremediation and detoxification of industrial wastes by earthworms: Vermicompost as powerful crop nutrient in sustainable agriculture. Bioresour. Technol., 252: 172-179.

Bhatnagar, R.K., and R.K. Palta, 1996. Earthworm-Vermiculture and Vermicomposting.

Bhattacharyya, P.N., and D.K. Jha, 2012. Plant growth-promoting rhizobacteria (PGPR): emergence in agriculture. World J. Microbiol Biotechnol., 28:1327-1350.

Bidlingmaier, W. and R. Gottschall, 2000. Biologische Abfallverwertung. Ulmer ISBN 3800132087 , Stuttgart (Hohenheim).

Bilgrami, A.L., 1996. Evaluation of the predation abilities of the mite Hypoaspis calcuttaensis, predaceous on plant and soil nematodes. Fund. Appl. Nematol., 20:96-98.

Binet, F., L. Fayolle, and M. Pussard, 1998. Significance of earthworms in stimulating soil microbial activity. Biol. Fertil. Soils, 27:79-84.

Binet, F., L. Fayolle, M. Pussard, J.J. Crawford, S.J. Traina, and O.H. Tuovinen, 1998. Significance of earthworms in stimulating soil microbial activity. Biol. Fertil. Soils 27: 79-84.

Bing, X., J.M. Bloemhof, T.R.P. Ramos, A.P. Barbosa-Povoa, C.Y. Wong, and J.G.A.J. van der Vorst, 2016. Research challenges in municipal solid waste logistics management. Waste Manag., 48: 584-592.

Biradar, A.P., N.D. Sunita, R.G. Teggel, and S.B. Devaradavadgi, 1998. Effect of vermicompost on the incidence of subabul psyllid. Insect- Environ., 4:55-56.

Blok, W.J., J.G. Lamers, A.J. Termoshuizen, and G.J. Bollen, 2000. Control of soil-borne plant pathogens by incorporating fresh organic amendments followed by tarping. Phytopathology, 90:253-259. 
Blouin, M., M.E. Hodson, E. Delgado, G. Baker, L. Brussaard, K.R. Butt, et al., 2013. A review of earthworm impact on soil function and ecosystem services. Eur. J. Soil Biol., 64: 161-182.

Boca Raton, F.L., C.A. Edwards, and P.J. Bohlen, 1996. Biology and ecology of earthworms. Chapman and Hall, London, 440.

Bohlen, P.J., and C.A. Edwards, 1995. Earthworm effects on $\mathrm{N}$ dynamics and soil respiration in microcosms receiving organic and inorganic nutrients. Soil Biol. Biochem., 27:341-348.

Bonito, G., O.S. Isikhuemhen, and R. Vilgalys, 2010. Identification of fungi associated with municipal compost using DNA-based techniques. Bioresour. Technol., 101:1021-1027.

Bossuyt, H., J. Six, and P.F. Hendrix, 2005. Protection of soil carbon by microaggregates within earthworm casts. Soil Biology and Biochemistry, 37: 251-258.

Bottinelli, N., V. Hallaire, S. Menasseri-Aubry, C. Le Guillou, and D. Cluzeau, 2019. Abundance and stability of belowground earthworm casts influenced by tillage intensity and depth. Soil \& Tillage Research, 106: 263-267.

Bouché, M.B., 1977. "Stratégies lombriciennes," in Soil Organisms as Components of Ecosystems, Eds U. Lohm and T. Persson (Stockholm: Ecological Bulletin), 122-132.

Bozym, M., 2012. Biologiczne przetwarzanie biodegradowalnej frakcji odpadow komunalnych i osadów ściekowych w wermikulturze. Prace Instytutu Ceramiki i Materialow Budowlanych., 5: 335-369.

Brandón, M.G., M. Aira, A.R. Kolbe, N. de Andrade, M. Pérez-Losada, and J. Domínguez, 2019. Rapid bacterial community changes during vermicomposting of grape marc derived from red winemaking. Microorganisms, 7, 473.

Brown, B.A., and M.J. Mitchell, 1981. Role of the earthworm, Eisenia fetida, in affecting survival of Salmonella enteritidis ser. Typhimurium. Pedobiologia, 22:434-438.

Brown, G.G., 1995. How do earthworms affect microfloral and faunal community diversity? Plant Soil, 170:209-231.

Brown, G.G., I. Barois, and P. Lavelle, 2000. Regulation of soil organic matter dynamics and microbial activity in the drilosphere and the role of interactions with other edaphic functional domains. Eur. J. Soil Biol., 36:177-198.

Brown, G.G., and M. Doube, 2004. Functional interactions between earthworms, microorganisms and organic matter and plants. In: Edwards CA (ed) Earthworm ecology. St. Lucie Press, Boca Raton, FL, 213-240.

Brown, G.G., B. Pashanasi, C. Villenave, J.C. Patrón, K.B. Senapati, S. Giri, et al., 1999. "Effects of earthworms on plant production in the Tropics", in Earthworm Management in Tropical Agroecosystems, eds P. Lavelle, L. Brussaard, and P. Hendrix (CABI Publishing), 87-147.

Buckalew, D.W., R.K. Riley, W.A. Yoder, and W.J. Vail, 1982. Invertebrates as vectors of endomycorrhizal fungi and Rhizobium upon surface mine soils. West Virginia Acad. Sci. Proc., $54: 1$.

Buckerfield, J.C., and K.A. Webster, 1998. Worm-worked waste boosts grape yields: prospects for vermicompost use in vineyards. Australian and New Zealand Wine Industry Journal, 13:73-76

Burge, W.D., N.K. Enkiri, and D. Hussong, 1987. Salmonella regrowth in compost as influenced by substrate. Microbial. Ecol., 14:243-253.

Butt, K.R., 1993. Utilization of solid paper mill sludge and spent brewery yeast as a feed for soil dwelling earthworms. Bioresour. Technol., 44:105-107.

Byzov, B.A., T.Y. Nechitaylo, B.K. Bumazhkin, A.V. Kurakov, P.N. Golyshin, and D.G. Zvyagintsev, 2009. Culturable microorganisms from the earthworm digestive tract. Microbiology, 78:360-368.

Byzov, B.A., V.V. Tikhonov, T.Y. Nechitailo, V.V. Deminc, and D.G. Zvyagintsev, 2015. Taxonomic Composition and Physiological and Biochemical Properties of Bacteria in the Digestive Tracts of Earthworms. Eurasian Soil Sci., 48: 268-275.

Calabi-Floody, M., J. Medina, C. Rumpel, L.M. Condron, M. Hernandez, M. Dumont, et al., 2018. Smart fertilizers as a strategy for sustainable agriculture. Advances in Agronomy., 147: 119- 157.

Canellas, L.P., F.L. Olivares, and F.A.R. Okorokova, 2002. Humic acids isolated from earthworm compost enhance root elongation, lateral root emergence and plasma membrane $\mathrm{H}$, and - ATPase activity in maize roots. Plant Physiol., 130:1951-1957.

Cardoza, Y.J., and W.G. Buhler, 2012. Soil organic amendment impacts on corn resistance to Helicoverpa zea: Constitutive or induced? Pedobiologia, 55: 343-347. [CrossRef] 
Cerda, A., A. Artola, X. Font, R. Barrena, and T.S. Gea, 2018. A composting of food wastes: Status and challenges. Bioresource, Technology, 248A:57- 67.

Chamani, E., D.C. Joyce, and A. Reihanytabar, 2008. Vermicompost Effects on the Growth and Flowering of Petunia hybrida 'Dream Neon Rose'. American- Eurasian J. Agric. and Environ. Sci., 3:506-512.

Chan, L.P.S., and D.A. Griffiths, 1988. The vermicomposting of pretreated pig manure. Biol Wastes, 24:57-69.

Chandrappa, R., and D.B. Das, 2012. Waste quantities and characteristics, solid waste management. Environ. Sci. Eng., doi:10.1007/978-3-642-28681-0_2.

Chaoui, H., C.A. Edwards, M. Brickner, S. Lee, and N. Arancon, 2002. Suppression of the plant diseases, Pythium (damping off), Rhizoctonia (root rot) and Verticillum (wilt) by vermicomposts. Proceedings of Brighton Crop Protection Conference - Pests and Diseases, II (8B-3):711-716.

Chattopadhyay, G.N., 2012. Use of vermicomposting biotechnology for recycling organic wastes in agriculture. Int. J. Recycl. Org. Waste Agric., 1, 8.

Chaudhuri, P.S., and G. Bhattacharjee, 2002. Capacity of various experimental diets to support biomass and production of Perionyx excavates. Bioresour. Technol., 82:147-150.

Chauhan, H.K., and K. Singh, 2015. Potancy of Vermiwash with Neem plant parts on the Infestation of Earias vittella (Fabricius) and Productivity of Okra (Abelmoschus esculentus) (L.) Moench. Asian Journal of Research in Pharmaceutical Sciences, 5:36-40.

Chen, W., H.A. Hoitink, A.F. Schmitthenner, and O. Touvinen, 1987. The role of microbial activity in suppression of damping off caused by Pythium ultimum. Phytopathology, 78:314-322.

Chen, Y., and T. Aviad, 1990. Effects of humic substances on plant growth. In: MacCarthy P, Clapp CE, Malcolm RL, Bloom PR (eds) Humic Substances in Soil and Crop Sciences. Selected Reading ASA and SSSA, Madison, 161-186.

Chitrapriya, K., S. Asokan, and R. Nagarajan, 2013. Estimating the level of phosphate solubilising bacteria and Azotobacter in the vermicompost of Eudrilus eugeniae and Perionyx excavates with various combinations of cow-dung and saw-dust. Int. J. Sci. Res. Pub., 3(10).

Citernesi, U., R. Neglia, A. Seritti, A.A. Lepidi, C. Filippi, G. Bagnoli, M.P. Nuti, and R. Galluzzi, 1977. Nitrogen fixation in the gastro-enteric cavity of soil animals. Soil Biol. Biochem., 9: 71-72.

Citernesi, U., R. Neglia, A. Seritti, A.A. Lepidi, C. Filippi, G. Bagnoli, M.P. Nuti, and R. Galluzzi, 1977. Nitrogen fixation in the gastro-enteric cavity of soil animals. Soil Biol Biochem 9:71-72.

Clapperton, M.J., N.O. Lee, F. Binet, and R.L. Conner, 2001. Earthworms indirectly reduce the effect of take-all (Gaeumannomyces graminis var. tritici) on soft white spring wheat (Triticium aestivum cv. Fielder). Soil Biol. Biochem., 33:1531-1538.

Clapperton, M.J., N.O. Lee, F. Binet, and R.L. Conner, 2001. Earthworms indirectly reduce the effect of take-all (Gaeumannomyces graminis var. tritici) on soft white spring wheat (Triticium aestivum cv. Fielder). Soil Biol. Biochem., 33:1531-1538.

Contreras, E., 1980. Studies on the intestinal actinomycete flora of Eisenia lucens (Annelida, Oligochaeta). Pedobiologia, 20:411-416.

Correa, J.D., M.L. Barrios, and R.P. Galdona, 2004. Screening for plant growth promoting rhizobacteria in Chamaecytisus proliferus (tagasaste), a forage tree-shrub legume endemic to the Canary Islands. Plant Soil, 266:75-84.

Costello, M.J., and M.A. Altiei, 1995. Abundance, growth rate and parasitism of Brevicoryne brassicae and Myzus persicae (Homoptera: Aphididae) on broccoli grown in living mulches. Agric. Ecosyst. Environ., 52:187-196.

Cotxarrera, L., M.I. Trillas-Gayl, C. Steinberg, and C. Alabouvette, 2002. Use of sewage sludge compost and Trichoderma asperellum isolates to suppress Fusarium wilt of tomato. Soil Biol. Biochem., 34:467-476.

Crescent, T., 2003. Vermicomposting Development alternatives (DA) sustainable livelihoods [Internet]. Available from: http://www.dainet.org/ livelihoods/default.htm [Accessed: 12 February 2020].

Cullender, T.C., B. Chassaing, A. Janzon, K. Kumar, C.E. Muller, J.J. Werner, et al., 2013. Innate and adaptive immunity interact to quench microbiome flagellar motility in the gut. Cell Host Microbe, 14: $571-581$. 
Culliney, T.W., and D. Pimentel, 1986. Ecological effects of organic agricultural practices on insect populations. Agric. Ecosyst. Environ., 15:253-256.

Curry, J.P., and G.H. Baker, 1998. Casts production and soil turnover by earthworms in soil cores from South Australian pastures. Pedobiologia, 42: 283-287.

Curry, J.P., and O. Schmidt, 2007. The feeding ecology of earthworms - A review. Pedobiologia, 50: $463-477$.

Dales, R.P., and Y. Kalaç, 1992. Phagocytic defence by the earthworm Eisenia foetida against certain pathogenic bacteria. Comp. Biochem. Physiol. Part. A Physiol., 101: 487-490.

Daniel, O., and J.M. Anderson, 1992. Microbial biomass and activity in contrasting soil material after passage through the gut of earthworm Lumbricus rubellus Hoffmeister. Soil Biol. Biochem., 24:465-470.

Darwin, F., and A.C. Seward, 1903. More letters of Charles Darwin. In: John M (ed) A record of his work in series of hitherto unpublished letters, London, 2: 508.

Dash, M.C., 1978. Role of earthworms in the decomposer system. In: Singh JS, Gopal B (eds) Glimpses of ecology. India International Scientific Publication, New Delhi, 399-406.

Deeb, M., T. Desjardins, P. Podwojewski, A. Pando, M. Blouin, and T.Z. Lerch, 2017. Interactive effects of compost, plants and earthworms on the aggregations of constructed Technosols. Geoderma, 305: 305-313.

Dees, P.M., and W.C. Ghiorse, 2001. Microbial diversity in hot synthetic compost as revealed by PCR amplified rRNA sequences from cultivated isolates and extracted DNA. FEMS Microbiol. Ecol., 35:207-216.

Dell'Agnola, G., and S. Nardi, 1987. Hormone-like effect and enhanced nitrate uptake induced by depolyconder humic fractions obtained from Allolobophora rosea and A. caliginosa faeces. Biol. Fertil. Soils, 4:111-118.

Demirbas, A., 2011. Waste management, waste resource facilities and waste conversion processes. Energy Convers. Manag., 52: 1280-1287.

Desai VR., R.N. Sabale, and P.V. Raundal, 1999. Integrated nitrogen management in wheat-coriander cropping system. J Maharasthra Agric. Univ., 24:273-275.

Devi, D., S.K. Agarwal, and D. Dayal, 1998. Response of sunflower (Helianthus annuus) to organic manures and fertilizers. Indian J. Agron., 43:469-473.

Devi, S.H., K. Vijayalakshmi, K.P. Jyotsna, S.K. Shaheen, K. Jyothi, and M.S. Rani, 2009. Comparative assessment in enzyme activities and microbial populations during normal and vermicomposting. J. Environ. Biol., 30:1013-1017.

Devliegher, W., and W. Verstraete, 1995. Lumbricus terrestris in a soil core experiment: nutrientenrichment processes (NEP) and gut-associated processes (GAP) and their effect on microbial biomass and microbial activity. Soil Biol. Biochem., 27:1573-1580.

Devliegher, W., and W. Verstraete, 1997. Microorganisms and soil physicochemical conditions in the drilosphere of Lumbricus terrestris. Soil Biol. Biochem., 29:1721-1729.

Domi'nguez, J., 2004. State-of-the-Art and new perspectives on vermicomposting research. Earthworm Ecology. Boca Raton, FL, CRC Press Domi'nguez J, Parmelee RW, Edwards CA, 2003) Interactions between Eisenia andrei (Oligochaeta) and nematode populations during vermicomposting. Pedobiologia, 47:53-60.

Domi'nguez, J., M. Aira, and M. Gomez-Brandon, 2010. Vermicomposting: earthworms enhance the work of microbes. In: Insam H, Franke-Whittle I, Goberna M (eds) Microbes at work: from wastes to resources. Springer, Berlin., 93-114.

Dominguez, J., and C.A. Edwards, 2004. Vermicomposting organic wastes: A review. In: Shakir Hanna SH, Mikhail WZA (eds) Soil Zoology for sustainable Development in the 21st century, Cairo, 369395.

Dominguez, J., C.A. Edwards, and M. Webster, 2000. Vermicomposting of sewage sludge: effects of bulking materials on the growth and reproduction of the earthworm Eisenia andrei. Pedobiologia, $44: 24-32$.

Dominguez, J., and C.A. Edwards, 2010. Relationships between composting and vermicomposting: Relative values of the products. In: Edwards CA, Arancon NQ, Sherman RL, editors. Vermiculture Technology: Earthworms, Organic Waste and Environmental Management. Boca Raton, Florida, $1-14$. 
Domínguez, J., M. Aira, A.R. Kolbe, M. Gómez-Brandón, and M. Pérez-Losada, 2019. Changes in the composition and function of bacterial communities during vermicomposting may explain beneficial properties of vermicompost. Sci. Rep., 9: 9657.

Doube, B.M., M.H. Ryder, C.W. Davoren, and T. Meyer, 1995. Earthworms: a down under delivery system service for biocontrol agents of root disease. Acta ZoolFennica, 196:219-223.

Doube, B.M., P. Stephens, C. Davoren, and M.H. Ryder, 1994a. Interactions between earthworms, beneficial soil microorganisms and root pathogens. Appl. Soil Ecol., 1:3-10.

Doube, B.M., P.M. Stephens, C.W. Davoren, and M.H. Ryder, 1994b. Earthworms and the introduction and management of beneficial soil microorganisms. In: Pankhurst CE, Doube DM, Gupta VVSR, Grace PR (eds) Soil biota: management in sustainable farming systems. 46 CSIRO Information, Melbourne, 32-41.

Dumontet, S., H. Dinel, and S.B. Baloda, 1999. Pathogen Reduction in Sewage Sludge by Composting and Other Biological Treatments: A Review. Biol. Agric. Hortic., 16: 409-430.

Eastman, B.R., 1999. Achieving pathogen stabilization using vermicomposting. BioCycle, 40:62-64.

Edwards, C.A., 1988. Breakdown of animal, vegetable and industrial organic wastes by earthworms. In: Edwards CA, Neuhauser EF (eds) Earthworms in Waste and Environmental Management SPB. The Hague, Netherlands, 21-31.

Edwards, C.A., 1998. The use of earthworms in the breakdown and management of organic wastes. In: Edwards CA (ed) Earthworm Ecology. CRC Press, Boca Raton, 327-354.

Edwards, C.A., 2011. Human pathogen reduction during vermicomposting. In: Edwards CA, Arancon NQ, Sherman R (eds) Vermiculture technology: earthworms, organic wastes and environmental management. CRC Press, Boca Raton, 249-261.

Edwards, C.A., and N.Q. Arancon, 2004. Vermicomposts suppress plant pest and disease attacks. BioCycle, 45:51-53.

Edwards, C.A., N.Q. Arancon, M.V. Bennett, A. Askar, and G. Keeney, 2010b. Effect of aqueous extracts from vermicomposts on attacks by cucumber beetles (Acalymna vittatum) (Fabr.) on cucumbers and tobacco hornworm (Manduca sexta) (L.) on tomatoes. Pedobiologia, 53:141-148.

Edwards, C.A., N.Q. Arancon, M.V. Bennett, A. Askar, G. Keeney, and B. Little, 2010a. Suppression of green peach aphid (Myzus persicae) (Sulz.), citrus mealybug (Planococcus citri) (Risso), and two spotted spider mite (Tetranychus urticae) (Koch.) attacks on tomatoes and cucumbers by aqueous extracts from vermicomposts. Crop Prot., 29:80-93.

Edwards, C.A., N.Q. Arancon, E. Emerson, and R. Pulliam, 2007. Suppressing plant parasitic nematodes and arthropod pests with vermicompost teas. Biocycle, 48:38-39.

Edwards, C.A., and P.J. Bohlen, 1996. Biology and Ecology of earthworms. Chapman and Hall, London, 426.

Edwards, C.A., I. Burrows, 1988. The potential of earthworm composts as plant growth media. In: Edwards CA, Neuhauser E (eds) Earthworms in Waste and Environmental Management. SPB Academic Press, The Hague, 21-32.

Edwards, C.A., I. Burrows, K.E. Fletcher, and B.A. Jones, 1985. The use of earthworms for composting farm wastes. In: Gasser JKR (ed) Composting Agricultural and Other Wastes. Elsevier, London, 229-241.

Edwards, C.A., J. Dominguez, and N.Q. Arancon, 2004. The influence of vermicomposts on pest and diseases. In: Hanna SHS, Mikhail WZA (eds) Soil zoology for sustainable development in the 21st century. S. H. Shakir Hanna, Cairo, 397-418.

Edwards, C.A., J. Dominguez, and N.Q. Arancon, 2004. The influence of vermicomposts on pest and diseases. In: Shakir Hanna SH, Mikhail WZA (eds) Soil Zoology for Sustainable Development in the 21 st centuary, Cairo, 397-418.

Edwards, C.A., J. Dominguez, and E.F. Neuhauser, 1998. Growth and reproduction of Perionyx excavatus (Perr.) (Megascolecidae) as factors in organic waste management. Biol Fertil Soils, 27:155-161.

Edwards, C.A., and K.E. Fletcher, 1988. Interaction between earthworms and microorganisms in organic matter breakdown. Agric. Ecosyst. Environ., 20:235-249.

Edwards, C.A., and R. Lofty, 1977. The Biology of Earthworms. Chapmann and Hall, London Elmer WH, 2009) Influence of earthworm activity on soil microbes and soilborne diseases of vegetables. Plant Dis., 93:175-179. 
Ehlers, W., 1975. Observations on earthworms' channels and infiltration on tilled and untilled loess soil. Soil Science, 119: 242-249.

Elvira, C., J. Dominguez, L. Sampedro, and S. Mato, 1995. Vermicomposting for the pulp industry. Biocycle, 36:62-63.

Elvira, C., L. Sampedro, E. Benítez, and R. Nogales, 1998. Vermicomposting of sludges from paper mill and dairy industries with Eisenia andrei: a pilot-scale study. Bioresour Technol., 63:205-211.

Elvira, C., L. Sampedro, J. Dominguez, and S. Mato, 1997. Vermicomposting of wastewater sludge from paper-pulp industry with nitrogen rich materials. Soil Biol. Biochem., 9:759-762.

Elvira, C., M. Goicoechea, L. Sampedro, S. Mato, and R. Nogales, 1996. Bioconversion of solid paperpulp mill sludge by earthworms. Bioresour. Technol., 1(57): 173-177.

Ermund, A., J.K. Gustafsson, G.C. Hansson, and A.V. Keita, 2013. Mucus properties and goblet cell quantification in mouse, rat and human ileal Peyer's patches. PLoS ONE 8:e83688.

Ersahin, Y.S., K. Haktanir, and Y. Yanar, 2009. Vermicompost suppresses Rhizoctonia solani Ku“hn in cucumber seedlings. J. Plant Dis. Prot., 9:15-17.

Escobar-Gutierrez, A.J., I.G. Burns, A. Lee, and R.N. Edmondson, 2002. Screening lettuce cultivars for low nitrate content during summer and winter production. J. Hortic. Sci. Biotechnol., 77:232-237.

Evans, A.C., 1948. Some effects of earthworms on soil structure. Annals of Applied Biology, 35: 1-13.

Ferna'ndez-Gomez, M.J., R. Nogales, H. Insam, E. Romero, and M. Goberna, 2012. Use of DGGE and COMPOCHIP for investigating bacterial communities of various vermicomposts produced from different wastes under dissimilar conditions. Sci. Total Environ., 414:664-671.

Fernandes, M.E.S., F.M. Alves, R.C. Pereira, L.A. Aquino, F.L. Fernandes, and J.C. Zanuncio, 2016. Lethal and sublethal effects of seven insecticides on three beneficial insects in laboratory assays and field trials. Chemosphere, 156: 45-55.

Ferreras, L., E. Gomez, S. Toresani, I. Firpo, and R. Rotondo, 2006. Effect of organic amendments on some physical, chemical and biological properties in a horticultural soil. Bioresour. Technol., 97:635-640.

Ferronato, N., E.C. Rada, M.A. Gorritty Portillo, L.I. Cioca, M. Ragazzi, and V. Torretta, 2019. Introduction of the circular economy within developing regions: A comparative analysis of advantages and opportunities for waste valorization. J. Environ. Manag. 230: 366-378.

Fischer, K., D. Hahn, O. Daniel, J. Zeyer, and R.I. Amann, 1995. In situ analysis of the bacterial community in the gut of the earthworm Lumbricus terrestris L. by whole-cell hybridization. Can J. Microbiol., 41:666-673.

Fokion, P., P. Ioannis, T. Ioannis and T. Efstathios, 2012. Vermicompost as a soil supplement to improve growth, yield and quality of lettuce (Lactuca sativa L.), Journal of Food, Agriculture \& Environment, 10(2): 677-682.

Fracchia, L., A.B. Dohrmann, M.G. Martinotti, and C.C. Tebbe, 2006. Bacterial diversity in a finished compost and vermicompost: differences revealed by cultivation independent analyses of PCRamplified 16S rRNA genes. Appl. Microbiol. Biotechnol, 71:942-952.

Fragoyiannis, D.A., R.G. McKinlay, and J.P.F. D’Mello, 2001. Interactions of aphids herbivory and nitrogen availability on the total foliar glycoalkoloid content of potato plants. J. Chem. Ecol., 27:1749-1762.

Fried, G., B. Chauvel, P. Reynaud, and I. Sache, 2017. Decreases in Crop Production by Non-native Weeds, Pests, and Pathogens. In Impact of Biological Invasions on Ecosystem Services; Springer: Cham, Switzerland. [CrossRef]

Furlong, M.A., D.R. Singleton, D.C. Coleman, and W.B. Whitman, 2002. Molecular and culture-based analyses of prokaryotic communities from an agricultural soil and the burrows and casts of the earthworm Lumbricus rubellus. Appl. Environ. Microbiol., 68:1265-1279.

Gajalakshmi, S., E.V. Ramasamy, and S.A. Abbasi, 2001. Assessment of sustainable vermiconversion of water hyacinth at different reactor efficiencies employing Eudrilus engeniae Kingburg. Bioresour. Technol., 80:131-135.

Gajalakshmi, S., E.V. Ramasamy, and S.A. Abbasi, 2002. Vermicomposting of paper waste with the anecic earthworm Lampito mauritii Kingburg. Indian J. Chem. Technol., 9:306-311.

Gammack, S.M., E. Paterson, J.S. Kemp, M.S. Cresser, and K. Killham, 1992. Factors affecting movement of microorganisms in soils. In: Stotzky G, Bolla LM (eds) Soil Biochemistry, 7. Marcel Dekker, New York, 263-305. 
Gandhi, M., V. Sangwan, K.K. Kapoor, and N. Dilbaghi, 1997. Composting of household wastes with and without earthworms. Environ. Ecol., 15:432-434.

Ganesh, K.A., and G. Sekaran, 2005. Enteric pathogen modification by anaecic earthworm, Lampito Mauritii. J. Appl. Sci. Environ. Mgt., 9:15-17.

Gange, A.C., 1993. Translocation of mycorrhizal fungi by earthworms during early succession. Soil Biol. Biochem., 25:1021-1026.

Garcia, C., T. Hernandez, and F. Costa, 1997. Potential use of dehydrogenase activity as an index of microbial activity in degraded soils. Commun Soil Sci. Plant Anal., 28:123-134.

García, A.C., F.G. Izquierdo, N.M.B.D.A. Sobrinho, R.N. Castro, L.A. Santos, L.G.A. De Souza, and R.L.L. Berbara, 2013. Humified insoluble solid for efficient decontamination of nickel and lead in industrial effluents. J. Environ. Chem. Eng., 1: 916-924.

Garg, P., A. Gupta, and S. Satya, 2006. Vermicomposting of different types of waste using Eisenia foetida: a comparative study. Bioresour, Technol., 97:391-395.

Gavrilov, K., 1963. Earthworms, producers of biologically active substances. Zh. Obshch. Biol., 24:149-154.

Gerrit, A., W.M. Carsten, P. Isabel, A. Šárka, F. Jan, J. Veronika, P. Francien and G.J.N. Klaas, 2019. Earthworms act as biochemical reactors to convert labile plant compounds into stabilized soil microbial necromass, Communications Biology | https://doi.org/10.1038/s42003-019-0684-z

Gholami, H., A. Ghani, F.F. Raouf, M.J. Saharkhiz, and H. Hazrati, 2019. Changes in photosynthetic pigments and uptake of some soil elements by chicory supplied with organic fertilizers. Acta Ecol. Sin., 39: 250-256.

Ghosh, M., G.N. Chattopadhyay, and K. Baral, 1999. Transformation of phosphorus during vermicomposting. Bioresour. Technol., 69:149-154.

Ghosh, M., G.N. Chattopadhyay, K. Baral, and P.S. Munsi, 1999. Possibility of using vermicompost for reconciling sustainability with productivity. In: Ghosh DC (ed) Proceedings sem. agrotechnology and environment, Visva-Bharati University, India, 64-68.

Gianquinto, G.P., M. Borin, and A. Scaife, 1992. Nitrate content in vegetable crops as affected by soil characteristics, rate and type of fertilization. Proceedings of the second Congress of the European Society for Agronomy, 256-257.

Gliotti, C., P.L. Giusquiani, D. Businelli, and A. Machioni, 1997. Composition changes of dissolved organic matter in a soil amended with municipal waste compost. Soil Sci., 162:919-926.

Goenadi, D.H., and I.M. Sudharama, 1995. Shoot initiation by humic acids of selected tropical crops grown in tissue culture. Plant Cell Rep., 15:59-62.

Goldstein, J., 1998. Compost suppresses diseases in the lab and fields. BioCycle, 39:62-64.

Gopal, M., A. Gupta, E. Sunil, and V.G. Thomas, 2009. Amplification of plant beneficial microbial communities during conversion of coconut leaf substrate to vermicompost by Eudrilus sp. Curr. Microbiol., 59:15-20

Gopalakrishnan, S., P. Humayun, V.S. Srinivas, R. Vijayabharathi, R.K. Bhimineni, O. Rupela, 2012. Plant growth-promoting traits of Streptomyces with biocontrol potential isolated from herbal vermicompost. Biocontrol Sci. Technol., 22:1199-1210.

Gopalakrishnan, S., I.G.K. Kannan, G. Alekhya, P. Humayun, S.V. Meesala, and D. Kanala, 2010. Efficacy of Jatropha, Annona and Parthenium biowash on Sclerotium rolfsii, Fusarium oxysporum f. sp. ciceri and Macrophomina phaseolina, pathogens of chickpea and sorghum. Afr. J. Biotechnol., 9: 8048-8057.

Gopalakrishnan, S., B.K. Kiran, P. Humayun, M.S. Vidya, K. Deepthi, S. Jacob, S. Vadlamudi, G. Alekhya, and O. Rupela, 2011a. Biocontrol of charcoal-rot of sorghum by Actinomycetes isolated from herbal vermicompost. Afr. J. Biotechnol., 10:18142-18152.

Gopalakrishnan, S., S. Pande, M. Sharma, P. Humayun, B.K. Kiran, D. Sandeep, M.S. Vidya, K. Deepthi, and O. Rupela, 2011b. Evaluation of actinomycete isolates obtained from herbal vermicompost for the biological control of Fusarium wilt of chickpea. Crop Prot., 30:1070-1078.

Gopalakrishnan, S., R.G.V. Ranga, K.B. Ratna, R. Vijayabharathi, C. Srinivas, C.L.L. Gowda, 2013a. Development of broad-spectrum actinomycetes for biocontrol and plant growth promotion of food crops. Recent advances in biofertilizers and biofungicides (PGPR) for sustainable agriculture. In: Proceedings of 3rd Asian conference on plant growth-promoting rhizobacteria (PGPR) and other microbials, Manila, Philippines, 21-24. 
Gopalakrishnan, S., R.G.V. Ranga, P. Humayun, V.R. Rao, G. Alekhya, S. Jacob, K. Deepthi, M.S. Vidya, V. Srinivas, L. Mamatha, and O. Rupela, 2011c. Efficacy of botanical extracts and entomopathogens on control of Helicoverpa armigera and Spodoptera litura. Afr. J. Biotechnol., 10:16667-16673.

Gopalakrishnan, S., S. Vadlamudi, S. Apparla, P. Bandikinda, R. Vijayabharathi, R.K. Bhimineni, and O. Rupela, 2013b. Evaluation of Streptomyces spp. for their plant growth promotion in rice. Can. J. Microbiol., 59:534-539.

Gopalakrishnan, S., S. Vadlamudi, P. Bandikinda, A. Sathya, R. Vijayabharathi, O. Rupela, H. Kudapa, K. Katta, and R.K. Varshney, 2014. Evaluation of Streptomyces strains isolated from herbal vermicompost for their plant growth-promotion traits in rice. Microbiol Res., 169:40-48.

Goyal, S., S.K. Dhull, and K.K. Kapoor, 2005. Chemical and biological changes during composting of different organic wastes and assessment of compost maturity. Bioresource Technology., 96:15841591.

Graff, O., and F. Makeschin, 1980. Beeinlussung des Ertrags von Weidelgrass (Lolium muttiflorum) Ausscheidungen von Regenwurmen dreier verschiedener Arten. Pedobiologia, 20:176-180

Grappelli, A., E. Galli, and U. Tomati, 1987. Earthworm casting effect on Agaricus bisporus fructification. Agrochimica, 2:457-462

Grappelli, A., V. Tomati, E. Galli, and B. Vergari, 1985. Earthworm casting in plant propagation. Hortic. Sci., 20:874-876.

Guerrero, R.D., and L.A. Guerrero, 2006. Response of eggplant (Solanum melongena) grown in plastic containers to vermicompost and chemical fertilizer. Asia Life Sciences, 15:199-204.

Gunadi, B., C. Blount, and C.A. Edward, 2002. The growth and fecundity of Eisenia foetida (Savigny) in cattle solids pre-composted for different periods. Pedobiologia 46:15-23

Gunathilagraj K, Ravignanam T, 1996) Vermicomposting of sericulture wastes. Madras. Agric. J., 83:455-457.

Guo, L., G. Wu, C. Li, W. Liu, X. Yu, D. Cheng, and G. Jiang, 2015.Vermicomposting with maize increases agricultural benefits by 304\%. Agron. Sustain. Dev., 35: 1149-1155.

Gupta, A.K., P.K. Pankaj, and V. Upadhyava, 2008. Effect of vermicompost, farm yard manure, biofertilizer and chemical fertilizers $(\mathrm{N}, \mathrm{P}, \mathrm{K})$ on growth, yield and quality of lady's finger (Abelmoschus esculentus). Pollution Research, 27:65-68

Gupta, N., K.K. Yadav, V. Kumar, 2015. A review on status of municipal solid waste management in India. J. Environ. Sci. (China), 37: 206-217.

Hahn, H., and M. Bopp, 1968. A cytokinin test with high specificity. Planta, 83:115-118

Han, J., L. Sun, X. Dong, Z. Cai, H. Yang, Y. Wang, and W. Song, 2005. Characterization of a novel plant growth-promoting bacteria strain Delftia tsuruhatensis HR4 both as a diazotroph and a potential biocontrol agent against various pathogens. Syst. Appl. Microbiol., 28:66-76.

Hand, P., W.A. Hayes, J.C. Frankland, and J.E. Satchell, 1988. Vermicomposting of cow slurry. Pedobiologia, 31:199-209.

Haritha, D.S., K. Vijayalakshmi, J.K. Pavana, S.K. Shaheen, K. Jyothi, and R.M. Surekha, 2009. Comparative assessment in enzyme activities and microbial populations during normal and vermicomposting. J. Environ. Biol., 30:1013-1017.

Harman, G.E., 2006. Overview of mechanisms and uses of Trichoderma spp. Phytopathology 96: 190194 Hashemimajda K, Kalbasia M, Golchinb A, Shariatmadaria H, 2004) Comparison of vermicompost and composts as potting media for growth of tomatoes. J. Plant Nutr., 27:11071123.

Hartenstein, R., 1983. Assimilation by earthworm Eisenia fetida. In: Satchell JE (ed) Earthworm ecology. From Darwin to vermiculture. Chapman and Hall, London, 297-308

Hartenstein, R., E.F. Neuhauser, and D.L. Kaplan, 1979. Reproductive potential of the earthworm Eisenia foetida. Oecologia, 43:329-340.

Hashemimajd, K., M. Kalbasi, A. Golchin, and H. Shariatmadari, 2004. Comparison of vermicompost and composts as potting media for growth of tomatoes. J. Plant Nutr., 27:1107-1123.

Hassen, A., K. Belguith, N. Jedidi, A. Cherif, M. Cherif, and A. Boudabous, 2001. Microbial characterization during composting of municipal solid waste. Bioresour. Technol., 80:217-225.

Hättenschwiler, S., and P. Gasser, 2005. Soil animals alter plant litter diversity effects on decomposition. Proc. Natl. Acad. Sci. U.S.A. 102: 1519-1524. 
Haug, R.T., 1993. The practical handbook of compost engineering. Lewis Publishers, ISBN 0-87371373-7, Boca Raton, Florid.

Hawida, S., L. Kapari, V. Ossipov, M.J. Ramtala, T. Ruuhola, and E. Haukioja, 2007. Foliar phenolics are differently associated with Epirrita autmnata growth and immuno competence. J. Chem. Ecol., 33:1013-1023.

Herath, M., H. Suzanne, C.B. Joel, E.F. Ashley and L.H.Y. Elisa, 2017. The Role of the Gastrointestinal Mucus System in Intestinal Homeostasis: Implications for Neurological Disorders, Frontiers in Cellular and Infection Microbiology www.frontiersin.org, 10:248.

Herms, D.A., 2002. Effects of fertilization on insect resistance of woody ornamental plants. Environ. Entomol., 31:923-933.

Hernandez, O.L., A. Calderín, R. Huelva, D. Martínez-Balmori, F. Guridi, N.O. Aguiar, F.L. Olivares, and L.P. Canellas, 2015. Humic substances from vermicompost enhance urban lettuce production. Agron. Sustain. Dev., 35: 225-232.

Hettiarachchi, H., J.N. Meegoda, and S. Ryu, 2018. Organic Waste Buyback as a Viable Method to Enhance Sustainable Municipal Solid Waste Management in Developing Countries. Int. J. Environ. Res. Public Health, 15, 2483.

Hettiarachchi, H., N.M. Jay and R. Sohyeon, 2018. Organic Waste Buyback as a Viable Method to Enhance Sustainable Municipal Solid Waste Management in Developing Countries, Int. J. Environ. Res. Public Health, 15: 2483.

Hoitink, H.A., and M.E. Grebus, 1997. Composts and control of plant diseases. In: Hayes MHB, Wilson WS (eds) Humic substances peats and sludges health and environmental aspects. Royal Society of Chemistry, Cambridge, 359-366.

Hoitink, H.A., and G.A. Kuter, 1986. Efects of composts in growth media on soil-bome pathogens. In: Chen Y, Avnimelech Y (eds) The role of organic matter in modern agriculture. Martinus Nijhoff Publishers, Dordrecht, 289-306.

Hoitink, H.A., A.G. Stone, and D.Y. Han, 1997. Suppression of plant diseases by compost. Hortic. Sci., 32: 184-187.

Holtzclaw, K.M., and G. Sposito, 1979. Analytical properties of the soluble metal complexing fractions in sludge-soil mixtures. IV. Determination of carboxyl groups in fulvic acid. Soil Sci. Soc. Am. J. 43:318-323.

Hoornweg, D., P. Bhada-Tata, and C. Kennedy, 2013. Waste production must peak this century. Nature., 502:615- 617.

Hoornweg, D., and P. Bhata-Tata, 2012. What a Waste: A Global Review of Solid Waste Menagement; World Bank: Washington, DC, USA; ISBN 9781409406877.

Horn, M.A., A. Schramm, and H.L. Drake, 2003. The earthworm gut: an ideal habitat for ingested N2Oproducing microorganisms. Appl. Environ. Microbiol, 69:1662-1669.

Hsu, J.H., and S.L. Lo 1999. Chemical and spectroscopic analysis of organic matter transformations during composting of pig manure. Environmental Pollution, 104:189-196.

Huang, K., F. Li, Y. Wei, X. Chen, and X. Fu, 2013. Changes of bacterial and fungal community compositions during vermicomposting of vegetable wastes by Eisenia foetida. Bioresour. Technol., 150:235-241.

Hue, N.V., and J.A. Silva, 2000. Organic soil amendments for sustainable agriculture: organic sources of nitrogen, phosphorus, and potassium. In: Silva JA, Uchida R (eds) Plant nutrient management in Hawaii's soils, approaches for tropical and subtropical agriculture. College of Tropical Agriculture and Human Resources, University of Hawaii.

Huelsman, M.F., C.A. Edwards, J.L. Lawrence, and D.O. Clarke-Harris, 2000. A study of the effect of soil nitrogen levels on the incidence of insect pests and predators in Jamaican sweet potato (Ipomoea batatus) and Callaloo (Amaranthus). Proc Brighton Pest Control Conference: Pests and Diseases, 8D-13:895-900.

Imam, A., B. Mohammed, D.C. Wilson, and C.R. Cheeseman, 2008. Solid waste management in Abuja, Nigeria. Waste Manag., 28: 468-472. [CrossRef] [PubMed]

Inbal, E., and M. Feldman, 1982.The response of a hormonal mutant of common wheat to bacteria of the Azospirillium. Israel J. Bot., 31:257-263.

Inbar, Y., Y. Hadar, and Y. Chen, 1993. Recycling of cattle manure: the composting process and characterization of maturity. J. Environ. Qual., 22:857-863. 
Ismail, S.A., 1995. Earthworms in soil fertility management. In: Thampan PK (ed) Organic Agriculture, $77-100$.

Ismail, S.A., 1997. Vermicology: The biology of Earthworms. Orient Longman Limited, Chennai Jadhav AD, Talashilkar SC, Pawar AG, 1997) Influence of the conjunctive use of FYM, vermicompost andurea on growth and nutrient uptake in rice. J Maharashtra Agric. Univ., 22:249250.

Jack, A.L.H., 2011. The suppression of plant pathogens by vermicompost. In: Edwards CA, Arancon NQ, Sherman R (eds) Vermiculture technology - earthworms, organic wastes and environmental management. CRC press, Boca Raton, FL, 165-182.

Jagnow, G., 1987. Inoculation of cereal crops and forage grasses with nitrogen fixing rhizosphere bacteria: a possible cause of success and failure with regard to yield response - a review. Z Pflanzenernaehr Dueng Bodenkde, 150:361-368.

Jair, A.D., C.D. Wilian and M. Arlei, 2018. Earthworms and Nematodes: The Ecological and Functional Interactions, Earthworms - The Ecological Engineers of Soil.

Jambhekar, H., 1992. Use of earthworm as a potential source of decompose organic wastes. Proc. Nat. Sem. Org. Fmg., Coimbatore, 52-53.

James, S.W., 1991. Soil, nitrogen, phosphorous, and organic matter processing by earthworms in tall grass prairie. Ecology, 72: 2101-2109.

Jangra, M., S. Sindhu, R. Gulati, and V.K. Batra, Studies on efficacy of vermicompost for the management of Polyphagotarsonemus latus

Jannsson, R.K., and Z. Smilowitz, 1986. Influence of nitrogen on population parameters of potato insects: abundance, population growth and within-plant distribution of the green peach aphid, Myzus persicae (Homoptera: Aphididae). Environ. Entomol, 15:49-55.

Jayasinghe, B.A.T.D., and D. Parkinson, 2009. Earthworms as the vectors of actinomycetes antagonistic to litter decomposer fungi. Appl. Soil Ecol., 43:1-10.

Jenkinson, D.S., 1966. The priming action. J. Appl. Radiat. Isotopes Suppl., 199-208.

Jeyabal, A., and G. Kuppuswamy, 2001. Recycling of organic wastes for the production of vermicompost and its response in rice-legume cropping system and soil fertility. European Journal of Agronomy, 15: 153-170.

Jha, B.K., P.M. Gandhi, J. Cletus, G. Raman, and N. Sakthivel, 2009. Simultaneous phosphate solubilization potential and antifungal activity of new fluorescent pseudomonad strains, Pseudomonas aeruginosa, P. plecoglossicida and P. mosselii. W J Microbiol. Biotech, 25:573-581.

Johansson, M.E., J.M. Larsson, and G.C. Hansson, 2011. The two mucus layers of colon are organized by the MUC2 mucin, whereas the outer layer is a legislator of host-microbial interactions. Proc. Natl. Acad. Sci. U.S.A., 108(Suppl. 1), 4659-4665.

Johansson, M.E.V., and C. Hansson, 2011. Keeping bacteria at a distance. Science, 334: 182-183.

Jolly, J.M., H.M. Lappin-Scott, J.M. Anderson, and C.D. Clegg, 1993. Scanning electron microscopy of the gut microflora of two earthworms: Lumbricus terrestris and Octolasion cyaneum. Microbial. Ecol., 26:235-245.

Jones, C.G., J.H. Lawton, and M. Shachak, 1994. Organisms as ecosystem engineers. Oikos., 69:373386.

Joschko, M., H. Diestel, and O. Larink, 1989. Assessment of earthworm burrowing efficiency in compacted soil with a combination of morphological and soil physical measurements. Biol Fertil Soils, 8:191-196.

Joshi, R., J. Singh, and A.P. Vig, 2015. Vermicompost as an effective organic fertilizer and biocontrol agent: Effect on growth, yield and quality of plants. Rev. Environ. Sci. Biotechnol., 14: 137-159.

Jouquet, P., J. Dauber, J. Lagerl, P. Lavelle, and M. Lepage, 2006. Soil invertebrates as ecosystem engineers: intended and accidental effects on soil and feedback loops. Appl. Soil Ecol., 32: 153164.

Kale, R.D., 1995. Vermicomposting has a bright scope. Indian Silk 34:6-9 Karsten GR, Drake HL, (1995) Comparative assessment of the aerobic and anaerobic microfloras of earthworm guts and forest soils. Appl. Environ. Microbiol, 61:1039-1044.

Kale, R.D., and K. Bano, 1986. Field Trials with vermicompost (vee comp. E. 8. UAS) on organic fertilizers. In: Dass MC, Senapati BK, Mishra PC (eds) Proceedings of the national seminar on organic waste utilization. Sri. Artatrana. Ront, Burla, 151-157. 
Kale, R.D., and K. Bano, 1988. Earthworm cultivation and culturing techniques for the production of vee COMP83E UAS. Mysore J. Agric. Sci., 2:339-344.

Kale, R.D., B.C. Mallesh, K. Bano, and D.J. Bagyaray, 1992. Influence of vermicompost application on the available macronutrients and selected microbial populations in paddy field. Soil Biol. Biochem., 24:1317-1320.

Kalembasa, D., 1996. The influence of vermicomposts on yield and chemical composition of tomato. Zesz. Probl. Post. Nauk. Roln, 437:249-252.

Kalyani, P., B.A. New Delhi, M.J. Stout, J. Attajarusit, P. Tantasawat, 2009. Defensive role of tomato polyphenoloxidases against cotton bollworm (Helicoverpa armigera) and beet army worm (Spodoptera exigua). J. Chem. Ecol., 35:28-38.

Kaneda, S., M. Nakajima, Y. Urashima, and T. Murakami, 2014. Effectiveness of reduced tillage on the cast production of Pheretima (Amynthas) carnosa and yields of Chinese cabbage on volcanicash soil. Japan Agricultural Research Quarterly: JARQ, 48: 147-153.

Kannangowa, T., R.S. Utkhede, J.W. Paul, and Z.K. Punja, 2000. Effect of mesophilic and thermophilic composts on suppression of Fusarium root and stem rot of greenhouse cucumber. Canad. J. Microbiol., 46:1021-1022.

Karmegam, N., K. Alagermalai, and T. Daniel, 1999. Effect of vermicompost on the growth and yield of greengram (Phaseolus aureus Rob.). Trop. Agric., 76:143-146.

Karmegam, N., and T. Daniel, 2000. Effect of biodigested slurry and vermicompost on the growth and yield of cowpea (Vigna unguiculata (L.). Environ. Ecol., 18:367-370.

Karmegam, N., and T. Daniel, 2008. Effect of vermi-compost and chemical fertilizer on growth and yield of Hyacinth Bean (Lablab purpureas). Dynamic Soil, Dynamic Plant, Global Science Books, 2:77-81.

Karsten, G.R., and H.L. Drake, 1995. Comparative assessment of the aerobic and anaerobic microfloras of earthworm guts and forest soils. Appl Environ Microbiol 61:1039-1044.

Karsten GR, Drake HL, 1997) Denitrifying bacteria in the earthworm gastrointestinal tract and in vivo emission of nitrous oxide (N2O) by earthworms. Appl. Environ. Microbiol, 63:1878-1882.

Kaviraj, Sh.S., 2003. Municipal solid waste management through vermicomposting employing exotic and local species of earthworms. Bioresour. Technol., 90: 169-173.

Kerry, B., 1988. Fungal parasites of cyst nematodes. In: Edwards CA, Stinner BR, Stinner D, Rabatin S (eds) Biological Interactions in Soil. Elsevier, Amsterdam, 293-306.

Khambata, S.R., and J.V. Bhat, 1953. Studies on a new oxalate-decomposing bacterium, Pseudomonas oxalaticus. J. Bacteriol., 66:505-507.

Khodaverdiloo, H., X.H. Fengxiang, H.T. Roghaie, K. Akbar, M. Neda, and A.K. Joseph, 2020. Potentially toxic element contamination of arid and semi-arid soils and its phytoremediation, Arid. Land Research and Management, DOI: 10.1080/15324982.2020.1746707.

Knapp, B.A., S.M. Podmirseg, J. Seeber, E. Meyer, and H. Insam, 2009. Diet-related composition of the gut microbiota of Lumbricus rubellus as revealed by a molecular fingerprinting technique and cloning, Soil Biol. Biochem., 41:2299-2307.

Knuutinen, J., H. Palm, H. Hakala, J. Haimi, V. Huhta, and J. Salminen, 1990. Polychlorinated phenols and their metabolites in soil and earthworms of a saw mill environment. Chemosphere, 20:609623.

Kolodziej, M., and J. Kostecka, 1994. Some qualitative features of the cucumbers and carrots cultivated on the vermicompost. Zeszyty Naukowe Akademii Rolniczej W. Krakowie, 292:89-94.

Kooch, Y., H. Jalilvand, 2008. Earthworm as ecosystem engineers and the most important detritivors in forst soils. Pak. J. Boil. Sci., 11:819-825.

Kostecka, J., J.B. Blazej, M. Kolodziej, 1996. Investigations on application of vermicompost in potatoes farming in second year of experiment. Zeszyty Naukowe Akademii Rolniczej W. Krakowie, 310:69-77.

Kostecka, J., J.B. Blazej, and M. Kolodziej, 1996a. Investigations on application of vermicompost in potatoes farming in second year of experiment. Zeszyty Naukowe Akademii Rolniczej W Krakowie, 310:69-77.

Kostecka, J.B., 2000. Wermi komposto waniem odpadów organicznych. Zeszyty Naukowe Akademii Rolniczej w Krakowie. Rozprawy, 68:1-88. 
Koul, O., 2008. Phytochemicals and insect control: an antifeedant approach. Crit. Rev. Plant Sci., 27:124.

Kris tu"fek, V., M. Hallmann, W. Westheide, and H. Schrempf, 1995. Selection of various Streptomyces species by Enchytraeus crypticus (Oligochaeta). Pedobiologia, 39:547-554.

Kris`tu" fek, V., V. Pizl, and I.M. Szabo, 1990. Composition of the intestinal Streptomycete community of earthworms (Lumbricidae). In: Lesel R (ed) Microbiology in Poicilotherms. Elsevier, Amsterdam, 137-140.

Kris`tu"fek, V., K. Ravasz, and V. Pizi, 1993. Actinomycete communities in earthworm guts and surrounding soil. Pedobiologia, 37:379-384.

Kris `ü fek, V., K. Ravasz, and V. Pizl, 1992. Changes in densities of bacteria and microfungi during gut transit in Lumbricus rubellus and Aporrectodea caliginosa (Oligochaeta, Lumbricidae). Soil Biol. Biochem., 12:1499-1500.

Kris 'tu"fek, V., K. Tajovsky, and V. Pizi, 1994. Ultrastructural analysis of the gut content of earth worm Lubricus rubellus Hoffmeister (Annelida, Lumbricidae). Acta Microbiol. Immunol. Hung., 41: 283-290.

Krishnamoorthy, R.V., and S.N. Vajranabhaiah, 1986. Biological activity of earthworm casts: An assessment of plant growth promoter levels in the casts. Proc. Indian Acad. Sci. (Anim Sci), 95:341-351.

Krishnamoorthy, R.V., and S.N. Vajranabhiah, 1986. Biological activity of earthworm casts: An assessment of plant growth promoter levels in casts. Proc. Indian Acad. Sci., (Anim Sci) 95:34135 .

Kristufek, V., K. Ravasz, and V. Pizl, 1993. Actinomycete communities in earthworm guts and surrounding soil. Pedobiologia, 37:379-384.

Kulikova, N.A. and I.V. Perminova, 2021. Interactions between Humic Substances, Microorganisms, and Their Implications for Nature-like Bioremediation Technologies, Molecules, 26, 2706. https://doi.org/10.3390/molecules26092706

Kumar, A., 2005. Verms and vermitechnology. APH Publishing Corporation, New Delhi

Kurowska, A., J. Gora, and D. Kalemba, 1990. Effects of plant phenols on insects. Pol. Wiad. Chem., 44:399-409.

Kuter, G.A., G.B. Nelson, H.A. Hoitink, and L.V. Madden, 1983. Fungal population in container media amended with composted hardwood bark suppressive and conductive to Rhizoctonia damping-off. Phytopathology, 73:1450-1456.

Lacey, L.A., and D.I. Shapiro-Ilan, 2008. Microbial control of insect pests in temperate orchard systems: potential for incorporation into IPM. Annu. Rev. Entomol., 53:121-144.

Lal, R., and O.O. Akinremi, 1983. Physical properties of earthworm casts and surface soil influenced by management. Soil Science, 135: 114-122.

Lavelle, E., I. Barois, A. Martin, Z. Zaidi, and R. Schaefer, 1989. Management of earthworm populations in agro-ecosystems: A possible way to maintain soil quality? In: Clarholm M, Bergstrom L (eds) Ecology of Arable Land: Perspectives and Challenges. Kluwer Academic Publishers, London, 109-122.

Lavelle, P., and A. Martin, 1992. Small scale and large scale effects of endogeic earthworms in soil organic matter dynamics in soils of the humid tropics. Soil Biol. Biochem., 24:1491-1498.

Lavelle, P., 1981. Stratégies de reproduction chez les vers de terre. Acta Oecol-Oec. Gen., 2: 117-133.

Lavelle, P., 2002. Functional domains in soils. Ecol. Res. 17, 441-450.

Lavelle, P., D. Bignell, W. Heal, M. Lepage, P. Roger, and S. Dhillion, 1997. Soil function in a changing world: The role of invertebrate ecosystem engineers. European Journal of Soil Biology, 33:159193.

Lavelle, P., C. Lattaud, D. Trigo, and I. Barois, 1995. Mutualism and biodiversity in soils. Plant Soil, 170: 23-33.

Lavelle, P., A. Spain, M. Blouin, G. Brown, T. Decaëns, M. Grimaldi, et al., 2016. Ecosystem engineers in a self-organized soil: a review of concepts and future research questions. Soil Sci., 181: 91-109.

Lawton, J.H., and C.G. Jones, 1995. "Linking species and ecosystems: organisms as ecosystem engineers," in Linking Species and Ecosystems, eds C. G. Jones and J. H. Lawton (London: Chapman and Hall), 141-158. 
Lazarovits, G., M. Tenuta, K.L. Conn, M.L. Gullino, J. Katan, and A. Matta, 2000.Utilization of high nitrogen and swine manure amendments for control of soil-bome diseases: efficacy and mode of action. Acta. Hortic, 5:559-564.

Lazcano, C., M. Gomez-Brandon, and J. Domi'nguez, 2008. Comparison of the effectiveness of composting and vermicomposting for the biological stabilization of cattle manure. Chemosphere, 72:1013-1019.

Lazcano, C., M. Gomez-Brandon, and J. Dominguez, 2008. Comparison of the Effectiveness of composting and vermicomposting for the biological Stabilization of cattle manure. Chemosphere, 72: 1013-1019.

Lazcano, C., L. Sampedro, R. Zas, and J. Domínguez, 2010.Vermicompost enhances germination of the maritime pine (Pinus pinaster Ait.). New For., 39: 387-400.

Lee, K.E., 1985. Earthworms: Their Ecology and Relationships with Soils and Land Use. Academic Press, Sydney.

Lee, Y.S., and R.J. Bartlett, 1976. Stimulation of plant growth by humic substances. Soil Sci Soc Am J., 40:876-879.

Lee, K.E., 1985. Earthworms Their Ecology and Relationships with Soils and Land Use. Sydney: Academic Press Inc.

Liu, D., D. Liu, L. Liu, Y. Wang, and Y. Zhang, 2021. Screening and identification of antagonistic bacteria from vermicompost against Fusarium oxysporum f. sp. cucumerinum. Acta Agric. Scand. Sect. B Soil Plant. Sci., 71: 266-272.

Liu, F., P. Zhu, J. Xue, 2012. Comparative Study on Physical and Chemical Characteristics of Sludge Vermicomposted by Eisenia fetida. Procedia Environ. Sci., 16: 418-423.

Lon cari'c, Z., M. Engler, K. Karalic', G. Bukvic', R. Lonc`aric', and D. Kralik, 2005. Ocjena kvalitete vermikompostiranog goved ${ }^{-}$eg stajskog gnoja. Poljoprivreda, 11: 57-63.

Lores, M., M. Gómez-Brandón, D. Pérez-Díaz, and J. Domínguez, 2006. Using FAME profiles for the characterization of animal wastes and vermicomposts. Soil Biol. Biochem., 38: 2993-2996.

Lucas, P.P.B., A.Y. Caio, D.B. Clovis, A.H. Marcus, G.B. George, L.D. Harold, and M.T. Siu, 2016. Disentangling the influence of earthworms in sugarcane rhizosphere, Scientific Reports | 6:38923 | DOI: $10.1038 /$ srep38923.

Lucia, S.-P., C.L.-D. Juan, J.C.-G. Francisco and M.-M. Valentin, 2019. Sustainability Indicators Concerning Waste Management for Implementation of the Circular Economy Model on the University of Lome (Togo) Campus, Int. J. Environ. Res. Public Health 2019, 16, 2234.

Lung, A.J., C.M. Lin, J.M. Kim, M.R. Marshall, R. Nordstedt, and N.P. Thompson, et al., 2001. Destruction of Escherichia coli O157:H7 and Salmonella enteritidis in cow manure composting. Journal of Food Protection, 64: 1309-1314.

Lunt, H.A., and H.G.M. Jacobson, 1944. The chemical composition of earthworm casts. Soil Sci., 58:367-375.

Lv, B., M. Xing, and J. Yang, 2016. Speciation and transformation of heavy metals during vermicomposting of animal manure. Bioresour. Technol., 209: 397-401.

Maboeta, M.S., and L. Van Rensburg, 2003. Vermicomposting of industrially produced wood chips and sewage sludge utilizing Eisenia foetida. Ecotoxicol. Environ. Saf., 56:265-270.

Mader, P., A. Fliessbach, D. Dubois, L. Gunst, P. Fried, and U. Niggli, 2002. Soil fertility and biodiversity in organic farming. Science, 296: 1694-1697.

Madsen, E.L., and M. Alexander, 1982. Transport of Rhizobium and Pseudomonas through soil. Soil Sci. Soc. Am. J., 46:557-560.

Mahanil, S., J. Attajarusit, M.J. Stout, and P. Thipayong, 2008. Over expression of tomato phenol oxidase increases resistance to the common cutworm. Plant Sci., 174:456-466.

Mahboub, K.A., M.N. Padasht, A. Ajili Lahiji, and A. Shirinfekr, 2019. The effect of sawdust vermicompost extract on Syngonium podophyllum growth and nutrition. J. Plant. Nutr. 42: 410416.

Maheswarappa, H.P., H.V. Nanjappa, and M.R. Hegde, 1999. Influence of organic manures on yield of arrowroot, soil physico-chemical and biological properties when grown as intercrop in coconut garden. Ann. Agr. Res., 20:318-323.

Mahmoud, S.A., Z. Ramadan, E.M. Thabet, and T. Khater, 1984. Production of plant growth promoting substance rhizosphere organisms. Zentrbl. Mikrobiol, 139:227-232. 
Maity, S., S. Bhattacharya, and S. Chaudhury, 2009. Metallothionein response in earthworms Lampito mauritii (Kinberg) exposed to fly ash. Chemosphere, 77: 319-324.

Makulec, G., 2002. The role of Lumbricus rubellus Hoffm. in determining biotic and abiotic properties of peat soils. Pol. J. Ecol., 50:301-339.

Makulec, G., 2002. The role of Lumbricus rubellus Hoffm. In determining biotic and abiotic properties of peat soils. Pol. J. Ecol., 50:301-339.

Manivannan, S., M. Balamurugan, K. Parthasarathi, G. Gunasekaran, and L.S. Ranganathan, 2009. Effect of vermicompost on soil fertility and crop productivity-Beans (Phaseolus vulgaris). J. Environ. Biol., 30: 275-281.

Manoa, I.J., M.A. Horn, A. Go“ßner, C. Matthies, A. Schramm, and H.L. Drake, 2003. N2O-producing microorganisms in the gut of the earthworm Aporrectodea caliginosa are indicative of ingested soil bacteria. Appl. Environ. Microbiol, 69:1655-1661.

Marcus, A.H., S. Andreas, and L.D. Harold, 2003. The Earthworm Gut: an Ideal Habitat for Ingested N2O-Producing Microorganisms, Applied and Environmental Microbiology, 69: 1662-1669.

Marfenina, O.E., and I.A. Ishchenko, 1997. Earthworm's preference for soil microscopic fungi. Izvestiya Akademii Nauk Seriya Biologicheskaya, 4:504-506.

Marinari, S., G. Masciandaro, B. Ceccanti, and S. Grego, 2000. Influence of organic and mineral fertilisers on soil biological and physical properties. Bioresour. Technol., 72:9-17.

Marshall, R.E., and K. Farahbakhsh, 2013. Systems approaches to integrated solid waste management in developing countries. Waste Management, 33: 988-1003.

Martin, J.P., 1976. Darwin on earthworms: the formation of vegetable moulds. Bookworm Publishing, Ontario Masciandaro G, Ceccanti B, Gracia C, (1997) Soil agro-ecological management: fertigation and vermicompost treatments. Bioresour. Technol., 59:199-206.

Maruri-López, I., N.Y. Aviles-Baltazar, A. Buchala, and M. Serrano, 2019. Intra and extracellular journey of the phytohormones salicylic acid. Front. Plant. Sci., 10: 423.

Masciandaro, G., B. Ceccanti, and C. Gracia, 1997. Soil agro-ecological management: fertigation and vermicompost treatments. Bioresour. Technol., 59:199-206.

Masciandaro, G., B. Ceccanti, and C. Gracia, 2000. 'In situ' vermicomposting of biological sludges and impacts on soil quality. Soil Biol. Biochem., 32:1015-1024.

Masrat, M., and N.Z. Rehman, 2015. Resource Management through Rapid Compositing Technique: A Review, Research Journal of Agricultural Sciences, 6(4): 709-715, DI: 2341-0512-2014-182.

Maulini-Duran, C., A. Artola, X. Font, and A. Sánchez, 2014. Gaseous emissions in municipal wastes composting: Effect of the bulking agent. Bioresource Technology, 172:260-268.

Mawiyah M., A. Rosazlin and S.Y. Jamilah, 2018. Effect of Vermicompost Amendment on Nutritional Status of Sandy Loam Soil, Growth Performance, and Yield of Pineapple (Ananas comosus var. MD2) under Field Conditions, Agronomy 8, 183.

McCall, D. and J. Willumsen, 1998. Effects of nitrate, ammonium and chloride application on the yield and nitrate content of soil-grown lettuce. J. Hortic. Sci. Biotechnol., 73:698-703.

McManus, P.S., V.O. Stockwell, G.W. Sundin, and A.L. Jones, 2002. Antibiotic use in plant agriculture. Annu. Rev. Phytopathol., 40: 443-465.

Medina-Sauza, R.M., Á.-J. Marycruz, D. Alix, R. Frédérique, B. Manuel, A.G.-A. José, R.C. Carlos, G. Roger, V. Luc and B. Isabelle, 2019. Building up soil microbiota: a Review, Frontiers in Environmental Sc., 7: 81.

Medina-Sauza, R.M., M. Alvarez-Jiménez, A. Delhal, F. Reverchon, M. Blouin, J.A. Guerrero-Analco, and I. Barois, 2019. Earthworms building up soil microbiota, a review. Frontiers in Environmental Science, 7: 1-20.

Meena, R.N., Y. Singh, S.P. Singh, J.P. Singh, and K. Singh, 2007. Effect of sources and level of organic manure on yield, quality and economics of garden pea (Pisum sativam L.) in eastern uttar pradesh. Vegetable Science, 34:60-63.

Mehboob, I., M. Naveed, Z.A. Zahir, and M. Ashraf, 2012. Potential of rhizobia for sustainable production of non-legumes. In: Ashraf M, O“ ztu“"rk M, Ahmad M, Aksoy A (eds) Crop production for agricultural improvement. Springer, Netherlands, 659-704.

Merdy, P., L.T. Gharbi, and Y. Lucas, 2009. Pb, Cu and Cr interactions with soil: Sorption experiments and modelling. Colloids Surf. A Physicochemical. Eng. Asp., 347: 192-199. 
Meyer-Hoffert, U., M.W. Hornef, B.Henriques-Normark, L.G. Axelsson, T. Midtvedt, K. Putsep, et al., 2008. Secreted enteric antimicrobial activity localises to the mucus surface layer. Gut., 57: 764771.

Mikola, J., and H. Seta"la“, 1998. Productivity and trophic-level biomasses in a microbial-based soil food web. Oikos, 82:158-168.

Mitchell, A., 1997. Production of Eisenia fetida and vermicompost from feed-lot cattle manure. Soil Biol Biochem., 29:763-766.

Mitchell, A., and C.A. Edwards, 1997.The production of vermicompost using Eisenia fetida from cattle manure. Soil Biol. Biochem., 29:3-4.

Mitchell, M.J., 1978. Role of invertebrates and microorganisms in sludge decomposition. In: Hartenstein R (ed) Utilisation of soil organisms in sludge management. natural technology information services. Springfield, Virginia, 35-50.

Mitchell, M.J., S.G. Hornor, and B.I. Abrams, 1980. Decomposition of sewage sludge in drying beds and the potential role of the earthworm, Eisenia foetida. J. Environ. Qual., 9:373-378.

Mitter, E.K., T. Micaela, O. Dasiel, E.D. Kari and J.G. James, 2021. Rethinking Crop Nutrition in Times of Modern Microbiology: Innovative Biofertilizer Technologies, Frontiers, 6: 606816.

Miura, F., T. Nakamoto, S. Kaneda, S. Okano, M. Nakajima, and T. Murakami, 2008. Dynamics of soil biota at different depths under two contrasting tillage practices. Soil Biology and Biochemistry, 40: 406-414.

Monroy, F., M. Aira, and J. Domi'nguez, 2009. Reduction of total coliform numbers during vermicomposting is caused by short-term direct effects of earthworms on microorganisms and depends on the dose of application of pig slurry. Sci. Total Environ, 407:5411-5416.

Monroy, F., M. Aira, J. Domínguez, 2008. Changes in density of nematodes, protozoa and total coliforms after transit through the gut of four epigeic earthworms (Oligochaeta). Appl. Soil Ecol., 39: 127-132. [CrossRef].

Moody, S.A., M.J.I. Briones, T.G. Piearce, and J. Dighton, 1995. Selective consumption of decomposing wheat straw by earthworms. Soil Biol. Biochem., 27:1209-1213.

Moody, S.A., T.G. Piearce, and J. Dighton, 1996. Fate of some fungal spores associated with wheat straw decomposition on passage through the guts of Lumbricus terrestris and Aporrectodea longa. Soil Biol. Biochem., 28:533-537.

Mora, V., E. Bacaicoa, R. Baigorri, A.M. Zamarreño, J.M. García-Mina, and I.A.A. No, 2014. Key Regulators in the Shoot Growth Promoting Action of Humic Acid in Cucumis sativus L. J. Plant. Growth Regul, 33: 430-439.

Morikawa, C., M. Saikawa, and G.L. Barronet, 1993. Fungal predators of rotifers-a comparative study of Zoophagus, Lecophagus and Cephaliophora. Mycol. Res., 97:421-428.

Morra, L., A.D. Palumbo, M. Bilotto, P. Ovieno, and S. Ptcascia, 1998. Soil solarization: organic fertilization grafting contribute to build an integrated production system in a tomato-zucchini sequence. Colture-Protte, 27:63-70.

Morsomme, P., and M. Boutry, 2000. The plant plasma membrane H, and -ATPase: Structure, function and regulation. Biochim. Biophys. Acta Biomembr, 1465: 1-16.

Muhammad, A.A., A. Farrukh, A. Amjad, A.J. Faiz, L. Hongjie and A.D. Abdel Fattah, 2017. Transgenic Strategies for Enhancement of Nematode Resistance in Plants, Frontiers in Plant Science | www.frontiersin.org, 8: 750.

Munnoli, P.M., J.A.T. Da Silva, and B. Saroj, 2010. Dynamics of the soil-earthworm-plant relationship: a review. Dynamic soil, dynamic plant, 1-21.

Muscolo, A., F. Bovalo, F. Gionfriddo, and S. Nardi, 1999. Earthworm humic matter produces auxinlike effect on Daucus carota cell growth and nitrate metabolism. Soil Biol. Biochem., 31:13031311.

Muscolo, A., M. Felici, G. Concheri, and S. Nardi, 1993. Effect of earthworm humic substances on esterase and peroxidase activity during growth of leaf explants of Nicotiana plumbaginifolia. Biol. Fertil. Soils, 15:127-131.

Muscolo, A., M.R. Panuccio, M.R. Abenavoli, G. Concheri, and S. Nardi, 1996. Effect of molecular complexity acidity of earthworm faeces humic fractions on glutamale dehydrogenase, glutamine synthetase, and phosphoenolpyruvate carboxylase in Daucus carota II cells. Biol. Fertil. Soils, 22:83-88. 
Muscolo, A., F. Bovalo, F. Gionfriddo, and S. Nardi, 1999. Earthworm humic matter produces auxinlike effects on Daucus carota cell growth and nitrate metabolism. Soil Biol. Biochem., 31:13031311.

Muys, B., and P. Granval, 1997. Earthworms as bio-indicators of forest site quality. Soil Biol Biochem., 29:323-328.

Mylonas, V.A., and C.B. Mccants, 1980. Effects of humic and fulvic acids on growth of tobacco. I. Root initiation and elongation. Plant Soil, 54:485-490.

Nagavallemma, K.P., S.P. Wani, L. Stephane, V.V. Padmaja, C. Vineela, R.M. Babu, and K.L. Sahrawat, 2004. Vermicomposting: Recycling wastes into valuable organic fertilizer. Global Theme on Agrecosystems Report no.8. Patancheru 502324. International Crops Research Institute for the Semi-Arid Tropics, Andhra Pradesh, 20.

Nakamura, Y., 1996. Interactions between earthworms and microorganisms in biological control of plant root pathogens. Farming Jpn, 30:37-43.

Nakasone, A.K., W. Bettiol, and R.M. de Souza, 1999. The effect of water extracts of organic matter on plant pathogens. Summa Phytopathol., 25:330-335.

Nardi, S., G. Arnoldi, and G. Dell'Agnola, 1988. Release of hormone-like activities from Alloborophora rosea and Alloborophora caliginosa feces. J. Soil Sci., 68:563-657.

Nardi, S., G. Dell'Agnola, and P.M. Nuti, 1983. Humus production from farmyard wastes by vermicomposting. Proc. Int. Symp. On Agricultural and Environmental Prospects in Earthworm Farming., Rome, 87-94.

Ndegwa, P.M., S.A. Thompson, and K.C. Das, 2000. Effects of stocking density and feeding rate on vermicomposting of biosolids. Bioresour. Technol., 71:5-12.

Nechitaylo, T.Y., M.M. Yakimov, M. Godinho, K.N. Timmis, E. Belogolova, B.A. Byzov, A.V. Kurakov, D.L. Jones, and P.N. Golyshin, 2010. Effect of the earthworms Lumbricus terrestris and Aporrectodea caliginosa on bacterial diversity in soil. Microb. Ecol., 59:574-587.

Neklyudov, A.D., G.N. Fedotov and A.N. Ivankin 2006. Aerobic processing of organic waste into composts. Applied Biochemistry and Microbiology, 42(4): 341-353.

Nethra, N.N., K.V. Jayaprasad, and R.D. Kale, 1999. China aster (Callistephus chinensis (L)) cultivation using vermicompost as organic amendment. Crop Research, Hisar, 17:209-215.

Nielson, R.L., 1965. Presence of plant growth substances in earthworms demonstrated by paper chromatography and the Went pea test. Nature, 208:1113-1114.

Nieminen, M., T. Hurme, J. Mikola, K. Regina, and V. Nuutinen, 2015. Impact of earthworm Lumbricus terrestris living sites on the greenhouse gas balance of no-till arable soil. Bio geosciences, 12: 5481-5493.

Olaetxea, M., D. De Hita, C.A. Garcia, M. Fuentes, R. Baigorri, V. Mora, M. Garnica, O. Urrutia, J. Erro, A.M. Zamarreño, et al., 2018. Hypothetical framework integrating the main mechanisms involved in the promoting action of rhizospheric humic substances on plant root- and shootgrowth. Appl. Soil Ecol., 123: 521-537.

Orozco, F.H., J. Cegarra, L.M. Trujillo, and A. Roig, 1996. Vermicomposting of coffee pulp using the earthworm Eisenia fetida: effects on $\mathrm{C}$ and $\mathrm{N}$ contents and the availability of nutrients. Biol Fertil Soils, 22:162-166.

Ouda, O.K.M., S.A. Raza, A.S. Nizami, M. Rehan, R. Al-Waked, and N.E. Korres, 2016. Waste to energy potential:A case study of Saudi Arabia. Renew. Sustain. Energy Rev., 61: 328-340.

Ouellette, A.J., 2010. Paneth cells and innate mucosal immunity. Curr. Opin. Gastroenterol, 26: 547553.

Pachepsky, Y.A., A.M. Sadeghi, S.A. Bradford, D.R. Shelton, A.K. Guber, and T. Dao, 2006.Transport and fate of manure-borne pathogens: Modeling perspective. Agric. Water Manag., 86: 81-92. [CrossRef].

Padel, S., H. Rocklinsberg, and O. Schmid, 2009. The implementation of organic principles and values in the European regulation for organic food. Food Policy, 34:245-251.

Park, S.R., E.J. Cho, K.H. Yu, Y.S. Kim, J.J. Suh, and C.S. Chang, 1996. Endogenous phenoloxidase from an earthworm Lumbricus rubellus. Tongmul Hakoehi, 39:36-46.

Parle, J.N., 1963. A Microbiological Study of Earthworm Casts. J. Gen. Microbiol., 31:13-22

Parle, J.N., 1963a. Microorganisms in the intestines of earthworm. J. Gen. Microbiol., 31:1-11.

Parle, J.N., 1963b. A microbiological study of the earthworm casts. J. Gen. Microbiol., 31:13-22. 
Parthasarathi, K., and L.S. Ranganathan, 1998. Pressmud vermicast are hot spots of fungi and bacteria. Ecol. Environ. Cons., 4:81-86.

Pathma, J., N. Ayyadurai, and N. Sakthivel, 2010. Assessment of Genetic and Functional Relationship of Antagonistic Fluorescent Pseudomonads of Rice Rhizosphere by Repetitive Sequence, Protein Coding Sequence and Functional Gene Analyses. J. Microbiol., 48:715-727.

Pathma, J., K.R. Kamaraj, and N. Sakthivel, 2011a. Mechanisms of fluorescent pseudomonads that mediate biological control of phytopathogens and plant growth promotion of crop plants. In: Maheswari DK (ed) Bacteria in Agrobiology: Plant Growth Responses. Springer Verlag, Berlin, $77-105$.

Pathma, J., G.R. Rahul, K.R. Kamaraj, R. Subashri, and N. Sakthivel, 2011b. Secondary metabolite production by bacterial antagonists. Journal of Biological Control, 25:165-181.

Pathma, J., and N. Sakthivel, 2012. Microbial diversity of vermicompost bacteria that exhibit useful agricultural traits and waste management potential. Springer Plus, 1:26.

Pathma, J., and N. Sakthivel, 2013. Molecular and functional characterization of bacteria isolated from straw and goat manure based vermicompost. Appl. Soil Ecol., 70:33-47.

Patil, S.L., and M.N. Sheelavantar, 2000. Effect of moisture conservation practices, organic sources and nitrogen levels on yield, water use and root development of rabi sorghum (Sorghum bicolor (L.)) in the vertisols of semiarid tropics. Ann. Agric. Res., 21:32-36.

Patriquin, D.G., D. Baines, and A. Abboud, 1995. Diseases, pests and soil fertility. In: Cook HF, Lee HC (eds) Soil Management in Sustainable Agriculture. Wye College Press, Wye, 161-174.

Pattnaik, S., and M.V. Reddy, 2010. Heavy metals remediation from urban wastes using three species of earthworm (Eudrilus eugeniae, Eisenia fetida and Perionyx excavatus). J Environ. Che. Ecotoxicol, 3:345-356.

Pedersen, J.C., and N.B. Hendriksen, 1993. Effect of passage through the intestinal tract of detritivore earthworms (Lumbricus spp.) on the number of selected gram negative and total bacteria. Biol. Fertil. Soils, 16:227-232.

Peixoto, R.T.G., and A.I. Marochi, 1996. A influência da minhocas Pheretima sp. nas propriedades de um latossolo vermelho escuro álico e no desenvolvimento de culturas em sistema de plantio direto, Arapoti-PR. Revista Plantio Direto, 35: 23-25.

Petersen, H., and M.A. Luxton, 1982. A comparative analysis of soil fauna populations and their role in decomposition process. Oikos, 39:287-388.

Peterson, D.A., N.P. McNulty, J.L. Guruge, and J.I. Gordon, 2007. IgA response to symbiotic bacteria as a mediator of gut homeostasis. Cell Host Microbe, 2: 328-339.

Phelan, P.L., 2004. Connecting below-ground and above-ground food webs: the role of organic matter in biological buffering. In: Magadoff F, Well RR (eds) Soil Organic Matter in sustainable agriculture. CRC Press, Boca Raton, 199-226.

Phelan, P.L., K.H. Norris, and J.F. Mason, 1996. Soil management history and host preference by Ostrinia nubilatis: evidence for plant mineral balance mediating insect-plant interactions. Environ. Entom., 25:1329-1336.

Pinel, N., S.K. Davidson, and D.A. Stahl, 2008. Verminephrobacter eiseniae gen. nov., sp. nov., a nephridial symbiont of the earthworm Eisenia foetida (Savigny). Int. J. Syst. Evol. Microbiol., 58:2147-2157.

Pitt, D., E.L. Tilston, and A.C. Groenhof, R.A. Szmidt, 1998. Recycled organic materials (ROM) in the control of plant disease. Acta Hortic., 469:391-403.

Pizl, V., and A. Novokova, 1993. Interactions between microfungi and Eisenia andrei (Oligochaeta) during cattle manure vermicomposting. Pedobiologia, 47:895-899.

Plavšin, I., M. Velki, S. Ec`imovic', K. Vrandec '`ic', and J. C' osic', 2017. Inhibitory effect of earthworm coelomic fluid on growth of the plant parasitic fungus Fusarium oxysporum. Eur. J. Soil Biol., 78: 1-6.

Polyanskaya, L.M., N.I. Babkina, G.M. Zenova, and G.G. Zvyganitsev, 1996. Fate of actinomycetes in the intestinal tract of soil invertebrates fed on Streptomyces spores. Microbiology (Russ), 65: 493498.

Prakash, M., and N. Hemalatha, 2013. Dynamics of Microorganisms during vermi-stabilization of organic substrates and enhances performance of plant growth promoting rhizobacteria on black gram. Int. J. Curr. Microbiol. Appl. Sci., 2:171-187. 
Pramanik, P., G.K. Ghosh, P.K. Ghosal, and P. Banik, 2007. Changes in organic - C, N, P and K and enzyme activities in vermicompost of biodegradable organic wastes under liming and microbial inoculants. Bioresour. Technol., 98:2485-2494.

Puga-Freitas, R., and M. Blouin, 2015. A review of the effects of soil organisms on plant hormone signalling pathways. Environmental and Experimental Botany, 114: 104-116.

Puga-Freitas, R., and M. Blouin, 2015. A review of the effects of soil organisms on plant hormone signalling pathways. Environ. Exp. Bot. 114: 104-116.

QiTian, S., 2004. Research on prevention and elimination of agricultural pests by ginkgo phenols phenolic acids. Chem. Ind. For Prod., 24:83.

Qu, M., J. Chen, Q. Huang, J. Chen, Y. Xu, J. Luo, K. Wang, W. Gao, and Y. Zheng, 2018. Bioremediation of hexavalent chromium contaminated soil by a bioleaching system with weak magnetic fields. Int. Biodeterior. Biodegrad., 128: 41-47.

Raguchander, T., K. Rajappan, and R. Samiyappan, 1998. Influence of biocontrol agents and organic amendments on soybean root rot. Int. J. Trop. Agri., 16:247-252.

Ramesh, P., 2000. Effects of vermicomposts and vermicornposting on damage by sucking pests to ground nut (Arachis hypogea). Indian J. Agri. Sci., 70:334.

Rao, K.R., 2002. Induce host plant resistance in the management sucking pests of groundnut. Ann. Plant Prot. Sci., 10:45-50.

Rao, K.R., 2003. Influence of host plant nutrition on the incidence of Spodoptera litura and Helicoverpa armigera on groundnuts. Indian J. Entomol., 65:386-392.

Rao, K.R., P.A. Rao, and K.T. Rao, 2001. Influence of fertilizers and manures on the population of coccinellid beetles and spiders in groundnut ecosystem. Ann. Plant Prot. Sci., 9:43-46.

Rao, K.R., P.A. Rao, and K.T. Rao, 2001. Influence of fertilizers and manures on the population of coccinellid beetles and spiders in groundnut ecosystem. Ann. Plant Protect Sci., 9:43-46.

Ravasz, K., and L. Toth, 1990. Studies on the gut actinomycete population of Eisenia fetida (Savigny) (Oligochaeta: Lumbricidae). In: Le'sel R (ed) Microbiology in poecilotherms. Elsevier Press, Amsterdam, 141-144.

Ravasz, K., A. Zicsi, E. Contreras, and I.M. Szabo, 1987. Comparative bacteriological analyses of the faecal matter of different earthworm species. In: Proceedings of the international symposium on earthworms, symposia and monographs, Mucchi, 389-399.

Ravindra, N.P., G. Raman, N.K. Badri, N. Sakthivel, 2008. Assessment of genetic and functional diversity of phosphate solubilizing fluorescent pseudomonads isolated from rhizospheric soil. BMC Microbiol., 8:230.

Reeh, U., 1992. Influence of population densities on growth and reproduction of the earthworm Eisenia andrei on pig manure. Soil Biol. Biochem., 24:1327-1331.

Reganold, J.P., A.S. Palmer, J.C. Lockhart, and AN. Macgregor, 1993. Soil quality and financial performance on biodynamic and conventional farms in New Zealand. Science, 260:344- 349.

Regina, M.M.-S., Á.-J. Marycruz, D. Alix, R. Frédérique, B. Manuel, A.G.-A. José, R.C. Carlos, G. Roger, V. Luc and B. Isabelle, 2019. Earthworms Building up Soil Microbiota, a Review.

Ribeiro, C.F., E.H. Mizobutsi, D.G. Silva, J.C.R. Pereira, and L. Zambolim, 1998. Control of Meloidognye javanica on lettuce with organic amendments. Fitopatol Brasileira, 23:42-44.

Riffaldi, R., and R. Levi-Minzi, 1983. Osservazioni preliminari sul ruolo dell Eisenia foetida nell'umificazione del letame. Agrochimica, 27:271-274.

Rivera, A.M.C., E.R. Wright, M.V. López, and M.C. Fabrizio, 2004. Temperature and dosage dependent suppression of damping-off caused by Rhizoctonia solani in vermicompost amended nurseries of white pumpkin. Phyton., 53:131-136.

Rodriguez, J.A., E. Zavaleta, P. Sanchez, and H. Gonzalez, 2000. The effect of vermicomposts on plant nutrition, yield and incidence of root and crown rot of gerbera (Gerbera jamesonii H. Bolus). Fitopatol., 35:66-79.

Rodriguez-Kabana, R., 1986. Organic and inorganic amendments to soil as nematode suppressants. J. Nematol., 18:129-135.

Rorat, A., H. Suleiman, A. Grobelak, A. Grosser, M. Kacprzak, B. Płytycz, and F. Vandenbulcke, 2016. Interactions between sewage sludge-amended soil and earthworms - Comparison between Eisenia fetida and Eisenia andrei composting species. Environ. Sci. Pollut. Res., 23: 3026-3035. 
Roubalová, R., P. Procházková, A. Han`c, J. Dvo rák, and M. Bilej, 2020. Mutual interactions of E. andrei earthworm and pathogens during the process of vermicomposting. Environ. Sci. Pollut. Res., 27: 33429-33437. [CrossRef].

Rouelle, J., 1983. Introduction of an amoeba and Rhizobium Japonicum into the gut of Eisenia fetida (Sav.) and Lumbricus terrestris L. In: Satchel1 JE (ed) Earthworm Ecology: From Darwin to Vermiculture. Chapman and Hall, New York, 375-381.

Sabbas, T., A. Polettini, R. Pomi, T. Astrup, O. Hjelmar, P. Mostbauer, G. Cappai, G. Magel, S. Salhofer, C. Speiser, et al., 2003. Management of municipal solid waste incineration residues. Waste Manag., 23: 61-88.

Sai Shiva, K., V. Prasad, G. Davide and S. Emilio, 2018. Plant Growth Promoting and Biocontrol Activity of Streptomyces spp. as Endophytes, Int. J. Mol. Sci., 19: 952.

Sainz, M.J., M.T. Taboada-Castro, and A. Vilariño, 1998. Growth, mineral nutrition and mycorrhizal colonization of red clover and cucumber plants grown in a soil amended with composted urban wastes. Plant Soil, 205:85-92.

Saktar, W., D. Sengupta, and A. Chowdhury, 2009. Impact of pesticides use in agriculture: Their benefits and hazards. Interdiscip. Toxicol., 2: 1-12.

Sallaku, G., I. Babaj, S. Kaciu, and A. Balliu, 2009. The influence of vermicompost on plant growth characteristics of cucumber (Cucumis sativus L.) seedlings under saline conditions. J. Food Agric. Environ., 7: 869-872.

Samal, K., A. Raj Mohan, N. Chaudhary, and S. Moulick, 2019. Application of Vermi technology in waste management: A review on mechanism and performance. J. Environ. Chem. Eng., 7:103392.

Sampedro, L., and J. Domı'nguez, 2008. Stable isotope natural abundances $(\delta 13 \mathrm{C}$ and $\delta 15 \mathrm{~N})$ of the earthworm Eisenia fetida and other soil fauna living in two different vermicomposting environments. App. Soil Ecol., 38:91-99.

Sánchez-Monedero, M.A., A. Roig, C. Paredes, and M.P. Bernal, 2001. Nitrogen transformation during organic waste composting by the Rutgers system and its effects on ph, EC and maturity of the composting mixtures. Bioresour. Technol., 78:301-308.

Sarma, B.K., P. Singh, P. Susheel, and S. Harikesh, 2010. Vermicompost as Modulator of Plant Growth and Disease Suppression. Glob. Sci. Books, 4: 58-66.

Saumaya, G., R.S. Giraddi, and R.H. Patil, 2007. Utility of vermiwash for the management of thrips and mites on chilli (Capiscum annum) amended with soil organics. Karnataka J. Agric. Sci., 20:657-659

Savci, S., 2012. Investigation of Effect of Chemical Fertilizers on Environment. APCBEE Procedia, 1: 287-292.

Scheu, S., 1992. Automated measurement of the respiratory response of soil micro-compartments: active microbial biomass in earthworm faeces. Soil Biol. Biochem., 24:1113-1118.

Scheu, S., N. Schlitt, A.V. Tiunov, J.E. Newington, and H.T. Jones, 2002. Effects of the presence and community composition of earthworms on microbial community functioning. Oecologia, 133: $254-260$.

Scheuerell, S.J., D.M. Sullivan, and W.F. Mahaffee, 2005. Suppression of seedling damping-off caused by Pythium ultimum, and Rhizoctonia solani in container media amended with a diverse range of Pacific Northwest compost sources. Phytopathology, 95:306-315.

Schmidt, O., B.M. Doubre, M.H. Ryder, and K. Killman, 1997. Population dynamics of Pseudomonas corrugata 2140R LUX8 in earthworm food and in earthworm cast. Soil Biol. Biochem., 29:523528.

Scullion, J., and G.A. Ramshaw, 1988. Factors affecting surface casting behaviour in several species of earthworm. Biology and Fertility of Soils, 7: 39-45.

Sedlak, D.L., and P.G. Chan, 1997. Reduction of hexavalent chromium by ferrous iron. Geochim. Cosmochim. Acta, 61: 2185-2192.

Sembdner, G., E. Borgman, G. Schneider, H.W. Liebisch, O. Miersch, G. Adam, M. Lischewski, and K. Schieber, 1976. Biological activity of some conjugated gibberellins. Planta, 132:249-257.

Sen, B., and T.S. Chandra, 2009. Do earthworms affect dynamics of functional response and genetic structure of microbial community in a lab-scale composting system? Bioresour Technol., 100:804 811. 
Senesi, N., C. Saiz-Jimenez, and T.M. Miano, 1992. Spectroscopic characterization of metal-humic acid-like complexes of earthworm-composted organic wastes. Sci Total Environ., 117-118:111120.

Sharma, S., K. Pradhan, S. Satya, and P. Vasudevan, 2005. Potentiality of earthworms for waste management and in other uses - A Review. The Journal of American Science 1:4-16

Sharpley AN, Syers JK, 1976) Potential role of earthworm casts for the phosphorous enrichment of runoff waters. Soil Biol. Biochem., 8:341-346

Shi, Z., J. Liu, Z. Tang, Y. Zhao, and C. Wang, 2019. Vermiremediation of organically contaminated soils: Concepts, current status, and future perspectives. Appl. Soil Ecol. 147: 103377.

Shipitalo, J.M., and R. Le Bayon, 2004. "Quantifying the effects of earthworms on soil aggregation and porosity," in Earthworm Ecology, 2nd Edn., ed C. A. Edwards (Boca Raton, FL: CRC Press), 183200.

Shi-wei, Z., and H. Fu-zhen, 1991. The nitrogen uptake efficiency from $15 \mathrm{~N}$ labeled chemical fertilizer in the presence of earthworm manure (cast). In: Veeresh GK, Rajagopal D, Viraktamath CA (eds) Advances in Management and Conservation of Soil Fauna. Oxford and IBH publishing Co, New Delhi, 539-542.

Shuster, W.D., S. Subler, and E.L. McCoy, 2000. Foraging by deepburrowing earthworms degrades surface soil structure of a fluventic Hapludoll in Ohio. Soil and Tillage Research, 54: 179-189.

Siddiqui, Z.A., and I. Mahmood, 1996. Biological control of plant parasitic nematodes by fungi: a review. Bioresour. Technol., 58:229-239.

Siddiqui, Z.A., and I. Mahmood, 1999. Role of bacteria in the management of plant parasitic nematodes: a review. Bioresour. Technol., 69:167-179.

Sidhu, J., R.A. Gibbs, G.E. Ho, and I. Unkovich, 2001. The role of indigenous microorganisms in suppression of Salmonella regrowth in composted biosolids. Water Res., 35:913-920.

Simsek, E.Y., K. Haktanir, and Y. Yanar, 2009. Vermicompost suppresses Rhizoctonia solani Kühn in cucumber seedlings. J. Plant Dis. Protect, 9:15-17.

Singh, R., R.R. Sharma, S. Kumar, R.K. Gupta, and R.T. Patil, 2008. Vermicompost substitution influences growth, physiological disorders, fruit yield and quality of strawberry (Fragaria $\mathrm{x}$ ananassa Duch.). Bioresour. Technol., 99:8507-8511.

Singh, R., R.R. Sharma, S. Kumar, R.K. Gupta, and R.T. Patil, 2008. Vermicompost substitution influences growth, physiological disorders, fruit yield and quality of strawberry (Fragaria $\mathrm{x}$ ananassa Duch.). Bioresour Technol., 99:8507-8511.

Singh, U.P., S. Maurya, and D.P. Singh, 2003. Antifungal activity and induced resistance in pea by aqueous extract of vermicompost and for control of powdery mildew of pea and balsam. J. Plant Dis. Prot., 110:544-553.

Singh, U.P., S. Maurya, and D.P. Singh, 2003. Antifungal activity and induced resistance in pea by aqueous extract of vermicompost and for control of powdery mildew of pea and balsam. J Plant Dis Protect, 110:544-553.

Singleton, D.R., P.F. Hendrixb, D.C. Colemanb, and W.B. Whitmana, 2003. Identification of uncultured bacteria tightly associated with the intestine of the earthworm Lumbricus rubellus (Lumbricidae; Oligochaeta). Soil Biol. Biochem., 35:1547-1555.

Singleton, D.R., P.F. Hendrixb, D.C. Colemanb, and W.B. Whitmana, 2003. Identification of uncultured bacteria tightly associated with the intestine of the earthworm Lumbricus rubellus (Lumbricidae; Oligochaeta). Soil Biol. Biochem., 35:1547-1555.

Sinha, K., D. Valani, B. Soni, and V. Chandran, 2011. Earthworm Vermicompost: A Sustainable Alternative to Chemical Fertilizers for Organic Farming. Agriculture Issues and Policies. New York: Nova Science Publishers Inc., 71.

Sinha, R.K., S. Agarwal, K. Chauhan, and D. Valani, 2010. The wonders of earthworms and its vermicompost in farm production: Charles Darwin's 'friends of farmers', with potential to replace destructive chemical fertilizers from agriculture. Agricultural sciences, 1:76-94.

Sinha, R.K., S. Agarwal, K. Chauhan, and D. Valani, 2010. The wonders of earthworms and its vermicompost in farm production: Charles Darwin's friends of farmers, with potential to replace destructive chemical fertilizers from agriculture. The Journal of Agricultural Science. 2010; 1:7694 
Sinha, R.K., G. Bharambe, and U. Chaudhari, 2008. Sewage treatment by Verm filtration with synchronous treatment of sludge by earthworms: a low-cost sustainable technology over conventional systems with potential for decentralization. The Environmentalist, 28:409-420.

Sinha, R.K., and A. Chan, 2009. Study of emission of greenhouse gases by Brisbane households practicing different methods of composting of food \& garden wastes: aerobic, anaerobic and vermicomposting [project report].South East Queensland: Griffith University.

Sinha, R.K., S. Heart, S. Agarwal, R. Asadi, and E. Carretero, 2002.Vermiculture technology for environmental management: study of the action of the earthworms Eisenia foetida, Eudrilus euginae and Perionyx excavatus on biodegradation of some community wastes in India and Australia. The Environmentalist, 22:261-268.

Sinha, R.K., S. Herat, G. Bharambe, and A. Brahambhatt, 2010. Vermistabilization of sewage sludge (biosolids) by earthworms: Converting a potential biohazard destined for landfill disposal into a pathogen-free, nutritive and safe biofertilizer for farms. Waste Management \& Research, 28:872881.

Sinha, R.K., S. Herat, D. Valani, and K. Chauhan, 2009. Vermiculture and sustainable agriculture. AmEuras J Agric and Environ Sci, IDOSI Publication, 5:1-55.

Siomos, A., 2000. Nitrate levels in lettuce at three times during a diurnal period. J. Veget. Crop Product., $6(2): 37-42$.

Sipes, B.S., A.S. Arakaki, D.P. Schmitt, and R.T. Hamasaki, 1999. Root-knot nematode management in tropical cropping systems with organic products. J. Sustain Agr., 15:69-76.

Smith, J.L. and H.P. Collins 2007. Soil microbiology, ecology and biochemistry. (3rd Edition)., 483486.

Springett, J.O., and R. Gray, 1997. The interaction between plants roots and earthworm burrows in pasture. Soil Biology \& Biochemistry, 29: 621-625.

Sreenivas, C., S. Muralidhar, and M.S. Rao, 2000. Vermicompost, a viable component of IPNSS in nitrogen nutrition of ridge gourd. Ann. Agr. Res., 21:108-113.

Steffen, K.L., M.S. Dan, J.K. Harper, S.J. Fleischer, S.S. Mkhize, D.W. Grenoble, A.A. MacNab, and K. Fager, 1995. Evaluation of the initial season for implementation of four tomato production systems. J. Am. Soc. Hort. Sci., 120:148-156.

Stephens, P.M., and C.W. Davoren, 1997. Influence of the earthworms Aporrectodea trapezoides and A. rosea on the disease severity of Rhizoctonia solani on subterranean cloves and ryegrass. Soil Biol. Biochem., 29:511-516.

Stephens, P.M., C.W. Davoren, B.M. Doube, and M.H. Ryder, 1993. Reduced superiority of Rhizoctonia solani disease on wheat seedlings associated with the presence of the earthworm Aporrectodea trapezoids. Soil Biol. Biochem., 11:1477-1484.

Stephens, P.M., C.W. Davoren, M.H. Ryder, and B.M. Doube, 1994b. Influence of the earthworm Aporrectodea trapezoides (Lumbricidae) on the colonization of alfalfa (Medicago sativa L.) roots by Rhizobium melilotti strain LS-30R and the survival of L5-30R in soil. Biol. Fertil. Soils, 18:6370 .

Stephens, P.M., C.W. Davoren, M.H. Ryder, B.M. Doube, and R.L. Correll, 1994a. Field evidence for reduced severity of Rhizoctonia bare-patch disease of wheat, due to the presence of the earthworms Aporrectodea rosea and Aporrectodea trapezoides. Soil Biol. Biochem., 26:1495-1500

Stone, A.G., S.J. Scheurell, and H.M. Darby, 2004. Suppression of soilborne diseases in field agricultural systems: organic matter management, cover cropping and other cultural practices. In: Magdoff F, Weil (eds) Soil Organic Matter in Sustainable Agriculture. CRC Press LLC, Boca Raton, 131-177.

Subler, S., C.A. Edwards, and P.J. Metzger, 1998. Comparing vermicomposts and composts. Biocycle, 39:63-66.

Subler, S., and A.S. Kirsch, 1998. Spring dynamics of soil carbon, nitrogen, and microbial activity in earthworm middens in a notill cornfield. Biology and Fertility of Soils, 26: 243-249.

Sudhakar, K., K.C. Punnaiah, and P.V. Krishnayya, 1998. Influence of organic and inorganic fertilizers and certain insecticides on the incidence of shoot and fruit borer, Leucinodes orbonalis Guen, infesting brinjal. J. Entomol. Res., 22:283-286.

Suhane, R.K., 2007. Vermicompost. Publication of Rajendra Agriculture University, Pusa, 88. 
Summers, G., and G.W. Felton, 1994. Prooxidation effects of phenolic acids on the generalist herbivore Helicoverpa zea: potential mode of action of phenolic compounds on plant anti-herbivory chemistry. Insect. Biochem. Mol. Biol., 24:943-953.

Sunish, K.R., N. Ayyadurai, P. Pandiaraja, A.V. Reddy, Y. Venkateshwarlu, O. Prakash, and N. Sakthivel, 2005. Characterization of antifungal metabolite produced by a new strain Pseudomonas aeruginosa $\mathrm{PuPa} 3$ that exhibits broad-spectrum antifungal activity and biofertility traits. J. Appl. Microbiol., 98:145-154.

Suthar, S., 2010. Evidence of plant hormone like sub-stances in vermiwash: An ecologically safe option of synthetic chemicals for sustainable farming. J. Ecol. Eng., 36:1089-1092.

Suthar, S., and S. Singh, 2008. Vermicomposting of domestic waste by using two epigeic earthworms (Perionyx excavatus and Perionyx sansibaricus). Int. J. Evniron. Sci. and Technol., 5:99-106.

Suthar, S., 2007. Vermicomposting potential of Perionyx sansibaricus (Perrier) in different waste materials. Bioresour. Technol., 98: 1231-1237.

Suthar, S., and S. Singh, 2008. Vermicomposting of domestic waste by using two epigeic earthworms. J. Environ. Sci. Technol., 5: 99-106.

Swathi, P., K.T. Rao, and P.A. Rao, 1998. Studies on control of root-knot nematode Meloidogyne incognita in tobacco miniseries. Tobacco. Res., 1:26-30.

Szcech, M., W. Rondomanski, M.W. Brzeski, U. Smolinska, and J.F. Kotowski, 1993. Suppressive effect of a commercial earthworm compost on some root infecting pathogens of cabbage and tomato. Biol. Agric. and Hortic., 10:47-52.

Szczech, M., and U. Smolinska, 2001. Comparison of suppressiveness of vermicomposts produced from animal manures and sewage sludge against Phytophthora nicotianae Breda de Haan var. nicotiannae. J. Phytopathology, 149:77-82

Szczech, M.M., 1999. Suppressiveness of vermicomposts against fusarium wilt of tomato. J Phytopathology, 147:155-161.

Szczech, M.M., 1999. Suppressiveness of vermicompost against Fusarium wilt of tomato. J. Phytopathol., 147, and 155-161.

Tajbakhsh, J., M.A. Abdoli, G.E. Mohammadi, I. Alahdadi, and M.J. Malakouti, 2008. Trend of physico-chemical properties change in recycling spent mushroom compost through vermicomposting by epigeic earthworms Eisenia foetida and E. andrei. J. Agric. Technol., 4:185198.

Tan, K.H., and D. Tantiwiramanond, 1983. Effect of humic acids on nodulation and dry matter production of soybean, peanut, and clover. Soil Sci. Soc. Am. J., 47:1121-1124.

Tesi, R. and A. Lenzi, 1998. Controlled-released fertilizers and nitrate accumulation in lettuce (Lactuca sativa L.). Agric. Mediterranea, 128(4):313-320.

Thakuria, D., O. Schmidt, D. Finan, D. Egan, and F.M. Doohan, 2010. Gut wall bacteria of earthworms: a natural selection process. ISME J. 4: 357-366.

The World Bank, 2012. What a Waste A Global Review of Solid Waste Management; TheWorld Bank: Washington, DC, USA.

Thoden, T.C., and G.W. Korthals, 2011. Termorshuizen Organic amendments and their influences on plant-parasitic and free-living nematodes: a promising method for nematode management. Nematology, 13:133-153.

Tilak, K.V.B.R., K.K. Pal, and R. De, 2010. Microbes for sustainable agriculture. IK International Publishing House Pvt. Ltd, New Delhi, p 200 Tiwari SC, Mishra RR, 1993) Fungal abundance and diversity in earthworm casts and in undigested soil. Biol. Fertil. Soils, 16:131-134.

Tiquia, S.M., 2005. Microbiological parameters as indicators of compost maturity. J. Appl. Microbiol, 99:816-828.

Tiunov, A.V., and S. Scheu, 2000. Microfungal communities in soil litter and casts of Lumbricus terrestris (Lumbricidae): a laboratory experiment. Appl. Soil Ecol., 14:17-26.

Tiwari, S.C., B.K. Tiwari, and R.R. Mishra, 1989. Microbial populations, enzyme activities and nitrogen, phosphorous, potassium enrichment in earthworm casts and in the surrounding soil of pine apple plantation. Biol Fertil Soils, 8:178-182

Tognetti, C., F. Laos, M.J. Mazzarino, and M.T. Hernández, 2000. Composting vs. vermicomposting: A comparison of end product quality. Compos. Sci. Util., 13: 6-13. 
Tomati, U., A. Grapppelli, and E. Galli, 1987. The presence of growth regulators in earthworm worked waste. In: Bonvicini Paglioi AM, Omodeo P (eds) Earthworms. Proceedings of international symposium on earthworms, selected symposia and monographs, Union Zoologica Italian, 2, Modena, Mucchi, 423-435.

Tomati, U., A. Grapppelli, and E. Galli, 1988. The hormone-like effect of earthworm casts on plant growth. Biol. Fertil. Soils, 5:288-294.

Toyota, K., and M. Kimura, 2000. Microbial community indigenous to the earthworm Eisenia foetida. Biol. Fertil. Soils, 31:187-190.

Trevors, J.T., 1984. Dehydrogenase activity in soil. A comparison between the INT and TTC assay. Soil Biol. Biochem., 16:673-674.

Ucins, and secretory immunoglobulin, A: microbe-binding biomolecules that contribute to mucosal immunity in the human gut. Crit. Rev. Biochem. Mol. Biol. 52: 45-56.

Umesh, B., L.K. Mathur, and J.N.S. Verma, 2006. Effects of vermicomposting on microbiological flora of infected biomedical waste. ISHWM Journal, 5:28-33.

Usmani, Z., V. Kumar, P. Gupta, G. Gupta, R. Rani, and A. Chandra, 2019. Enhanced soil fertility, plant growth promotion and microbial enzymatic activities of vermicomposted fly ash. Sci. Rep., 9: 10455.

Vadiraj, B.A., D. Siddagangaiah, and S.N. Potty, 1998. Response of coriander (Coriandrum sativum L.) cultivars to graded levels of vermicompost. J. Spices Aromatic Crops, 7:141-143.

Vaishnava, S., M. Yamamoto, K.M. Severson, K.A. Ruhn, X. Yu, O. Koren, et al., 2011. The antibacterial lectin RegIIIgamma promotes the spatial segregation of microbiota and host in the intestine. Science, 334: 255-258.

Valdrighi, M.M., A. Pera, M. Agnolucci, S. Frassinetti, D. Lunardi, and G. Vallini, 1996. Effects of compost-derived humic acids on vegetable biomass production and microbial growth within a plant (Cichorium intybus) soil system: a comparative study. Agric. Ecosyst. Environ., 58:133-144

Valenzuela, O., Y. Gluadia, and S. Gallardo, 1997. Use of vermicompost as a growing medium for tomato seedlings (cv. Pltense). Revista Cientifica Agropecuaria, 1:15-21.

Van Groenigen, J., I.M. Lubbers, H.M.J. Vos, G.G. Brown, G.B. De Deyn, and K.J. van Groenigen, 2014. Earthworms increase plant production: Ameta-analysis. Scientific Reports, 4: 1-7.

Vardharajula, S., A. Shaik Zulfikar, S.S.K.P. Vurukonda, and M. Shrivastava, 2017. Plant growth promoting endophytes and their interaction with plants to alleviate abiotic stress. Curr. Biotechnol., 6: 252-263. [CrossRef].

Vaz-Moreira, I., M.E. Silva, C.M. Manaia, and O.C. Nunes, 2008. Diversity of bacterial isolates from commercial and homemade composts. Microb. Ecol., 55:714-722.

Vermi, Co. Vermicomposting technology for waste management and agriculture, 2020. An executive summary [Internet]. Avaliable from: http: // www.vermico.com/summary.htm

Vessey, J.K., 2003. Plant growth promoting rhizobacteria as biofertilizers. Plant Soil, 255:571-586.

Vijayabharathi, R., B.R. Kumari, A. Satya, V. Srinivas, A. Rathore, H.C. Sharma, and S. Gopalakrishnan, 2014. Biological activity of entomopathogenic Actinomycetes against lepidopteran insects (Noctuidae: Lepidoptera). Can. J. Plant. Sci., 94:759-769.

Vijayabharathi, R., S. Arumugam, and G. Subramaniam, 2015. Plant Growth-Promoting Microbes from Herbal Vermicompost, Springer International Publishing Switzerland.

Vinken, R., A. Schaeffer, and R. Ji, 2005. Abiotic association of soil-borne monomeric phenols with humic acids. Org. Geochem., 36:583-593.

Vitorino de Souza, M.A., G.S. Montenegro, K. Faceli, and V. Casadei, 2017. Technologies and decision support systems to aid solid-waste management: A systematic review. Waste Manag., 59: 567584.

Vivas, A., B. Moreno, S. Garcia-Rodriguez, and E. Benitez, 2009. Assessing the impact of composting and vermicomposting on bacterial community size and structure, and functional diversity of an olive-mill waste. Bioresour. Technol., 100:1319-1326.

Vogt, T., 2010. Phenylpropanoid biosynthesis. Mol. Plant., 3: 2-20.

Vongdala, N., H.D. Tran, T.D. Xuan, R. Teschke, and T.D. Khanh, 2019. Heavy metal accumulation in water, soil, and plants of municipal solid waste landfill in Vientiane, Laos. Int. J. Environ. Res. Public Health, 16: 22. 
Waleed, S.A., 2016. Cow manure composting by microbial treatment for using as potting material: An overview. Pakistan Journal of Biological Sciences, 19:1-10.

Wang, X., L. Guo-Hong, Z. Cheng-Gang, J. Xing-Lai, L. Tong, Z. Pei-Ji, L. Lian-Ming, X. Jian-Ping, A. Zhi-Qiang, Z. Xi, Q. Yue-Ke, T. Meng-Qing, X. You-Yao, M. Yi-Cheng, Y. Ze-Fen, H. XiaoWei, L. Shu-Qun, N. Xue-Mei, Y. Jin-Kui, H. Ying and Z. Ke-Qin, 2014. Bacteria can mobilize nematode-trapping fungi to kill nematodes, Nature Communications, 5:5776

Wang, L., Y. Zhang, J. Lian, J. Chao, Y. Gao, F. Yang, and L. Zhang, 2013. Impact of fly ash and phosphatic rock on metal stabilization and bioavailability during sewage sludge vermicomposting. Bioresour. Technol., 136: 281-287.

Wang, Y., W. Han, X. Wang, H. Chen, F. Zhu, X. Wang, and C. Lei, 2017. Speciation of heavy metals and bacteria in cow dung after vermicomposting by the earthworm, Eisenia fetida. Bioresour. Technol., 245, 411-418.

Webster, K.A., 2005. Vermicompost increases yield of cherries for three years after a single application. EcoResearch, South Australia.

Weltzien, H.C., 1989. Some effects of composted organic materials on plant health. Agric Ecosyst. Environ., 27:439-446.

Whalen, J.K., L. Sampedro, and T. Waheed, 2004. Quantifying surface and subsurface cast production by earthworms under controlled laboratory conditions. Biology and Fertility of Soils, 39: 287-291.

Wiedinmyer, C., R.J. Yokelson, and B.K. Gullett, 2014. Global emissions of trace gases, particulate matter, and hazardous air pollutants from open burning of domestic wast E. Environ. Sci. Technol., 48: 9523-9530.[CrossRef] [PubMed].

Wilian, C.D., H.R. Ricardo, N. Herlon, L.C.B. Marie, and G.B. George, 2020. Earthworms in Brazilian no-tillage agriculture: Current status and future challenges, Eur. J. Soil Sci., 71: 988-1005.

Wilson, D.P., and W.R. Carlile, 1989. Plant growth in potting media containing worm worked duck waste. Acta Hortic., 238:205-220.

Wright, M.A., 1972. Factors governing ingestion by the earthworm Lumbricus terrestris (L.) with special reference to apple leaves. Ann. Appl. Biol., 70:175-188.

Wu"st, P.K., M.A. Horn, and H.L. Drake, 2011. Clostridiaceae and Enterobacteriaceae as active fermenters in earthworm gut content. ISME J., 5:92-106.

Xiao, Z., M. Liu, L. Jiang, X. Chen, B.S. Griffiths, H. Li, and F. Hu, 2016. Vermicompost increases defense against root-knot nematode (Meloidogyne incognita) in tomato plants. Appl. Soil Ecol., 105: 177-186. [CrossRef]

Yardim, E.N., N.Q. Arancon, C.A. Edwards, and T.J.B.R.J. Oliver, 2006. Suppression of tomato hornworm (Manduca quinquemaculata) and cucumber beetles (Acalymma vittatum and Diabotrica undecimpunctata) populations and damage by vermicomposts. Pedobiologia, 50:23-29.

Yardim, E.N., and C.A. Edwards, 2003. Effects of organic and synthetic fertilizer sources on pest and predatory insects associated with tomatoes. Phytoparasitica, 31:324-329.

Yasir, M., Z. Aslam, S.W. Kim, S.W. Lee, C.O. Jeon, and Y.R. Chung, 2009a. Bacterial community composition and chitinase gene diversity of vermicompost with antifungal activity. Bioresour. Technol., 100:4396-4403.

Yasir, M., Z. Aslam, G.C. Song, C.O. Jeon, and Y.R. Chung, 2009b. Eiseniicola composti gen. nov., sp. nov., with antifungal activity against plant pathogenic fungi. Int. J. Sys. Evol. Microbiol., 60:268.

Yatoo, A.M., M.N. Ali, Z.A. Baba, and B. Hassan, 2021. Sustainable management of diseases and pests in crops by vermicompost and vermicompost tea. A review. Agron. Sustain. Dev., 41: 1-26. [CrossRef].

Yeates, G.W., 1981. Soil nematode populations depressed in the presence of earthworms. Pedobiologiaogia, 22:191-202.

Yeates, G.W., 1981. Soil nematode populations depressed in the presence of earthworms. Pedobiologiaogia, 22:191-202.

Zaller, J.G., 2007. Vermicompost as a substitute for peat in potting media: Effects on germination, biomass allocation, yields and fruit quality of three tomato varieties. Sci. Hort., 112:191-199.

Zandonadi, D.B., M.P. Santos, L.B. Dobbss, F.L. Olivares, L.P. Canellas, M.L. Binzel, A.L. Okorokova-Façanha, and A.R. Façanha, 2010. Nitric oxide mediates humic acids-induced root development and plasma membrane H, and -ATPase activation. Planta, 231: 1025-1036. 
Zenova, G.M., N.I. Babkina, L.M. Polyanskaya, and D.G. Zvyagintsev, 1996. Actinomycetes in the intestinal tract of soil invertebrates fed with vermicompost or litter. Microbiology, 65:360-365.

Zhang, B.G., G.T. Li, T.S. Shen, J.K. Wang, and Z. Sun, 2000. Changes in microbial biomass C, N, and $\mathrm{P}$ and enzyme activities in soil incubated with the earthworms Metaphire guillelmi or Eisenia foetida. Soil Biol. Biochem., 32:2055-2062.

Zhang, Y., Tian, Y., Hu, D., Fan, J., Shen, M., and G. Zeng, 2019. Is vermicompost the possible in situ sorbent? Immobilization of $\mathrm{Pb}, \mathrm{Cd}$ and $\mathrm{Cr}$ in sediment with sludge derived vermicompost, a column study. J. Hazard. Mater., 367: 83-90. 